Florida International University FIU Digital Commons

\title{
Character Education in a Muslim School: A Case Study of a Comprehensive Muslim School's Curricula
}

Patricia Z. Salahuddin

Florida International University, zahirah1@hotmail.com

DOI: $10.25148 /$ etd.FI1 1080803

Follow this and additional works at: https://digitalcommons.fiu.edu/etd

\section{Recommended Citation}

Salahuddin, Patricia Z., "Character Education in a Muslim School: A Case Study of a Comprehensive Muslim School's Curricula" (2011). FIU Electronic Theses and Dissertations. 453.

https://digitalcommons.fiu.edu/etd/453 


\section{FLORIDA INTERNATIONAL UNIVERSITY}

Miami, Florida

\section{CHARACTER EDUCATION IN A MUSLIM SCHOOL: A CASE STUDY OF A COMPREHENSIVE MUSLIM SCHOOL'S CURRICULA}

A dissertation submitted in partial fulfillment of the

requirements of the degree of

DOCTOR OF EDUCATION

in

CURRICULUM AND INSTRUCTION

by

Patricia Zahirah Salahuddin 
To: Dean Delia Garcia

College of Education

This dissertation, written by Patricia Zahirah Salahuddin, and entitled Character Education in a Muslim School: A Case Study of a Comprehensive Muslim School's Curricula, having been approved in respect to style and intellectual content, is referred to you for judgment.

We have read this dissertation and recommend that it be approved.

Carole Boyce Davies

Hilary Landorf

Aisha Y. Musa

Linda Spears-Bunton, Co-Major Professor

Mohammed K. Farouk, Co- Major Professor

Date of Defense: July 8, 2011

The dissertation of Patricia Zahirah Salahuddin is approved.

\begin{tabular}{c}
\hline $\begin{array}{l}\text { Dean Delia Garcia } \\
\text { College of Education }\end{array}$ \\
\hline Interim Dean Kevin O’Shea \\
University Graduate School
\end{tabular}

Florida International University, 2011 
C Copyright 2011 by Patricia Zahirah Salahuddin

All rights reserved. 


\section{DEDICATION}

In gratitude, I dedicate this project to the memory of both my parents for the moral compass they instilled in me at a very young age by teaching me that character does matter. Indeed, I bear witness. 


\section{ACKNOWLEDGMENTS}

I wish to express my eternal gratitude to God for providing me with an outstanding dissertation committee, Drs. Mohammad Farouk, Linda Spears-Bunton, Aisha Musa, Hilary Landorf and Carole Boyce Davies. Their guidance and support were paramount to the completion of this project. A special thanks to my major professor, Dr. Mohammad Farouk, who in spite of a tremendous load of duties and responsibilities added me as one more graduate student to his list of many. Yet, he patiently guided me through this process. Skillfully navigating me through uncertainties and encouraging me when the path was tunnel dark and I could not see my way. I would also like to thank Dr. Linda Spears-Bunton whose support was as in a relay race: carrying me through the first leg of the program, believing in me and encouraging me to pursue my topic; then she passed the baton on to Dr. Farouk. However, on the last leg of this race, the two of them were at my side running with me, moving me to the finish line. To Dr. Landorf, thank you for your diligence and persistence to make this dissertation a better product. To Dr. Musa, thank you for teaching me that Islam is as academically fascinating as it is spiritually. To Dr. Boyce Davies, thank you for being an intellectual role model. You showed me that academic contributions do not stop with the completion of the dissertation. To the faculty in the Office of Graduate Studies, Dr. Patricia Barbetta and Dr. Isadore Newman, thank you for your assistance and encouragement. Moreover, a special thanks and appreciation to Dr. Linda Bliss whose assistance, guidance, and encouragement, undoubtedly, went well beyond the call of duty.

I also wish to express my gratitude and appreciation to all members of the school who participated in this study for sharing their experiences with me and for their interest 
and support. I am grateful for my cohort who during the early years of the program, held my hand while we climbed the Everest of statistics, trekked through the forest of research papers and articles to reach this point. To all my relatives, friends, and colleagues who have inspired and supported me during this process, thank you. Most of all, I thank God for giving me a supportive and loving family. My husband Khalid, who among many gestures of support, read, edited, critiqued and served as a sounding board. For you, I am grateful. To my children, Khalid II, Quintera, Wali, Zainab and Mahasin, thank you for your unselfish support, patience, encouragement and prayers. When I requested your assistance, you were always ready to drop what you were doing to address my needs. Your advice and guidance was invaluable. And to my siblings, I am so grateful that God placed me with you. You exemplify the caring, loving and self-respecting character traits I found in this research. God has given me a wonderful family, immediate and extended. By virtue of God's gifts, my family, dissertation committee, relatives, friends and peers, this dissertation was completed. 


\title{
ABSTRACT OF THE DISSERTATION \\ CHARACTER EDUCATION IN A MUSLIM SCHOOL: A CASE STUDY OF A COMPREHENSIVE MUSLIM SCHOOL'S CURRICULA
}

\author{
by \\ Patricia Zahirah Salahuddin \\ Florida International University, 2011 \\ Miami, Florida
}

Professors Mohammed K. Farouk and Linda Spears-Bunton, Co-Major Professors

Deteriorating social behavior, negative media influence and violence among adolescents have given cause to pause and assess character development for the youth of this country. The purpose of this case study was to examine how a Muslim school's curricula implemented character education. This study used a qualitative single-case methodology to examine character education as it was experienced by the participants in a private Muslim school.

Data were collected from participant interviews, document analysis, and observations of classrooms, daily activities and special events. Data were analyzed to determine how character education was defined by the school, the method of delivery for the character education initiatives and the implementation of character education in this Muslim school. Analysis was based on Character Education Partnership's (CEP) Eleven Principles of Effective Character Education (2007). The results of the study revealed: (a) participants defined character education using varied traits, processes, and expected behaviors. (b) The school delivers its character education curriculum primarily through the Islamic studies division; an add-on delivery method. Still, there was evidence of 
partial integration of character education in the core courses and (c) based on CEP's Eleven Principles four were present and five were partially present in the school's character education initiatives. Findings also revealed that the school's emphasis on values, morality and spirituality was instrumental in their teaching character.

Findings suggest that if participants in the school community work together they might formulate a definition of character education based on common process and expected behavior and create a collaborative working relationship to implement a character education program. Finally, addressing the absent and partially absent elements of the eleven principles could enhance the school's character education initiatives. The study provides a process by which religious schools could examine their character education programs. The criteria used to measure the use of character education elements are transferable to other settings; however, this method of study does not allow generalization of findings. 


\section{TABLE OF CONTENTS}

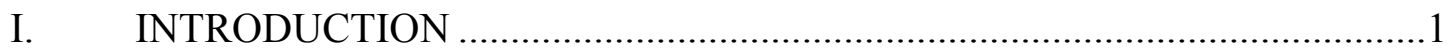

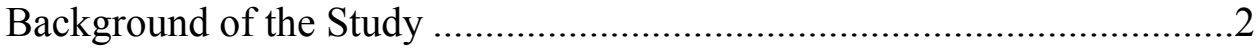

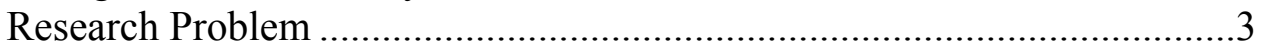

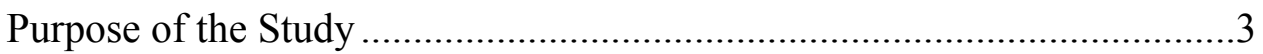

Research Questions .............................................................................

Significance of the Study .......................................................................

Theoretical Perspective ..........................................................................5

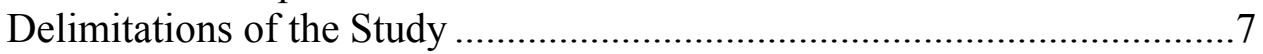

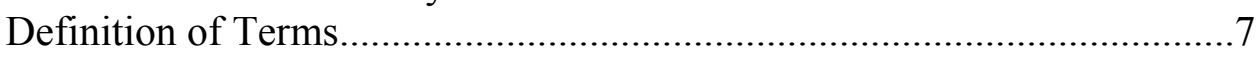

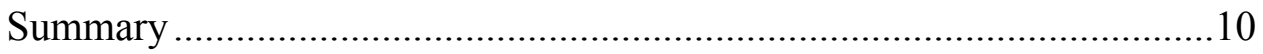

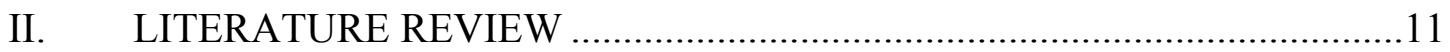

Research Questions ........................................................................11

Descriptions of Character Education .........................................................11

History of Character Education in the United States .................................16

Character Education and Diversity ..................................................18

Modernity Influences Character Education ..........................................20

Character Education in the School Curricula...........................................27

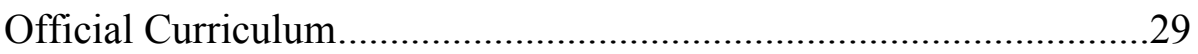

Operational Curriculum ……………………………………….........30

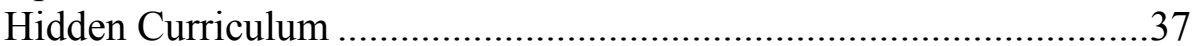

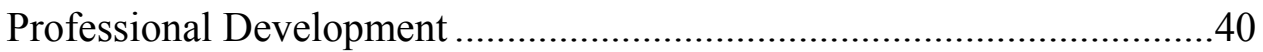

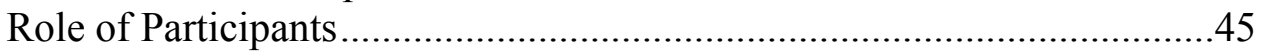

The Role of the School Leader in Character Education .......................46

The Role of Parents in Character Education .......................................50

Muslim Schools in America...................................................................53

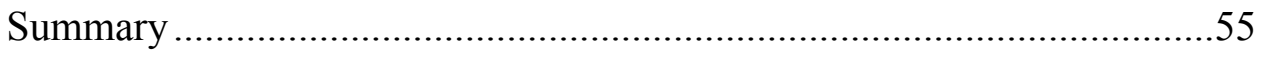

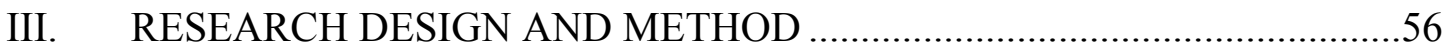

Purpose of the Study ..........................................................................56

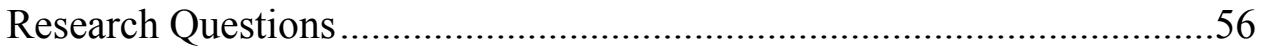

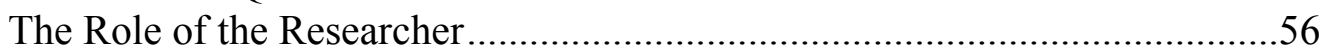

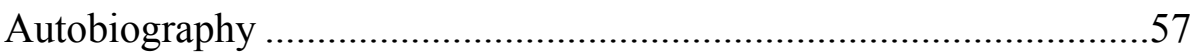

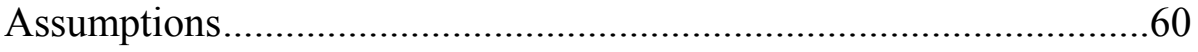

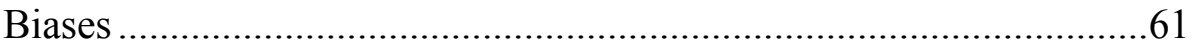

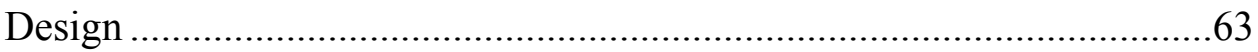

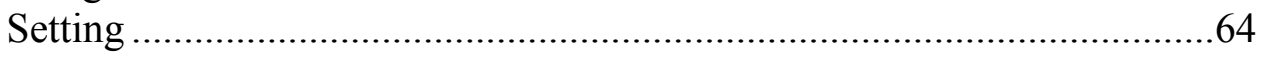

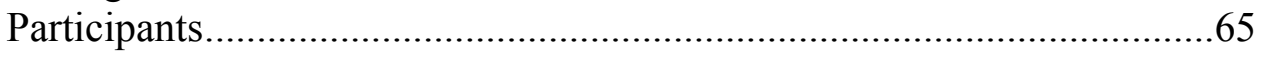

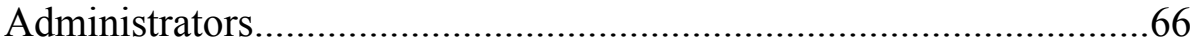

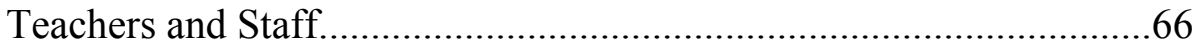




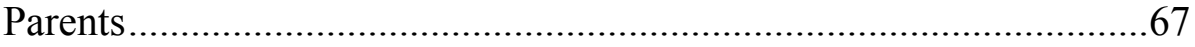

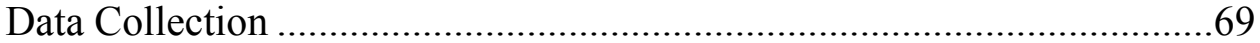

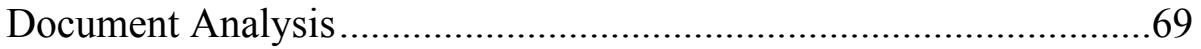

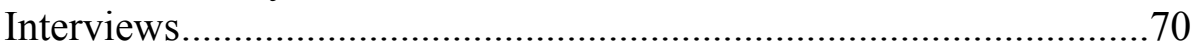

Observations ................................................................................

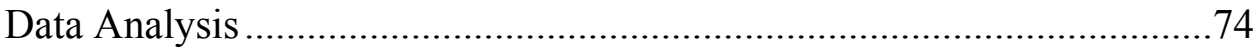

Definition of Character Education in This Muslim School ..................75

Method of Delivery of the Character Education Curriculum in

This Muslim School.........................................................................

Principles of Character Education in This

Muslim School Curricula..................................................................78

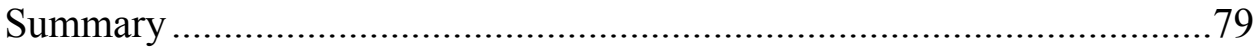

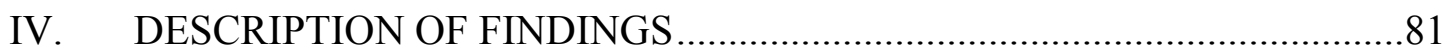

Defining Character Education at Taqwa Academy ……………………....81

Character Education Defined in Islamic Philosophy ............................82

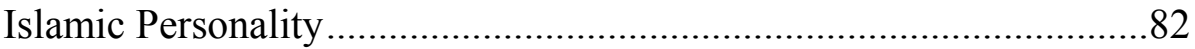

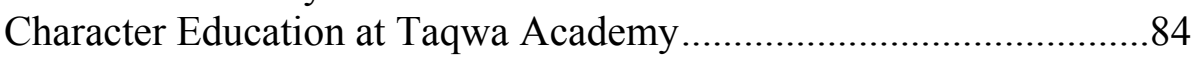

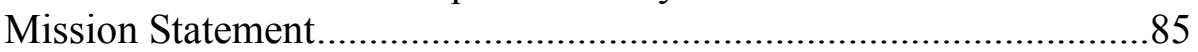

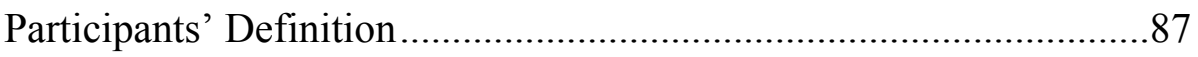

Summary of the Definition of Character

Education at Taqwa Academy .................................................................92

Method of Delivery for Character Education at Taqwa Academy ......94

The Method of Delivery: Participants' Perceptions...............................95

The Method of Delivery: Official Curriculum......................................99

Summary ……..............................................................................101

Principles of Character Education in Taqwa Academy Curricula ............102

Promotes Core Ethical Values and the Supportive Performance

Values as the Basis of Good Character................................................104

Defines "Character" Comprehensively to Include Thinking,

Feeling, and Behavior ....................................................................115

Uses Comprehensive, Intentional, and Proactive Approach to

Character Development ................................................................120

Creates a Caring School Community................................................128

Provides Students With Opportunities for Moral Actions.................132

Includes a Meaningful and Challenging Academic Curriculum.........135

Strives to Foster Students' Self-Motivation.......................................138

Engages the Staff as a Learning and Moral Community That

Shares Responsibility for Character Education ...................................140

Fosters Shared Moral Leadership and Long-Support of

Character Education Initiative

Engages Families and Community Members as Partners in the

Character-Building Effort. 
Assesses the Character of the School, the School's Staff

Functioning as Character Educators, and the Extent to Which

Students Manifest Good Character

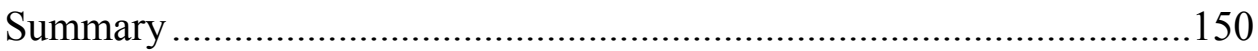

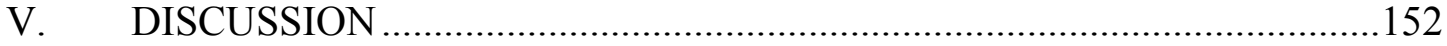

Summary of Findings...............................................................152

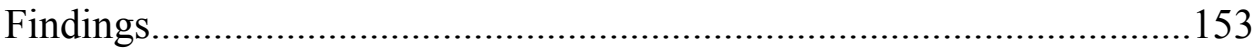

Defining Character Education..........................................................153

Method of Delivery for Character Education Curriculum at This

Muslim School .............................................................................156

Implementation of Character Education at This Muslim School

According to Character Education Partnership..................................159

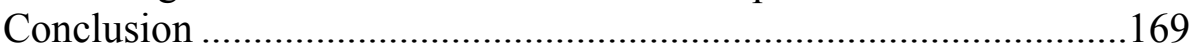

Implications for Muslim Schools...........................................................169

Defining Character Education.........................................................169

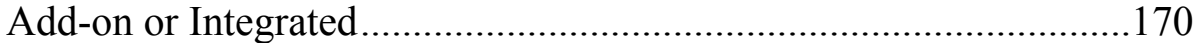

Professional Development ............................................................171

Evaluation ............................................................................

Recommendations for Further Research................................................172

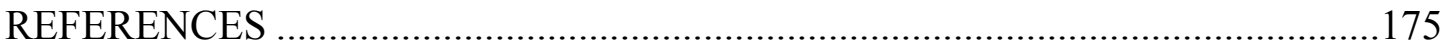

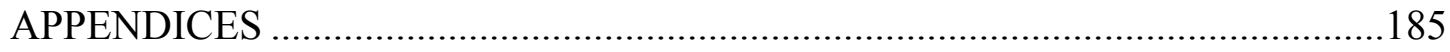

VITA 


\section{LIST OF TABLES}

TABLE

PAGE

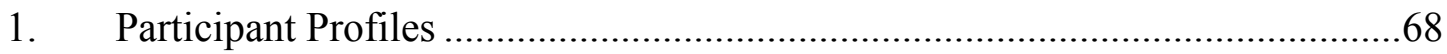

2. Participants' Language Used to Define Character Education ..........................93

3. Participants' Perspective of the Burden of

Responsibility for Character Education ..................................................97

4. Participants' Perspective of Character Education:

Added on or Integrated ...........................................................................98

5. The Character Traits Found in the Islamic Studies Curriculum

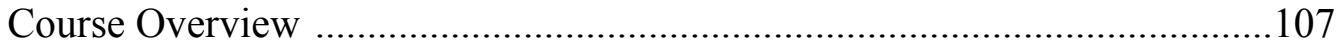

6. Character Traits Observed in the Classroom.................................................109

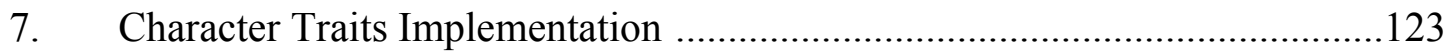

8. Pedagogical Strategies Observed During Class Observations .......................135

9. How Character Education is Implemented at Taqwa Academy.....................149 


\section{CHAPTER I}

\section{INTRODUCTION}

Educating children to adhere to the values and traditions of the society has been the underlying purpose of education in the United States (McClellan, 1999). Religion played a major role in this effort during colonial times. Parents were expected to teach their children religious lessons that were essential to growth and development as good Christians. The education of all children was focused on the moral development of the child and the Bible was the main source for these lessons, which also served as the child's reader (McClellan, 1999). However, the Bible has been replaced in the classroom with secular sources and materials.

Presently, as we move into the 21 st century, parents and educators are again concerned about the moral development of children. They are looking to schools, whether public or private, to take the lead in teaching character (McClellan, 1999). The popularity of this effort has produced many programs and approaches to character education, which has engendered a debate about which approach or program is the most effective. To address that concern researchers have published findings on different approaches to teaching character; however, most of the research has focused on public schools. Few studies have used private religious schools as the subject. No studies were located that focused on Muslim religious schools. This study of Character Education in a Muslim school is a qualitative, case study that was undertaken in order to describe how character education is implemented in a Muslim school's curricula. This chapter provided an overview of the study and how the study was conducted including the problem statement, 
research question, purpose, and significance of the study; background of the study, scope and delimitations of the study, definition of terms, researcher biases, and assumptions.

\section{Background of the Study}

Educating children for the purpose of developing children's character has been the focus of American education since the formation of the colonies (McClellan, 1999).The Puritans, an early religious group, gave parents the responsibility of giving their children an education that included learning the tenets of the religion for the purpose of developing students' character. This practice lasted until parents' views on parenting and disciplining children changed and the church leaders could no longer trust parents to train children in the "right way." As a result, leaders established educational institutions outside of the home; thus, the common schools were established (McClellan, 1999). In spite of that change, instruction remained religious; the Bible remained the source of study. In 1836, when the switch was made to the McGuffey Readers, a more secular text, stories that taught reading continued to contain moral lessons (Applebee, 1974).

After the 1830s, industrialization and modernization influenced the evolving curriculum at which time, educators turned their attention to a more scientifically developed curriculum, based more upon economic productivity rather than moral/character development; thus, the explicit study of character education was excluded. The burden of distressed family structure, urbanization, and rising crime rates in the 1960s and 1970s encouraged a new "values education." However, under heavy criticism from the question of-- "whose values?"--values education met its demise (Lickona, 1999). The current cry for character education is echoing around the nation in many school districts (Berkowitz \& Bier, 2006; Lickona, 1993). Since students attend 
private as well as public schools, it is necessary to conduct research on character education in non-public school settings; this includes religious schools. Providing educators with adequate studies to make clear decisions regarding character education requires studying character education in diverse settings.

Public schools have been the focus of most of the research regarding character education. Thus, more research conducted with religious schools is needed to determine the relationship between religions (or a belief system) and character education. Christian and Jewish schools were subjects of the few character education studies located that were conducted in religious schools. Muslim schools, relatively newcomers to the American schooling system, have had less examination on the subject of character education. In an effort to add to the information in this field of inquiry, this study was undertaken to examine how one religious school approached character education.

\section{Research Problem}

Muslim educators and parents as well as their public counterparts, are concerned about the development of students' character. There is a dearth of research on character education in Muslim schools. This study begins to fill that gap as it examined what a private Muslim school did to fulfill its mission of providing character education in the curriculum in response to the stated need to inculcate values into the students and provide a quality academic program similar to or better than programs in secular schools.

\section{Purpose of the Study}

The purpose of this study was to examine the ways in which a religious Muslim school's Pre-k to 12 curricula implement character in a South Florida community. The study also examined how the adult stakeholders (teachers, administrators, and parents) 
experienced character education, that is, the process through which it was implemented in the school's daily activities.

\section{Research Questions}

Is character education implemented at this Muslim school according to the character education framework as identified by Character Education Partnership (CEP)?

1. How is character education defined in this Muslim school?

2. What is the method of delivery for the character education curriculum in this Muslim school?

\section{Significance of the Study}

A large percentage of the student population is served by public schools; therefore, it makes sense that most studies on character education have been conducted in public school settings. However, to be comprehensive in search of effective approaches to teaching character, those in the research field must include private religious schools in the quest to understand character development. Private religious schools offer an opportunity to look at character education in a religious setting. Although this study does not explicitly pursue making a comparison of private and public schools' approach to character education, the study can be a catalyst for other studies that aim to make that comparison. Findings from the study can also stimulate questions that endeavor to determine the role that religion may play in developing character.

The role that religion may play in character education is a point of interest in the field of education. Of course, the argument that comes up in this multi-cultural society is "whose religion?" Christian and Jewish schools are the focus of a few studies on character education (Algera \& Sink, 2002; Cox \& Haney, 2002; Efron, 1996; Friedman, 
1996; Ingalls, 1999, 2002; Ingalls, \& Malkus, 2002; Simon, 1998); however, studies on character education in Muslim schools are lacking. This study was conducted in a Muslim school with the intent of making a contribution to the field of inquiry on character education in private religious schools as well as a contribution to the general literature on character education.

This studying of a Muslim school's approach to character education was undertaken to add information regarding character development and its approaches from the perspective of a non-Western culture. In his study of non-Western education, Reagan (2000) found that non-Western educational traditions shared common themes some of which are values, morality, and spirituality (Reagan, 2000). Studying a Muslim school's approach to teaching character may give insight into the role that the same themes, values, morality, and spirituality, may play in developing students' character from a different religious perspective.

This study will also benefit Muslim schools because the results of the study may give them an opportunity to review the process they are using to teach character and determine what changes, if any, they wish to be made.

\section{Theoretical Perspective}

Character education, a concept of developing moral consciousness in students (Lickona, 1999), emerges from psychological, social learning, and cognitive developmental frameworks. A review of the literature reveals a concern in finding the most efficacious approach to developing a student's character. Studies in character education have been conducted in the areas of cognitive development (Gibbs 2006; Mischel \& Mischel, 1976; Narvaez, 2001; Rest, Narvaez, Thomas, \& Bebeau, 2000); 
virtues of character (Bulach, 2002; Lickona, 1999); and social learning (Anderson, 2000; Simons \& Cleary, 2006; Wynne, 1997). The developmental approach theorizes that children develop morally in stages. This theory was developed by Lawrence Kohlberg and is similar to the model developed by Jean Piaget (Power, Higgins, \& Kohlberg, 1989). Kohlberg posited that there are six stages of moral judgment with three levels, each level containing two stages (Power et al., 1989).

Unlike the cognitive developmental approach that associates character development with moral judgment and places a child's moral growth into developmental stages, the psychological approach associates character development with virtues. The psychological perspective espoused by Lickona (1991) suggests that children can be taught character by teaching them virtues such as honesty and respect. Literature representing the psychological theory argues that virtues such as respect, responsibility, and honesty are primary elements for character development (Character Education Partnership, 2006). Yet, another theory—-the social learning theory-suggests that a child's environment plays a vital role in forming the child's character (Wynne, 1997). According to Wynne, environments include activities and opportunities intended to develop and foster character education. At some point in the discourse, these theories of cognitive, psychological and social learning, embrace virtues in some aspect. It is from these three theoretical frameworks that this discussion of character education ensued.

This is not to say that the researcher has assumed that the school under study used cognitive, psychological or social learning theory as a framework for teaching character. Instead this researcher sought the participants' definitions and descriptions of how character is implemented in this Muslim school and used the theories to better understand 
them. Thus, by examining the events in the curriculum related to character from the participants' perspectives, this study explored how character education was implemented in this Muslim school's curricula.

\section{Delimitations of the Study}

This case study examined character education as it is implemented in the curricula and experienced through daily activities by the participants of one private religious Muslim school in the United States of America. The study did not attempt to evaluate character education as it is implemented or experienced by the participants of the school.

\section{Definition of Terms}

Case study This qualitative study was a case study, which "is an empirical inquiry that investigates a contemporary phenomenon within its real-life context; when the boundaries between phenomenon and context are not clearly evident; and in which multiple sources of evidence are used" (Yin, 1989, p. 23).

Character As used in this research this term means "The inherent complex of attributes that determines a person's moral and ethical actions and reactions" (Character, 2010).

Character education As used in this research:

Character education is the intentional, proactive effort by schools, districts, and states to instill in their students important core, ethical and performance values such as caring, honesty, fairness, diligence responsibility, fortitude and respect for self and others. (Lickona, Schaps, \& Lewis, 2008) 
Current curricula Current curricula consist of all the curricula in the school including the official curriculum, the operational curriculum, extra curriculum, and the hidden curriculum.

Extra curriculum This term refers to the "non-course activities such as athletics, clubs, musical organizations, dramatics, [and competitions] that students experience at the school" (Schubert, 1986, pp.106-107).

Hadith (pl.ahadith) "Since the life time of the Prophet himself, Muslims called reports which spoke of his actions and sayings the "best hadith"'(Siddiqi,1993, p.1)

Hidden curriculum This term means "that which is taught implicitly, rather than explicitly, by the school experience" (Schubert, 1986, p.105); including beliefs, values, and the culture of the school's community. The message taught by the hidden curriculum can be "conveyed by the structures and processes of institutions and by informal learning experiences outside the institutions..." (Schubert, 1997, p. 17).

Muslim A term used to refer to those who practice the religion of Islam. It means one who submits to or obeys the laws of God as delineated in the Quran.

Muslim character As used in this study, this term refers to behavior that exhibits good manners as defined by the sunnah [the practices and traditions established by Prophet Muhammad] and the ahaadith [sayings and behaviors of the Prophet Muhammad. As described by Ali Ibn Talib, the cousin of the Prophet and fourth leader of the Muslim community:

Prophet Muhammad was generous, quiet in disposition, did not shout in public nor was he obscene and coarse. He was not revengeful unless the 
offense was against Allah and Islam. He was forgiving. He was responsible in that he cleaned his own clothes and carried out his own chores. He always stated the Name of Allah before performing any task, sitting, or standing. He was patient and showed respect to all. He spoke kindly of everyone and did not leave until the person who came to see him left. By nature he was cheerful and tender-hearted and he treated everyone as equals. (Nadwi, 1995, pp.191-192)

Muslim School Considering the stereotypes of Muslim schools generated by the media and the uninformed public, it is important to note that as used in this study, a Muslim school is defined within the context of the United States of America. It is an institution that teaches an academic curriculum similar to the curriculum taught in the United States public school system.

Official curriculum "The intended or explicit curriculum is what the schools formally admit to teaching, which includes the mission statement, statement of policy and purpose as well as skills concepts, principles and values that school provides" (Schubert, 1986, p. 104).

Operational curriculum The operational curriculum is what is actually taught in the school, which does not always coincide with the official curriculum (Schubert, 1997).

Sunnah Practices and institutions established by Prophet Muhammad, "Literally, path or example. Refers in particular to the example of the Prophet Muhammad and includes what he said, what he did and what he agreed to" (Hamid, 1989, p.182).

Taqwa Academy : The pseudonym for the school in this study. 
Values As used in this study, the term means "Sociology, the ideals, customs, institutions, etc., of a society toward which people of the group have an affective regard; any object or quality desirable as a means or as an end. To consider with respect to worth, excellence, usefulness, or importance" (Values, 2011).

Virtues or traits Qualities of good character are called virtues.... Virtues provide the moral content that defines good character. Every virtue has three parts: moral knowledge, moral feeling, moral behavior (Lickona, 1997, p. 46).

\section{Summary}

Character education is a focus of educators in both public and private schools. Studies on varying topics related to character education have been conducted in public and private schools, Muslim schools, which fall in the private school category, have been under represented in character education studies. Thus, there is a void in this research field of inquiry. This study examined how character education was implemented in a Muslim school through the current curricula. It did not attempt to evaluate how character was implemented but endeavored to describe how it was implemented and determine what was observable in the natural environment of the school's daily life. Chapter 1 provided an introduction to the study which included the background of the study, research problem, purpose, research questions, and significance of the study, theoretical perspective, delimitation, and definition of terms. Presented in the following chapters are the literature review, the method of research, the results of the study, the conclusion, and the implications. 


\section{CHAPTER II}

\section{LITERATURE REVIEW}

Schooling in America was formed for the purpose of teaching morals and good character to children (McClellan, 1999). Over the years, American educators shifted away from a moral focus in education to an academic focus. However, violent crimes in American schools and a seeming deterioration in moral behavior have parents and educators once again turning their attention to students' character development. This chapter reviews the literature on character education from the perspective of the definition, the history, character education in school curricula including the relationship between character and the various types of curricula. Professional development and the role of the character education curriculum stakeholders are also included in the literature review. Since the school in this study is a Muslim school, this section will also provide a brief history of Muslim schools in America.

\section{Research Questions}

Is character education implemented at this Muslim school according to the character education framework as identified by Character Education Partnership (CEP)?

1. How is character education defined in this Muslim school?

2. What is the method of delivery for character education curriculum in this Muslim school?

\section{Descriptions of Character Education}

Because character education is associated with various terms, it is necessary to discuss the definition from the perspective of the multiple scholars representing the three theoretical frameworks: cognitive, psychological and social domain. Whether secular or 
religious, labels and terminology used in defining character education coincide with how the definer thinks the development of character should be approached. Those who promote character education by teaching virtues, which stems from the psychological theory, (Hansen, 1995; Lickona, 1991; Stengel \& Tom, 2006) often define character by using terms describing the traits that are necessary to instill those values or virtues. For example, the leading promoter of character development through virtues, Lickona (1997) defines character education as, "the intentional, proactive effort to develop good character" (p. 46). He further elaborates that the virtues that make up good character are good for the individual and the community. Berkowitz defines it as "The intentional intervention to promote the formation of any or all aspects of moral functioning of individuals (p.2, 1998). Character Education Partnership (CEP), a leading organization of character education developed by Lickona, Schaps, and Lewis, defines character education as “...the intentional, proactive effort by schools, districts, and states to instill in their students important core ethical values such as caring, honesty, fairness, responsibility, and respect for self and others" (p.1, 2008). Other scholars define character education based on the environment and community.

Wynne (1997), a social-learning advocate of character development, posits that character education is necessary to construct environments that encourage students to practice good habits. Wynne also supports virtues referring to them as traits (p. 63). The argument for the caring community approach is led by Noddings (1997) who defines character education as "the transmittal of community values effectively to the young"(p.1). 
Kohlberg, an advocate of cognitive development, uses the term "moral education" instead of "character education." Morals, according to Kohlberg, "refer to moral judgment or decisions based on moral judgments. Moral is a judgment, not a behavior or an affect" (Kohlberg, 1980, p. 53). He also defines the goal of moral education as "the stimulation of the 'natural' development of the individual child's own moral judgment and capacities, thus allowing him to use his own moral judgment to control his behavior" (p. 72). Ryan and Bohlin (1999), advocates of virtues, define character education as a developmental process of engraving upon oneself one's own moral essence often with the help of others, requiring effort, support, knowledge, examples (good or bad) encouragement and sometimes inspiration. These scholars define character education from the perspective of the secular community and public schools. The schools in the religious communities have a specific focus in defining character education.

In religious schools, character education is defined based on religious tenets. Christian schools are concerned with developing students with "Christ-like qualities" or Christian character, or developing students who are "distinctively Christian" (Algera \& Sink, 2002; Cox \& Haney, 2002). The schools are also concerned with creating an environment "that will foster an appreciation of a student's relationship with Christ" (Algera \&Sink, 2002, p.6). These Christ-like qualities and Christian character are not explicitly defined or delineated. However, to determine if there is a possible connection to traits identified in the secular community in Christian schools, a review of character development programs used for Christian schools was conducted.

A review of eight character development programs that are designed for Christian schools identified several traits representing Christian character. Patience, diligence, 
faithfulness, and obedience were repeated in seven of the eight programs; responsibility was present in six of the programs; and honesty and forgiveness were present in five of the programs (Cox \& Haney, 2002). These terms are similar to the terms used to describe virtues listed by Lickona, Schaps, \& Lewis, (2007), in their Character Education Partnership (CEP) document. They list caring, honesty, fairness, responsibility, and respect as the core virtues for developing good character. Moreover, among these core virtues identified by CEP, honesty, caring, fairness, and respect appear in at least one of the programs as a virtue that represents Christian character. Since Christian schools promote some of the same traits found listed by the CEP, who are proponents of the virtues approach, it appears that Christian schools may be using the virtues approach to character development. Thus, the Christian character or Christ-like qualities that Christian schools use to describe what they seek to achieve with their students, support the position that character education is defined in terms reflecting the focus or objective of the participant and the method of implementation. They define character education based on the religious objective to foster Christian character or Christ-like traits in their students (Algera \& Sink, 2002). Although specific traits are not explicitly stated in the literal definition, Biblically recorded behaviors of Christ are referred to as examples of what Christians are supposed to do. The term Christ-like serves as an indicator that specific traits or behaviors are expected.

On the other hand, the language in the Jewish schools' mission statements (Charles E. Smith Jewish Day School, n.d.; Greater Boston's Jewish Day Schools, n.d.; Metrowest Jewish Day Schools, n.d.; Minneapolis Jewish Day Schools, n.d.) was slightly different from that of the Christian schools. The language in Jewish schools' mission 
statements that addresses character include terms that promote producing good people who are responsible to the community and the world. Respecting other people and recognizing the uniqueness in individuals were also stressed. The similarity between Christianity and Jewish schools is that both groups emphasize religious values. However, based on an observation of the terms referring to character development, Jewish schools stressed developing the individual to care about the community and the world, whereas, Christian schools' terms imply a focus on developing the individual to become more Christ-like. The expectation is that the child will acquire the traits that will lead him or her to exhibit the characteristic of Christ as defined in the curriculum of the school.

The language used in Muslim schools reveal a combination of values and community focus. After viewing a sampling of Muslim schools' mission statements from school websites (Al-Hamra Academy, n.d.; Crescent Academy, n.d.; Iman Academy, n.d.; Iqra Academy, n.d.; Noor Ul-Iman, n.d.), each school's mission statement stressed teaching students Islamic values and each stressed producing students with good citizenship for themselves, the community, society, and the world. Only one school (Al Hamra Academy, n.d.) listed specific values, which included quality, integrity, moderation, and teamwork. In general, Muslims define character in terms of the message brought by Prophet Muhammad.

These teachings [the message of Prophet Muhammad] show that Islam had come to illuminate the lives of the people with the light of virtue and good manners, to create in them brightness of character, and fill their laps with the pearls of good conduct. (Al-Ghazali, 2004, p.11) 
Good conduct and good manners in Islam entails being sincere, responsible, optimistic, avoiding doubtful matters, obtaining knowledge, and exhibiting kindness to Muslims and non-Muslims (At-Tahan, 1999). The terms used in the mission statements are not specific in actually defining character; therefore, an investigation of the curriculum or a program for character development in the school was needed to determine how the school defines character education and how it is implemented in the curriculum.

The literature reveals that character education is defined based on the focus and the intent of its use. Whether religious or secular, the aim is to cultivate an individual who will exhibit expected behaviors or traits. Moreover, most agree that character education is a necessary process; where they disagree is how it should be done. This debate shadows the definition offered by the different proponents of character education.

\section{History of Character Education in the United States}

This study examined the approach to character education from the perspective of Muslim schools in America. Although Muslim schools were not present in America during the formation of moral education, it is necessary to look at the context in which character education developed and evolved as we examine Muslim religious schools' approach to character education.

Although the current secular approach to developing children's character stems from religious roots, as character education traveled through time periods, it has strayed far from its religious beginnings. Historically, social, political, and economic conditions of the nation have determined the degree of interest placed on character education. Researchers have divided character education history into time periods or eras. During 
these eras, the life of character education has been contingent upon the social, political, or economic conditions of the time period (Lemmings, 2001; McClellan, 1999).

Some of the early settlers came to these shores seeking religious freedom. Groups such as the Puritans came to America to escape religious persecution in England. Although education was important to the early Americans, their purpose was strictly for developing a child's morals by learning the religion. For 143 years from 1607 to 1750 , religious groups in America including the Puritans, Protestants, and Catholics shared similar approaches to the task of developing a child's moral character. They expected the family to take the primary responsibility for educating the child with moral values, with apprenticeship, schooling, and the church serving as important supplementary institutions (McClellan, 1999).

Like most Europeans of the 17th century, Puritans assigned primary responsibility for moral education to the family, which by this point in history meant the immediate nuclear family. Laws of the Puritan colonies in New England specified that families should provide their children with an understanding of the doctrines of the faith and the laws and values of the society while also teaching then to read and to follow a useful occupation. (p. 2)

The family was the main purveyor of moral education and it remained in that position until the 19th century when common culture and traditions were threatened by an influx of immigrants who came to America with diverse religions and cultures (Leming, 2001). To address the perceived threat of anarchy and disharmony brought by the rapidly growing immigrant population, vast measures were taken. According to McClellan, "Between 1830 and 1860 Americans began to construct a vast new system of public 
schools... designed specially to be open to all white children on a roughly equal basis" (1999, p. 22). One of the noted figures responsible for the establishment of public schools is Horace Mann. In 1837 Horace Mann, a young lawyer from Massachusetts became secretary of the board created to oversee public schools in Massachusetts. Mann called this education system "Common Schools." Embracing the vast diversity of the American population, Mann sought to "use education to fashion a new American character out of a maze of conflicting cultural traditions. His tool was the common school" (Cremin, 1957, p. 8). This was an effort to produce a school system that would "Americanize" most of the school age population, thus creating a common culture.

\section{Character Education and Diversity}

To serve the increasing diverse population of students, the common schools had to make curriculum adjustments. A strong presence of immigrants and an increase in urbanization led to a decrease of religious content in schools. This increase in diversity challenged the teaching of Protestant Christian belief; thus, the public school purged the curriculum of specific religious identification and a non-sectarian Christianity was taught (Leming, 2001; McClellan, 1999). Other institutions such as after school sessions, Saturday or Sunday schools were charged with teaching the specific religious doctrine (McClellan, 1999). Most Americans accepted this type of schooling including the Jews. Although Jewish and Christian traditions are different, "Yet Jews have been strong supporters of public education. Seeing it as an avenue to opportunity and responsibility in the New World, 19th and early 20th century Jews enrolled the vast majority of their children in the public school" (McClellan, 1999, p. 42). Catholics, on the other hand, were critical of the Protestant established public school's approach to moral education. 
They believed that the Catholic catechism was the beginning of moral education and without this integration of moral and religious education; students would not get the necessary moral instruction. In Philadelphia in 1842 a conflict of which Bible—King James Bible or the Douay Bible — would be used for Bible reading mushroomed into a series of violent confrontations where more than 40 deaths occurred (McClellan, 1999). Eventually, the Catholics formed their own school system, "by the end of the 19th century the Catholic school system was firmly entrenched in virtually every part of the country" (McClellan, 1999, p. 40). Catholic schools were not willing to compromise their religion-driven curriculum for one with less religious focus.

From the late 1890s into the early 20th century, character education flourished, enjoying growth and attention by schools and communities (Mckenzie, 2004). "Children's Morality Code," a four-page brochure outlining 10 major desirable character traits, was developed and published in 1917 by William Hutchins (McClellan, 1999). The traits listed in the morality code were: self-control, kindness, self-reliance, reliability, truth, good workmanship, teamwork, duty, sportsmanship, and good health (Field, 1996; Leming, 2001; McClellan, 1999). In addition to codes, schools and communities formed children's clubs to provide opportunities for children to practice the desired virtues. It was the intent of these clubs to harness the power of peer pressure to influence children to develop good character (Field, 1996; Leming, 2001). Character educators of the 20th century

Emphasized group interaction in the educational process. Impressed both by the importance of teamwork in modern forms of production and by new psychological theories about the formation of social instincts, these educators 
expected group interactions to play a vital role in developing character.

(McClellan, 1999, p. 51)

The peer pressure approach could also work to create an undesired effect; therefore, the group interaction should be closely supervised.

\section{Modernity Influences Character Education}

Although during the 1920s character education thrived in schools and communities through character education programs, with modernity and the demand for skills efficiency and social competence, Americans became concerned with academic achievement and scientific assessment. According to McClellan (1999), in the context of the new social needs of the society, the critics of character education began to question the adequacy of the approach of moral education for the new men and women. Times were different; technological inventions had produced more leisure time. There was more time for recreation and more places to be entertained. Radio and movies promoted personal freedom and the automobile offered an opportunity to obtain it. Values were changing with the times and circumstances (McClellan, 1999). Also during this period of changing values, a study of character education programs by Harsthorne and Mays (cited in McClellan, 1999) concluded that these programs were ineffective (Field, 1996; McClellan, 1999). This conclusion sparked debate and questions. The question facing educators was what now? How do we teach morals in this rapidly developing modern society?

The escalated debate centered around three divergent views on how to approach moral education. The traditional educators promoted teaching virtues and character traits through character education programs as the best approach. They believed schools should 
be the central place to teach "specific virtues and to cultivate the traits of good character" (McClellan, 1999, p. 48). In opposition to this approach were the progressives who felt that moral education should evolve with the changing needs of society. Finally, the religious groups outside of the schools, "argued the necessity of grounding moral education in the tenets of faith and refusing to compromise with the accelerating trends toward secularization of education" (McClellan, 1999, p. 48). The complexity of the debate of how to approach developing students' character increases with the additional characters. The progressives, religious groups and groups promoting a traditional approach to character development were adamant about their perspectives.

The 1940s and 1950s brought a different attitude and softened the debate about character education. During 1940s Americans were preoccupied with events of World War II. Civic duty and responsibility were important to the American people. Therefore, the focus was on good citizenship (Field, 1996; McClellan, 1999). During this time, schools promoted character education through service to the nation. Educators gave students activities that would encourage civic responsibility and growth as well as shape character (Field, 1996; McClellan, 1999). According to Field (1996), activities that promoted civic responsibility included collecting scrap during scrap drives, and collecting war bonds and stamps. Moreover, to develop proper habits and attitudes, educational activities included lessons on morals and manners.

As World War II ended and the Cold War began, society was changing again. Implementing character education through the traditional virtue-centered method with moral codes and specific traits was challenged by the progressives (McClellan, 1999). To strike a balance between the traditional and the progressives, in 1951 the Education 
Policies Commission of the National Education Association and the American Association of School Administrators issued a report entitled "Moral and Spiritual Values in Schools"( McClellan, 1999). In spite of the compromise, there were subtle forces underway to disrupt the ease of implementing moral education programs. The demand for technical and scientific skills from the professions steered educators into a direction that was driven by an academic focused and was motivated by measurable achievement. Educators were more interested in preparing students for the expanding economy and the demands of society. Consequently, the Scholastic Aptitude Test (SAT) scores became the focus of parents who were concerned about their children attending quality universities and colleges, not their moral education (Field, 1996; McClellan, 1999). Leading into the 1960s, the emergent threat of communism, mistrust of authority, and the distinction between private and public life placed moral education in a declining position (McClellan, 1999).

During the 1960s and 1970s, moral education gasped for breath. According to McClellan (1999), the fight against racial discrimination, the protest against the Vietnam War and the growing cultural pluralism were more than enough for educators to manage. The classroom had become the stage upon which these social events were played out. Educators were very pleased to leave moral education up to the family and the church. Suspicion and distrust of the establishment and institutions made the schools a prime target for criticism. Moral education, an area of a sensitive nature where comprise and tolerance were needed, had no fertile ground to survive (McClellan, 1999). In fact, a series of Supreme Court rulings curtailed the teaching of religion in schools (McKenzie, 2004). In 1962 the Supreme Court banned school prayer and in 1963 it banned Bible 
reading. These court rulings plus others broadened the rights of children and placed moral education in public schools on the endangered list leading to possible extinction.

Educators responded to these actions by eliminating codes of conduct and only keeping those rules that were required to keep order (McClellan, 1999). The grand scale support moral education enjoyed during the 1940s and 1950s no longer existed in the 1960s.

Therefore, if character education was taught, it was taught by individual teachers and not as program supported by the school (McClellan, 1999).

However, amid the ashes of dead character education programs, in 1966 character education emerged as values clarification and the cognitive development of moral education (Field, 1996). Although the attitudes toward morals, religious privacy and acceptable behavior had changed, forces were at work to breathe life back into the ailing moral education (McClellan, 1999). The revival of moral education came in two new approaches: (a) values clarification developed by Rath, Hermin, and Simon (McClellan, 1999): and (b) cognitive development of moral education promoted by Kohlberg (McClellan, 1999; McKenzie, 2004). These two approaches, which did not impose values on children through indoctrination, fit into the social attitude of this period. Values clarification and cognitive development of moral education approaches to character education remained in existence for 20 years (Field, 1996; Leming, 2001; McKenzie, 2004). However, the strong criticism leveled by scholars on values clarification during the 1980s caused its demise (Leming, 2001). At the same time, Kohlberg's cognitive developmental moral education lost popularity because teachers found his method too difficult to implement (McKenzie, 2004). The death of values education and Kohlberg's 
cognitive development made room for the birth of "character education" as the new appellation for developing students' character.

From the 1990s to the present, moral development has returned to the stage, although not the center stage, it has earned an important position. During the 1990s the country experienced a change in language for character development; instead of "values" and "morals" it became "character education" (Leming, 2001). As a result, character education garnered an increased interest among parents and educators. Similar to the 1920s, justification for the increased concern for character development in the 1990s was a perceived increase in social problems experienced by youth and advances in psychological theory (Leming, 2001; McKenzie, 2004). Presently, some of the social problems plaguing America's youth are cheating, drug use, and crime, which has added a sense of desperation for proponents of character education. In 2006 Michael Josephson, founder and president of Josephson Institute, surveyed 36,000 high school students and reported high rates of cheating, lying, and theft among them (Josephson, 2006). The lines between right and wrong are blurred in the eyes of some students. Lately, bullying both physically and in cyberspace has led to student deaths. This is cause for alarm among educators and parents.

For proponents of character education the methodology for approaching character developed in the 1990s centered on whatever worked. They adopted any character education program that would work regardless of the school of thought from which it came (Leming, 2001; McClellan, 1999). Further in the 1990s, civic education and citizenship, closely related to character education, experienced a revival (McKenzie, 2004). Similar to the topics used by educators in the 1830 s when immigration and 
urbanization increased, educators used civics and citizenship to teach character development (Leming, 2001). Despite this relationship between character education and civic education, with the advent of No Child Left Behind, civic education has taken a lesser position in the curriculum for some schools. Civic education which is normally taught through the social studies curriculum has lost "prominence and priority in today's schools" (Hinde, p.77). The focus on high stakes assessment places emphasizes on reading and mathematics. As a result literacy and numeracy have replaced civic instructions in many school especially elementary and middle schools (Hinde, 2008). The method of teaching character education through civic education is becoming less of a reality in the 21 st century.

Consequently, moving into the 2000s educators continue to grapple over the best methods to teach character. The interest in character education has stimulated the market with many character education programs and products, from specific character development curricula to character related posters with quotes and messages for display. Consequently, there is not enough empirical data on the effectiveness of character education to support one specific character development program or method (McKenzie, 2004). Nonetheless, the debate as to which approach is the best approach to teach character development continues. Continuing tension is supported by various groups and personalities. Leading the argument for the progressive view is Purpel (1997) who accuses the proponents of character education of placing the failure of moral development on individual attitudes and behavior and ignoring the political, social, and economic failures that may contribute to the moral breakdown. He "sees traditional moral education as a neoconservative strategy...to convert social and political issues into 
educational and pedagogical ones and to focus on stability rather than transformation" (McClellan, 1999, pp.104-105). Conservative Christians believe that moral education cannot be effectively taught without including religious doctrine (McClellan, 1999). Despite these differences, moral education has begun to gain popularity and support. Consequently, school districts across the nation are turning their attention to developing students' character (Ryan \& Bohlin, 1999). "Neilsen (1998) reports 48 of the 50 states have completed or are in the process of completing state educational standards which address character education" (as cited in Milson, 2000, p. 89). That number includes the state of Florida. The two largest districts in South Florida have implemented a character education program in schools.

Reviewing the history of character education offers an overview of character education and how it has evolved to its present form. The history also reveals that the controversy and debate surrounding the best approach to gain the best results continues to exist and that political, economic and social conditions are continuing to influence those debates. Historically, the Protestant, Jewish, and Catholic faiths were participants in those debates; however, since the 20th century began, Muslim schools representing the Islamic faith have been established in the United States. These schools also seek to develop students' character. This study seeks to examine one Muslim school with the intent of answering the question of how the school's curriculum teaches character. By including the Muslim perspective, perhaps this study will broaden the knowledge base for character education and stimulate more questions and more studies of character education. 


\section{Character Education in the School Curricula}

In most schools, teaching character is implemented through the curriculum. This section of the literature review will discuss characteristics of character education programs as discussed in the literature, including the different models of implementation, and components of the curriculum as they relate to the implementation of character education. In addition, this section will also examine the literature discussion regarding the stakeholders of the curriculum, which will include the role of administrators and parents.

Character education is driven by three dominate theories: (a) cognitive developmental theory, a product of Piaget adopted by Kohlberg (1980) in developing the cognitive moral development approach; (b) the psychological theory, an approach promoted by Lickona (1991) that focuses on virtues; and (c) the social domain theory, which is also identified as social learning theory, or environmental theory, that supports the service approach promoted by Wynne (1997). As revealed by a review of the literature, curricula developed to teach character education are driven by one or more of these theories.

Research conducted on character education programs has identified content, pedagogical strategies, and elements as factors that promote the cultivation of character (Anderson, 2000; Bertowitz \& Beir, 2005; Bulach, 2002). In determining characteristics of programs that promote character education, or what works in character education, the literature reveals several recurring elements that should be present in any character education program. Programs should: (a) be integrated throughout the curriculum (Anderson, 2000; Bulach, 2002); (b) provide a social learning experience (Anderson, 
2000; Lickona, 1991; Milson, 2000; Traub, 2005; Wynne, 1997); (c) provide professional development for teachers (Anderson, 2000); (d) have professionals who exhibit character traits such as integrity, courage, trustworthiness, and compassion (Anderson, 2000; Milson, 2000); (e) have a component for parental involvement (Anderson, 2000); and (f) display a quality of implementation (Berkowitz \& Bier, 2004). Character Education Partners (CEP), a leader in promoting character education, has developed Eleven Principles of Effective Character Education (Lickona et al., 2007) to serve as a guide to teaching character:

1. Promotes core ethical values as the basis of good character

2. Defines character comprehensively to include thinking, feeling, and behavior

3. Uses a comprehensive, intentional, and proactive approach to character development

4. Creates a caring community

5. Provide students with opportunity for moral action

6. Includes a meaningful and challenging academic

7. Strives to foster students' self motivation

8. Engages school staff as a learning and moral community that shares in the responsibility for character education and attempts to adhere to the same core values

9. Foster shared moral leadership and long range support of character education initiatives 
10. Engages families and community members as partners in characterbuilding effort

11. Evaluates the character of the school, the staff and the students (pp.1-4)

Although the CEP characteristics of an effective character program are presented as principles, these principles are similar to the characteristics presented by other researchers (Berkowitz \& Bier, 2004; Ryan \& Bohlin, 1999). This indicates that agreement within the research community as to the characteristics of an effective character education program exists.

A curriculum is the vehicle by which a school reaches its goals. It represents the school's values, philosophy and culture. The curriculum itself comprises different components including the official, operational, hidden, null, and extra curricula activities (Schubert, 1986; Wilson, 2005). These components work simultaneously to meet the stated goals of the institution, which usually includes enhancing the lives of students (Schubert, 1986). It is necessary to see how character education is delivered in each component of the curriculum; thus, the following section discusses the literature review of the implementation of character as it relates to each component: the official, operational, hidden, and extra-activities curricula.

\section{Official Curriculum}

What schools overtly and explicitly admit they teach is the official curriculum (Schubert, 1986). In the official curriculum the educational institution reveals what is important and valuable to teach to students (Walker \& Soltis, 1986). The values of the school are stated in the mission statement, vision and goals and most values are understood although not explicitly stated (Schubert, 1986). Consequently, if a school is 
teaching character education, the mission statement, vision, and goals should reflect that. Muslim schools' philosophy, mission, and vision statements should emphasize the schools' focus on moral development. In addition, religious course offerings in a Muslim school should reflect moral development.

\section{Operational Curriculum}

Factors in the curriculum that facilitate character development as it relates to instructional strategies are crucial elements in the operational curriculum. Pedagogical practices for character education implemented in the classroom are explored in this section. According to Schubert (1986), factors that frame student learning include the quantity and quality of time dedicated to the task, the quality of instruction and level of objectives. A review of the literature reveals that modeling and other instructional methods are effective strategies for teaching character education (Berkowitz, \& Bier, 2004; Brogan \& Brogan, 1999; Schwartz, Beatty, \& Dachnowicz, 2005). In Muslim schools, as in most schools, instructional strategies are crucial elements for learning. Since limited literature exists on this topic for Muslim schools, this review of the literature expresses the broader view of operational curriculum.

Modeling character. In search of key elements that work in a character education curriculum, researchers found modeling as one of the essential elements in the curriculum that is effective in developing character (Berkowitz \& Bier, 2004). Modeling requires that teachers exhibit the behavior and character traits that are expected from students.

Students are keen observers of the adults in their lives. They remember more of what is seen than what is heard. Character educators posit that the "early formation of character involves education through imitation” (Brogan \& Brogan, 1999, Teaching Character- 
Based Education, para.4). Ryan and Bohlin (1999) use the term "example" to stress the importance of teacher behavior. They explain that students learn from the person not the teacher. Thus, what teachers do speaks louder than what they say (Ryan \& Bohlin, 1999). Modeling good character is an important strategy for teaching character in any setting.

To be an effective character educator, teachers must realize the vital role that they play in influencing character development. Their everyday teaching goes beyond instructional strategies. Teachers' actions have a great influence on students (Brogan \& Brogan, 1999; Hansen, 1995). In a study conducted by Benninga, Berkowitz, Kuehn, and Smith (2003) on character education implementation and academic achievement in elementary schools, the researchers reveal that effective character education programs included teachers and parents who modeled and promoted good character (as cited in Schwartz et al., 2005). In identifying elements for developing an ethical learning community, researchers and character educators Lickona and Davidson emphasized that adult role models provide significant "examples for students by exhibiting the value of striving for excellence" (as cited in Schwartz, 2005, p. 3). Thus, character education relies on adults who are exemplary at living and exhibiting the desired behavior and traits expected from students.

Literature addressing Muslim character refers to the life of Prophet Muhammad who Muslims consider to have had excellent character. Muslims as well as teachers in Muslim schools who strive to follow the traditions of Prophet Muhammad also seek to develop a character like that of the Prophet, the role model for excellent character. Actual research to determine if teachers in Muslim schools model the character traits of Prophet Muhammad was not available. 
Teaching character through stories. Teaching character through stories about heroes is a strategy employed in the operational curriculum. The literature suggests that students should receive a balanced diet of stories about heroes and historical figures who have taken the moral journey, with or without success (Ryan \& Bohlin, 1999). Literary characters may also provide moral lessons for students in helping them to identify acceptable behavior and for making decisions and judgments that will yield positive results (Ryan \& Bohlin, 1999; Sternes, 2006). Ryan and Bohlin (1999) posit that stories, plays and other literary genres provide opportunities for students to raise questions, discuss, and listen to classmates as they debate the character's choices and behaviors and determine whether the actions or choices were right or wrong. Encouraging students to make personal connection with the character allows for reflection on students' own choices and actions that they may take in a similar situation. In reviewing the literature, there are programs for teaching character education through literature. One such program is the Heartwood Institute, "An Ethics Curriculum for Children." This program was created in 1980 and piloted in the Pittsburgh city schools. It is a read-aloud, multicultural literature-based program that offers ethical content for elementary school focusing on seven virtues: courage, loyalty, respect, honesty, hope, love and justice (Stengel \& Tom, 2006). Leming (2000) conducted a study on the Heartwood Institute and concluded that there are some positive results from the program. However, to get meaningful results, literature-based character education programs should be theory-based and should have a systematic design of curriculum and instruction. Leming suggests that more analysis on data should be conducted to develop a "coherent and testable perspective on the characteristics of effective character education programmes" (Leming, 2000, p.426). 
Perhaps, if a systematic design of curriculum and instruction is developed, pre-service and in-service teachers will have a training program for teaching character education strategies.

There are ample opportunities to use literature to teach character in Muslim schools. The Qur'an, the scripture revealed to Muhammad the Prophet and used by Muslims for spiritual guidance, and the sunnah (the practices instituted by the Prophet to support Qur'anic scripture) of Prophet Muhammad and his companions, offer parables and stories about men and women who were exemplary in character as well as those who were not. The literature examining how or if Muslim schools are using these stories to develop character is not available; thus, this study seeks to explore this question in the analysis of the school's operational curriculum.

Teaching character through community service. The operational curriculum provides opportunities for students to learn character traits through service to the community. Some of the character education commercial programs incorporate a service component. Service learning, a vehicle for character education that actively involves students in addressing real community needs while allowing them to experience direct academic ties with the classroom (Otten, 2000), is a program that some schools use.

Teaching character through community service is appropriate for Muslim schools; doing good deeds, helping and caring for others are obligatory for Muslims. Shaw (2005) suggests that Muslim schools consider using the service-learning strategy to develop character because it provides hands-on experiences to what students learn in their Islamic studies classes regarding students' charity and caring for others. He supports his argument by referencing the life of Prophet Muhammad whose important aspect was 
taking care of the poor and needy as emphasized in the Qur'an (Shaw, 2005). These community service activities are also appropriate for other religious groups.

Teaching character through virtues and principles. The operational curriculum permits teaching a determined set of virtues or traits to promote good character, a common strategy schools use. Researchers such as Lickona (1997) and Benninga (1997) promote character education through virtue training. Lickona (1997) argues that the qualities of good character are virtues. Benninga (1997) posits that to teach students to become responsible citizens, time must be committed in developing traits such as persistence, temperance and civic mindedness. This approach has been criticized for its simplistic delivery such as introducing a trait of the week or month and having students to focus on that trait through various activities for that month (Sternes, 2006). Kohn (1997) argues that this method yields no lasting effect on student behavior. He also argues that this teaching strategy does not transfer to real life (as cited in Milson, 2000).

Teaching character through integration. According to Ankeney (1997), teaching character education through integration is joining together two or more content areas to teach a theme related to moral development or weaving virtue through the curriculum. Researchers list integration as an effective strategy for teaching character (Bulach, 2002; Ryan \& Bohlin, 1999; Sanchez, 2005). Rusnak (1998) lists six principles of integrated character education, which include (a) treating character as a part of every subject, (b) making character education action education, (c) creating a positive school environment, (d) establishing supportive administrative policy and practice, (e) empowering teachers, and (f) developing a partnership between school and community. 
In a Muslim school, the opportunity for teaching character through integrated units is optimized through the use of stories, in religion and literature classes. Douglass, El-Moslimany, and Uddin (2005) stress the necessity of curriculum integration in Muslim schools. They argue that because Muslim schools' mission is to infuse academic subjects with Islamic knowledge and values and the values of holistic learning based on the oneness of creation, makes it necessary to use integration as an instructional strategy. Pulling together subjects such as science, language arts, social studies and Islamic Studies in the curriculum to teach a related topic or theme enhances learning in three ways: (a) by making learning meaningful, (b) providing motivation to learn, and (c) serving as a model for implementing life (Douglass et al., 2005). The fact that these scholars are arguing the necessity for curriculum integration in Muslim schools is an indication that some Muslim schools are not using an integrated curriculum.

Teaching character through morals. The term "morals" has a religious connotation, and it was used in the earlier decades from 1600s to1980s to refer to efforts to do what is right. But by the mid-1980s the term character education became more commonly used (Stengel \&Tom, 2006). "Moral education addresses the ethical dimensions of the individual society and examines how standards of right and wrong are developed" (Otten, 2000, p. 2). Good character is the result of knowing, desiring and doing what is right (Lickona, 1991). Teaching students what is right, a matter of informing or explaining is easier than teaching them to desire and do what is right, which requires a transformation of values and views. Ryan and Bohlin (1999) suggest inspiring students, "Inspiration-moving students to become better-is the key to moral growth" (p. 
147). Teaching educators how to inspire students is the first key on the chain of keys to moral growth.

Teaching character through reflections. Ryan and Bohlin (1999) suggest using reflection to help students make meaning out of their experiences, whether personal or school related. Debating, discussing, and participating in discourse are instructional strategies teachers use to stimulate reflective and critical thinking.

Teaching character through civic duty. According to Goodlad (2004), the purpose of schooling is to prepare students to become responsible citizens. Otten (2000) defines civic education as an opportunity for active engagement in the democratic process of the school as well as the community (Otten, 2000). Teaching students to become responsible citizens is the less resistant approach to character education. To argue against teaching citizenship would be like arguing against the democratic process. Moreover Berkowitz and Althof argue that if schools are to produce moral citizens in a democratic society, they must focus on teaching civic and developing students' citizenship skills as well as character development (Althof \& Berkowitz, 2006). Character education and civic education are related in that civic education is a method by which character education can be taught. Both civic and character education have a role in preparing students to function in a democratic society.

In summary, the operational curriculum is where pedagogical strategies for character education are executed. The literature review revealed several pedagogical strategies that are effective for teaching character education. An investigation of websites of Muslim schools revealed that the schools reviewed have mission statements and visions that reflect a concern for students' character development. However, until sample 
schools' curricula are examined, empirically, it cannot be determined if Muslim schools are implementing any of the strategies revealed in the literature. Knowing whether these strategies are implemented will provide a partial answer to how character education is implemented in the curriculum. This study examined a Muslim school's curriculum for its use of pedagogical strategies to teach character as discussed in the literature.

The operational curriculum implements the policies and procedures of the official curriculum. A not so visible curriculum, the hidden curriculum, working behind the scene wields a strong influence on the learning experience of students.

\section{Hidden Curriculum}

Although the hidden curriculum is defined as knowledge students learn implicitly from the school experience including the beliefs, values and the culture of the school's community (Schubert, 1986), the aspects of the hidden curriculum that influence students' learning experiences varies. The hidden curriculum can be negative or positive; it may manifest itself through various features of the school experience such as structural, teacher's attitude, class schedule and others. Schugurensky (2002) argues that the messages received from the hidden curriculum may support or contradict the prescribed or official curriculum; the message may be positive or negative. For example, a curriculum may promote democracy; however, if the teachers' behavior and attitude or the school's climate is highly authoritarian, then the intended lesson of democracy becomes distorted. Other scholars (Wilson, 2005; Wren, 1999) also argue that students may receive both negative and positive messages from the hidden curriculum. For example, Wilson (2005) asserts that students receive positive and negative lessons from the organization of subjects, time allotments for instructions and recreation as well as 
from discipline. Wren (1999) cites the Mennonites' passing on religious faith as well as actively involving students in community issues as a positive aspect of the hidden curriculum. An example of the negative impact of the hidden curriculum is noted by Jackson (1968) who states, “...discipline problems may occur for students who have difficulty following and internalizing classroom rules and daily routines" (as cited by Wren, 1999, p. 594). Students who have those issues are usually referred to the counselors who in turn seek special intervention for this inability to follow direction. One should not avoid rules and daily routines because a student might have difficulty following directions.

According to Wilson (2005), the hidden curriculum teaches lessons that students learned through their experience with the structure of classrooms, the scheduling of classes and the attitude and behavior of teachers and administration. Ahwee, Chiappone, and Cuevas (2004) discuss how the hidden curriculum can realize itself in the architecture of the school, the gender expectations (classes and courses specifically for male or female), and student assessment. According to their experience, locating a class of disabled students in a portable a great distance from the main building and its resources sends a message of exclusion for students with disabilities. The physical structure of the school can emphasize or de-emphasize the importance of a particular subject or program of a school. In regard to gender, the hidden curriculum can indicate which courses girls and boys are expected to take. Girls may be expected to take more of the liberal arts type of courses, whereas boys may be encouraged to pursue science and math. Any student daring to venture beyond the unmarked boundaries set by tradition or culture may meet with disapproval from teachers and peers. This was the case with Peggy 
Cuevas who declared a major in economics and experienced being ignored by her professors during discussions as well as when she had questions and her "ideas and views were never solicited"(Ahwee et al., 2004, p. 28). Through the hidden curriculum students learn that certain courses or fields of study are determined by the gender, not the scholarship or interest of the student.

In addition to the architecture and gender, Ahwee et al. (2004) espouses the idea that the hidden curriculum can manifest itself through assessment. Most states mandate a high-stakes test where students are tested on specific skills. To assure that students will pass the high-stakes test, they are often required to take courses they would not normally take such as extra reading, math, and writing classes. For example, according to Ahwee et al., special education students in the southeastern United States were given an extra year of math before taking the state test. Thus, the school made the assumption that the special education students could not pass the test without the intensive training (Ahwee et al., 2004). Ahwee et al.'s experience demonstrates how the hidden curriculum can be built into the process of assessment... "[and] can drive the curriculum and the educational outcomes of the students" (p. 31). Critically important, the assessment process determines what is valued. Students will judge what is worthy of knowing based on what is assessed and will place their efforts for acquiring knowledge accordingly. Therefore, that which is not assessed is valued less. Consequently, given our emphasis on formal tests and grades, the hidden curriculum may value achievement over learning, (p. 31). The hidden curriculum can manifest in various aspects to influence the learning experiences of students including, but not limited to, the physical structure of the school, gender expectations, and the emphasis on assessment. All of these aspects indicate the value 
placed on character development. Character education is valued in the school if quality assessment is assigned, if it is integrated into the students' learning experience, and if character education is an aspect of the cultural traditions and beliefs transmitted to the next generation.

If the curriculum is the vehicle by which a school reaches its educational goals, then the teacher is the driver of that vehicle. The previous discussion of the various curricula through which character education is taught is not complete without the professionals that implement them. The following section discusses teacher preparation and in- service for character education.

\section{Professional Development}

The curriculum entails not only strategies for delivering instructions; it also addresses developing the professionals who deliver instructions. Preparing teachers to teach character is a key element of a curriculum designed to teach character. The literature reviewed on this topic is very specific about the importance of this element of the curriculum.

Teachers will ultimately make the difference in the implementation of a character education program (Silva \& Gimbert, 2001). Few studies exist regarding teacher preparation for character development, and those available indicate that training received or provided for this task is minimum, if at all (Milson \& Mehlig, 2002). The literature for teacher education in character development addresses two areas: pre-service (prospective teachers) and in-service teachers (experienced, practicing teachers). Pre-service teachers are student teachers enrolled in education programs at colleges or universities where they learn the skills and techniques of teaching. In spite of the learning environment, 
prospective teachers are not taught strategies to teach character education. The literature regarding pre-service teacher preparation to teach character reveals that researchers are concerned with the lack of attention that colleges and universities have given to character education training for pre-service teachers, the lack of character development of preservice teachers and the content of the curriculum for character education (Howard, 2005; O’Sullivan, 2005; Prestwich, 2004; Weber, 1998). Colleges and universities are not convinced that they can afford to add one more item to their pre-service teachers' curriculum. Perhaps they should consider expanding the course for discipline or class room management to include character development.

Literature from the early 1990s through 2005 reveals that colleges and universities are not focused on training teachers to teach character. Although some higher education institutions offer courses in ethics and moral analysis, (Weber, 1998) attention to character development for pre-service teachers does not exist in most education program curricula (Prestwich, 2004). A survey of 212 deans of teacher education programs in 1998 by Jones, Ryan and Bohlin found that $90 \%$ of the deans believed that moral education belongs in the classrooms and schools; $81 \%$ said it was difficult to fit moral education into the curriculum; $24 \%$ reported that it was emphasized in their curriculum; $13 \%$ were not satisfied with the position moral education holds in their teacher education program. The results of this survey indicate that educators see the importance of character education in the classroom, but are not willing or in the position to implement it into their programs. If institutions that prepare teachers for the classroom are not preparing them to develop students' character, then character education will lack 
the trained professionals to implement it. Without a well prepared educator to teach character a character education goal will not be reached.

Researchers argue that moral education plays a small role in teacher education programs. However, if implementation of character development is to be successful, character education must become center stage and be awarded a greater role in teacher education programs (Berkowitz, 1998; Howard, 2005; O’Sullivan, 2005). A study conducted by Mathison (1998) of 137 student teachers from San Diego State University revealed that pre-service teachers were not sure of the legality of discussing contemporary moral issues with students. Although the student teachers in this study agreed that teaching character was important, they did not think they were equipped to teach it. With more school districts adding character education as another focus to curriculum, colleges and universities will have to address the demand for teachers who are equipped to teach character education and recognize the importance of including character education into their teacher education curricula (O’Sullivan, 2005). Not training teachers to develop students' character is one way of assuring an ineffective character education program. Professional development provides teachers with implementation strategies.

Developing the character of the pre-service teacher is discussed in the literature as well. Nicgroski (1992) notes that during the 20th century colleges focused on developing the students morally as well as preparing them to contribute to the workforce. Yet today, higher learning institutions are concerned with preparing students to succeed economically while ignoring the moral or ethical aspect gaining success. One of the strategies for teaching character is modeling which requires the teachers to actually 
model the character traits they expect from students. If pre-service teachers are expected to model, then college is the place to learn the traits required to model.

However, colleges face obstacles for providing character education for pre-service teachers. Berkowtiz (1998) identifies six obstacles colleges face: (a) disagreement on the definition of character, (b) the elements of character education, (c) perceived limited space in the pre-service curricula, (d) limited scientific data, (e) lack of expertise and resources, and (f) opposition from public institutions for teaching character education. In addition to the above obstacles noted in 1998, the passing of the No Child Left Behind (NCLB) law in 2000 also adds pressure to teacher education programs to prepare teachers for academic standard-based performance, thus making it difficult for colleges to allocate curriculum space for character education (Howard, 2005). Scholars have suggested solutions to the obstacles preventing colleges and universities from preparing pre-service teachers to teach character.

Acknowledging the obstacles for providing a quality character education curriculum, researchers offer suggestions for infusing the technician-based classes with ethical and character education courses (Freeman, 1998; O’Sullivan, 2005). Recognizing the void in pre-service training for character education, Weber (1998) offers higher institutions a five-phase process for integrating character education into the existing education curriculum for the pre-service teacher:

1. Define character education and determine the performance objective.

2. Agree on the character education content elements.

3. Merge character education elements with the existing curriculum.

4. Decide upon appropriate assessment techniques. 
5. Devise a transition plan to gradually implement new elements.

(pp. 3-6)

These suggestions should assist secondary administrators in developing effective character education elements of the curriculum for pre-service teachers. Merging elements of character education into the present curriculum makes the process durable. However, the problem remains for the in-service teacher who may have the immediate assignment of teaching character without the proper preparations.

In-service teachers are practicing classroom teachers responsible for delivering the curriculum. The effective delivery of the curriculum weighs heavily upon teacher attitude about the curriculum and effective training received to implement it. Teacher commitment to character education is crucial to its effectiveness and success. To ensure that commitment, principals would have to invest time and money in preparing teachers to implement a character education program by providing workshops, seminars and courses as well as leave time. Yet, the literature from the early 1990s until 2004 reveals that the staff development component of character education is vastly underutilized (Berkowitz \& Bier, 2004). As with pre-service teachers, research studies for in-service teachers professional development in character education is also limited (Berkowitz \& Bier, 2004). Researchers note the need for training and offer suggestions for integrating character education into the curriculum but the professional development component is tremendously under developed. Thus, the present study examined the staff development for character education in a Muslim school.

Professional development for character education is offered by institutions and organizations which specialize in providing character education programs to schools. 
Such organizations include: Josephson Institute, Character Education Partnership, The Center for the 4th and 5th Rs (SUNY Cortland), Kenan Institute for Ethics at Duke University, The Heartwood Institute, and The Giraffe Project. Universities advertise seminars, workshops and institutes on the web for character education professional development; Boston University School of Education houses the Center for the Advancement of Ethics and Character (CAEC) a center for character development. This center targets school districts to provide professional development in character education to school personnel including faculty and school administrators (Center for the Advancement of Ethic and Character, n.d.). The studies to measure the effectiveness of the service these institutes and organizations are offering are not available, further emphasizing the need for research in the area of professional development for character education.

The commercial producers of character education programs such as Character Counts and The Giraffe Project provide training for teachers using their programs. Nonetheless, training teachers to teach character will continue to experience a void if higher educational institutions and school districts do not make provisions for professional development in character education.

Teachers' role in developing student character is paramount, but their efforts must join forces with other participants in order to be effective. The following section discusses the role of other players in developing students' character.

\section{Role of Participants}

Teachers are expected to implement the character education curriculum in their school. Consequently, the vast portion of literature on character education is directed 
toward teachers. However, developing character is not an isolated process. The school leader and the parents have a crucial role in a child's character development. This section discusses the role of school leaders and parents in character education.

\section{The Role of the School Leader in Character Education}

As administrative leader of the school, the principal creates the climate and sets the tone for the development of any program, especially character education. Creating a climate of moral feeling derives from the values.

The principal [or school leader] is the key player in the school; from the principal the climate of the school is set. The climate of the school is its moral feeling derived from the values that the principal advocates and makes actionable.

(Normore \& Quick, 2004, p. 337)

The literature regarding the role of the school leader in developing and maintaining a character education program in a school shows that researchers are consistent on their list of ingredients that a school leader needs for establishing and maintaining a successful character education program.

First on the list is modeling. Principals are held to a high standard of moral and ethical behavior by the entire community (Holloway, 2006). Just as teachers are models for students, principals are models for all participants including students, teachers, staff, and parents. Researchers stress the importance that school leaders play as role models for the values and traditions they wish to implement in the school (DeRoche, 2000; Harned, 1999; Holloway, 2006; Normore \& Quick, 2004; Wong, 1998). The old adage "Practice what you preach" appears to be the researchers' collective message. To establish an effective character education program, school leaders must practice the values they 
promote, show genuine respect for all participants, and help others to do the same (DeRoche, 2000; Harned, 1999). School leaders should become aware of their own values as well as advocate the values of the community. Principals who exemplify positive moral values in their work with participants including students foster a sense of community in the school (Holloway, 2006; Normore \& Quick, 2004). Not only should school leaders display ethical beliefs and behaviors they should be role models in developing and demonstrating a personal and professional code of ethics (Harned, 1999; Holloway, 2006). They should undergo the same scrutiny as teachers by submitting to performance assessment and evaluation (Holloway, 2006). Based on the attention given to this topic in the literature, displaying ethical behavior is just as important for the leader as it is for the teacher. Confucius states that "man of ethical humanity must also practice what he has learnt" (Wong, 1998). Similar to teachers modeling desired behavior for students, principals should model the desired behavior expected from teachers. The scholarship review also reveals a discussion of transformational and transactional skills (Harned, 1999; Holloway, 2006; Wong, 1998). According to Harned (1999), a leader needs both transformational and transactional skills to develop an effective character education program. Transformational leadership inspires and motivates followers to a higher level and appeals to the intrinsic, moral motives and needs of the followers by tapping into the resources of the individual as well as appealing to the individual's moral consciousness (Harned, 1999; Wong, 1998). Transformational leadership requires that leaders exhibit the behavior they wish to establish within the membership. Transactional leadership skills are required to build consensus and to reward and recognize members for effort and accomplishments (Harned, 1999). Wong 
(1998) refers to the transactional skills as psychological where the leader draws on motivational techniques such as rewards and incentives for moral behavior. Holloway (2006) claims recognizing students, teachers, parents and members of the community for positive behavior or contributions to the welfare of the school or community is a two-way communication practice that develops trust in the leader. However, critics argue that this is the least effective leadership to moral development because it does not allow students or schools to develop to their full potential (Sergiovanni, as cited in Wong, 1998). Receiving recognition and rewards for doing what is right has the potential of becoming the stimulus or the point of focus for positive behavior. Doing what is right because it is the right thing to do is the highest level of moral development. If the recognition and rewards are removed, then the incentive for positive behavior and perhaps the desire to behave in a positive manner is absent.

A component of transactional leadership is consensus building. Researchers make reference to the importance of consensus building in developing and maintaining a character education program (DeRoche, 2000; Harned, 1999; Holloway, 2006; Normore \& Quick, 2004). Bringing stakeholders together for compromise and agreement on the implementation of the character education program gives the program a healthy start. A school leader implements consensus building at the beginning of a character education initiative by involving the stakeholders in developing the mission statement and setting the goals for the character education program of the school (DeRoche, 2000). Collaborating with stakeholders to form an agreement on the values and tradition that the school will implement for character development is another consensus building strategy (DeRoche, 2000; Harned, 1999; Wong, 1998). Consensus building leads to trust, 
relationships and a sense of community. These are necessary elements in developing character. When school leaders give stakeholders a voice, it develops a sense of community. As Holloway (2006) posits, when leaders listen to teachers and others in the community, and eschew arbitrary actions, he or she builds trust, an essential element in the leadership of character development. Wong (1998) contends that leaders must establish a trusting relationship between students and schools. This happens when leaders themselves are trusted and are effective at involving participants by listening and collaborating with them. A leader's role is paramount to establishing a character education program. Based on the research, consensus building through collaboration and relationship building is one of the key elements for accomplishing the task.

A school leader also assumes the role and responsibility of overseeing the assessments, evaluation and monitoring of the character education program. Before initiating a character education program a leader should make an assessment of the community. This action gives the community a voice and involves it from the beginning as well as offers an opportunity to collect data that is vital to determining the values and traditions the school will implement (Harned, 1999). The leader becomes a standard bearer by helping participants develop standards by which the character education program is guided, measured, judged for effectiveness, evaluated and maintained. This may include program standards, curriculum standards, and partnership standards (DeRoche, 2004). A leader puts in place devices for monitoring the character education program to review and evaluate current practices and structures to determine if they are reaching the intended goal (Normore \& Quick, 2004). By creating a committee(s) to 
evaluate program, not only does the leader assure the life of the character education program to continue, but the quality of the program will improve as well.

In a Muslim school, there is little information about the role of a leader in developing character education. However, literature offers standards by which to measure or compare the role of a leader in a Muslim school. The responsibility of establishing and maintaining a character education program falls in the hands of the leader; thus, while observing the role of the leader in a Muslim school, the standards and criteria given for schools in general will be applied to leaders in Muslim schools. The result of this application is not predetermined; thus, it is open for discovery. In seeking to learn how a Muslim school approaches character education, the question of how the leader establishes and maintains the character education program requires an answer; what responsibilities are undertaken? What style of leadership is implemented? Is the leader's role similar to or different from that of the general school's leadership?

\section{The Role of Parents in Character Education}

During the time of the early Puritans, it was the responsibility of parents to teach moral values (McClellan, 1999). When morality was perceived to be on the decline, the community no longer trusted parents to provide the expected moral education; thus, schooling moved from the home to institutions, known as the common schools. Consequently, moral development became the function of the common school where all white students regardless of financial status would receive the same moral training (McClellan, 1999). Nonetheless, moral education was not completely given over to schools, parents continued to share in the responsibility by providing Sunday school, which took place in the church on Sundays or weekends (McClellan, 1999 p. 42). 
Researchers agree that parents are influential in children's moral development (Berkowitz \& Grych, 1998; Smetana, 1999). Currently, research on the role of parents in character education focuses on explaining the nature of parental influence or the specific nature of the relationship between parenting and moral development. Research studies have shown that parents working in partnership with schools benefit students academically and morally (Berkowitz \& Grych, 1998). Thus, researchers are seeking to learn the specifics of parental influence of a child's moral development. In search of this question they also examine how parents' discipline methods as well as affective and cognitive interactions influence moral development (Grusec \& Goodnow, 1994; Smetana, 1999). Berkowitz and Grych (1998) also examine the specific nature of the relationship between parenting and moral development. They identify eight psychological characteristics and discuss five core parenting processes that are related to moral development. Smetana (1999) uses the social domain theory as the framework to analyze parents' affective and cognitive interactions with their children and how these interactions influence moral development.

According to the social domain theory, children's social knowledge systems are developed from various social interactions characterized by heterogeneity and the coexistence of different social orientations, motivations and goals (Smetana, 1999). Grusec and Goodnow (1994) focus on internalizing moral values and argue that the effects of parents' discipline not the method have an impact on a child's moral internalization. They define internalization as the congruence that exists between parents and children's values (Grusec \& Goodnow, 1994). Researchers (Hoffman, 1994; Kochanska, 1994; Perry, 1994) criticize Grusec and Goodnow's research for lack of clarity and flaws in the integrity of the model. Other researchers (Baumrind, 2008) studied parenting styles to 
determine the role they played in moral development. Baumrind (2008) identifies four parenting styles: authoritarian, unengaged, permissive, and authoritative. According to Baumrind (2008) the styles employed by parents have an impact on children's behavior, influencing their perception of the world and their interaction with other people.

The descriptions of parenting patterns tie in with the description of affective and cognitive interaction presented by Smetana (1999) as well as with Berkowitz and Grych's (1998) five core parenting processes: induction, nurturance, demandingness, modeling and democratic family process. For example, Berkowitz and Grych (1998) describe demandingness as parents setting boundaries and expectations for their children. Baumrind (2008) also assigns setting boundaries and expectations as a characteristic of the authoritative parent. In fact, other similarities that constitute a positive influence on children's moral development are also found in researchers' description of parenting styles and patterns. Berkowitz and Grych (1998) assert that social orientation, self control compliance and self-esteem are influenced by the relationship that parents develop with their children.

Similarly, Smetana (1999) posits that parental social interaction with children facilitates children's moral development. These researchers differ only in descriptive language. Smetana's (1999) discussion of domain specific feedback (explanation and rationale which help children understand right and wrong) corresponds to Berkowitz and Grych's(1998) induction and nurturance, which is also an explanation of moral conflicts or disciplinary actions. Likewise, Grusec and Goodnow (1994) assert that a child's internalization of moral values is facilitated by the relationship between parent and child, 
which determines the child's acceptance or rejection of parental disciplinary actions and moral values; consequently, influencing internalization.

The research that examines parents' role in moral development of children seeks to determine the relationship of the various components and how they impact this area of a child's development. The researchers observed that studies have been limited to White middle class Christian and Jewish families and that it needs to expand to other cultures and groups. Including Muslim families in these studies is an opportunity to expand the research on the role of parents in a child's moral development by examining parent child relationship from a culture that also adheres to religious values that dictate the behavior for parents and children.

The curriculum is the vehicle for implementing character education in schools. In addition to the components of the curriculum, official, operational, null, and extracurricular, schools have participants who are instrumental in carrying out the vast options of programs. The literature review regarding the curriculum of character education in schools will serve as a guide for examining the Muslim school under this case study.

\section{Muslim Schools in America}

In the Muslim community character education or character development is incumbent upon each individual as part of the development of the human being. Character, from the Muslim perspective, is developed when a person practices the values set forth by Islam (Al-Ghazali, 2004). Muslim schools are designed to provide the environment for this to happen. The history of Muslim schools in America began on two tracks. The first track began in the 1930s in Detroit with indigenous African-American Muslims, followers of Elijah Muhammad the leader of the Nation of Islam (NOI). Clara 
Muhammad, the wife of Elijah Muhammad, decided that the public school was not the best environment to instill Islamic values for her children. She withdrew them from the public school to home school. During the 1930s in Detroit, home schooling was not permitted. For this action, Clara Muhammad was threatened by the Detroit authorities with imprisonment. Eventually, Elijah Muhammad and Clara Muhammad established the University of Islam, the NOI educational system (Keyworth \& Ahmed, 2009;

Muhammad, 2007). In 1974 Elijah Muhammad died, and under the leadership of Warith Deen Mohammad, the son and successor of Elijah Muhammad, the NOI became a mainstream Islamic organization with a focus to become a member of the universal world of Islam. Among the many changes that he made, Warith D. Muhammad re-named all the University of Islam Schools "Clara Muhammad" in honor of his mother (Keyworth \&Ahmed, 2009).

For many years the Clara Muhammad schools were the only schools in America serving Muslim students. Those students were children of converts to Islam who were mostly African-American (Muhammad, 2007). In the 1970s, the second track of Muslim schools opened with a different face, the face of the immigrant Muslim. For the same reasons that Clara Muhammad schools were established, the immigrant Muslims since the early 1970s have also established Muslim schools throughout the United States primarily to maintain and instill Islamic values (Badawi, 2006). Presently, there are approximately 222 Muslim schools in North America (Keyworth \& Ahmad, 2009). Even so, the voice of Muslim schools and how they approach character development has been largely ignored by research for character education. In light of the current climate after the 9/11 tragedy, I am aware of how the general media and public may see Muslim 
schools and raise questions about what they are learning. However moving beyond the stereotypes, this study does not address these issues. Instead, this study examined how character education was implemented in a Muslim school's curricula.

\section{Summary}

Clearly, character education has a purpose in educating American students. The path to fostering good character in American youth is crowded with theories, approaches, programs and implementation methods. Educators have to sort through this vast amount of information to select the best approach for the environment they serve. This case study examined how character education was implemented in a Muslim school's curricula. 


\section{CHAPTER III}

\section{RESEARCH DESIGN AND METHOD}

This chapter explains the research method and methodology of this study including the role of the researcher, and descriptions of participants and data collection and analysis.

\section{Purpose of the Study}

The purpose of this study was to examine the ways in which character education was implemented in a religious Muslim school's Pre-k to12 curricula in a South Florida community. The study also examined how the adult participants (teachers, administrators and parents) experience character education, that is, the process through which it is implemented in the school's daily activities.

\section{Research Questions}

Is character education implemented at this Muslim school according to the character education framework as identified by Character Education Partnership (CEP)?

1. How is character education defined in this Muslim school?

2. What is the method of delivery for the character education curriculum in this Muslim school?

\section{The Role of the Researcher}

I am aware of the existing biases that may influence a study when a researcher is a member of the group who is the subject of the study. Because of the composition of the group, I was both insider and outsider. Because the group and I share the practice of the Islamic faith, I was an insider. In other ways I was an outsider. For example, to become Muslim I converted; my parents were not Muslim, therefore I was not born into Islam as 
were many of the participants in this study. In my case, I am an African-American who converted to Islam, which makes me the only Muslim in my predominantly southern Baptist family and continuing my insider/outsider status. Also, considering that the present climate in the United States toward Muslims is similar to the attitude expressed toward African-Americans in the 1960s and 1970s, my experiences as an AfricanAmerican woman in this country afford me a certain awareness of conditions and circumstances that those born into other cultures may not be aware of. Thus, experiencing prejudice and stereotyping in this society during that time, I understand the importance of education and character development.

The school community, in which this study was conducted, was of a diverse nature in that most of the faculty were born and educated in another country, yet most of the students were born in America. The following section describes my autobiography and assumptions.

\section{Autobiography}

Establishing and maintaining a relationship with God is important to me. This perspective influences every aspect of my life. In fact, religion is a way of life for me; therefore, it is natural that the topic I chose to study, character education, connects to my way of life. I grew up in a southern Baptist family that was very involved in the church. My mother and stepfather were teachers of the Sunday school classes at Josey Creek Bapist church in a small town in Mississippi, and my father was a pastor of a large Baptist church in Tennessee. As a young child I enjoyed participating in church activities. However, as a young adult experiencing discrimination and prejudice during the late 1960s and early '1970s, I began to question religion as I knew and experienced it. I 
wondered how humans could worship the same God and the same religion, yet one group, portrayed in the image of God justified the injustices they placed on another group. That was a major conflict. For a few years I wanted nothing to do with religion, but that did not last because my spiritual self longed for a connection. I began to search for a way of thinking that would answer my questions about religion and human equality. I found the answer to my questions in Islam. I was attracted to Islam because there were no images portraying God as a man. I also understood my purpose on this earth. The following verse in the Qur'an verified that for me:

You are indeed the best community that has ever been brought forth for the [good of] mankind: you enjoin the doing of what is right and forbid the doing of what is wrong, and believe in God (3:110).

The desire to obtain knowledge and to assist others was cultivated by my Islamic faith.

Like religion, education was always emphasized in our family and everyone was expected to attend and graduate from college and so I did. I completed my undergraduate degree and five children and 18 years later, I earned a master's degree. Although it was not my intent, my career has always included working with children; I managed a day care center, worked for Girl Scouts of American, and presently, I am a high school teacher. I started my teaching career in the public school system 24 years ago as a middle school teacher; 4 years later, I moved into high school. Until my 20th year of teaching, I had not taught in a Muslim school environment. In the 2006 school year, while on leave from the public school system, I was offered a job to teach 11th and 12th grade English by the school in which I proposed to conduct my study. I was reluctant to accept the job because of the concern of working in the same environment in which I planned to 
conduct a research study. After wrestling with the idea, I realized that this was a chance to experience the atmosphere of a Muslim school from the inside, because my previous experiences had been as an outsider. I knew that being an employee as well as a researcher in the same school, would require me to closely manage and monitor my subjectivity. I also saw this as an opportunity to better understand the professional development needs of Muslim teachers. While working in the school environment my daily experience allowed me to observe students in an environment designed to cultivate an Islamic personality. I observed the methods used to attempt to accomplish this goal. Having worked in the public school, I noted the contrast and similarities in the environments immediately. This was an experience that provided insight into the uniqueness of this Muslim school environment. At the end of the school year in 2009, my leave time ended and I returned to the public school environment.

As a teacher, I have used my knowledge to assist teachers in Muslim schools. I have felt it necessary to give them opportunities for networking and professional development. I initiated the idea of establishing an organization that would serve in that capacity; consequently, with the help of five other Muslim educators, Muslim Teachers Association (MTA) was established. Through this organization, I visited Muslim schools and worked with Muslim teachers and established relationships with Muslim teachers across the two counties in the region. Working with Muslim teachers, I became aware of their concerns and obstacles. Therefore, I entered the doctoral program knowing that I wanted to study a topic related to teachers in a Muslim school, "Who I am determines to a large extent, what I want to study" (Mehra, 2001, p. 72). I am a Muslim and a teacher, 
so I knew that I wanted to study a topic related to Muslim teachers, yet the specifics were unknown.

The specifics of my study were revealed after reading an article written by Lickona (1991) on character education. I experienced an epiphany. His concept of character resonated with my idea of a Muslim personality. Someone who did what was right regardless of who is watching. I knew then my topic would be character education. I saw character education as a possible avenue for Muslim educators to enhance the students' understanding of Islam. From my experience as a student of Islam, I knew how important it was to understand the purpose of prayer, the benefit of fasting and the reason for modesty. I always want to know why. To make this a good marriage - character education and Muslim schools' curricula-I needed to know more about character education and character development as it related to a Muslim school's curricula. First, it was necessary to gain more knowledge about character education and second, to learn how character was implemented in a Muslims school's curricula. Therefore, examining a Muslim school's curricula to understand how character education was implemented was the focus of this study.

\section{Assumptions}

This study was based on the following assumptions:

1. Character education is implemented in this Muslim school.

2. Muslim schools have the resources to develop students' character. 


\section{Biases}

To manage and monitor the subjectivity that accompanied this qualitative case study with the researcher as a participant, I implemented the following safe guards suggested in the book Qualitative Data Analysis by Miles and Huberman (1994):

\section{Avoid biases created by researcher effects on the site.}

Become familiar with the site; spend as much time as possible on the site. I spent 3 years on the site as a teacher. Prior to becoming a teacher at the site, this researcher organized education conferences for Muslim teachers in the community of Muslim schools in the South Florida area. I also conducted two workshops with teachers at Taqwa Academy on pedagogical strategies. Thus, the teachers were familiar with me on a professional level.

Make sure your intentions are unequivocal for informants. Teachers, administrators and parents interviewed were given a letter explaining the purpose of the study, how and when data would be collected. The president of the school informed the teachers and other administrators that I would be conducting a study at the school.

Do some interviews off campus. Three interviews were conducted off campus: an administrator, a staff member and a board member. Three e-mail interviews were conducted with a former teacher and two parents.

Avoid biases effect on the researcher.

Spread out the informants. Participants interviewed included one former staff member, one non-teacher staff member, two parents, one administrator, a board member, three division leaders, which included the Islamic studies division head who was also a 
teacher. Of the eight teachers interviewed, three were Islamic studies teachers and five were academic teachers.

Spend time away from the site. This researcher worked part time at the school, 4 hours per day and 3 days a week. After the third year of employment this researcher returned to the public school system.

Include dissidents. Interviews were conducted with teachers and parents who did not agree with the amount of attention the administrators of the school gave to developing students' character. These parents wanted more than academics. They felt character building was equally as important as academics and they felt more emphasis was placed on academic efforts than on the efforts of teaching students' character.

Consider informants that will provide historical and background information.

The long time board member, a non-teacher staff member, and two administrators provided background and historical information about the school.

Collect data off-site. Off-site data were collected at school graduations and during school field trips. Three interviews were conducted offsite. The participants met with me away from the school.

Triangulate with several data collection methods. This researcher triangulated by collecting data through three methods: Document analysis, interviews and observation-classroom, extra-curricular, and school routines.

Member check. Interviewees were provided a copy of the transcript of their interview and asked to verify the transcript for accuracy of the information. No one responded to this request. After the report was written, I sent copies of the findings to the 
head of the high school division and the head of Islamic studies of Taqwa Academy. The members responded through e-mail and telephone. The findings were supported.

\section{Design}

A qualitative single-case study methodology was used to examine how character education is delivered at Taqwa Academy, an accredited Muslim school of 300 students in the Southeastern region of the United States. Document analysis, observations and interviews was used to understand how participants at Taqwa Academy made meaning of their lives or experienced character education. The goal of qualitative research is to understand a subject from the perspective of the participants (Bogdan \& Biklen, 2003). Because this study sought to understand how character education was experienced in a specific Muslim school and how the participants made meaning of character education, qualitative research methodology was the best approach to accomplish this goal. According to Yin (1989), qualitative research allows the researcher to facilitate the understanding of a phenomenon by conducting a "close-up detailed observation of the natural world by the investigator" (p. 25). To address the research questions of this study, exploratory and descriptive research that stressed the importance of context, setting and subject's frame of reference was the best approach (Marshall \& Rossman, 1989). Through a deep description of the school's curricula including official, operational, extracurricular and hidden, the researcher sought to show how this Muslim school implemented character education.

A single-site case study was chosen to develop an in-depth description of the experience of character education in this Muslim school. The nature of the case study allows parameters for the research question to be transferred to other Muslim schools 
providing comparative and contrasting data (Miles \& Huberman, 1984). This study sought to understand the phenomenon of character education as it was experienced in the real-life context of a Muslim school. Following Yin's definition of a case study, the present study investigated the phenomenon of character education within the real-life context of a Muslim school. Multiple sources of evidence were used such as document analysis, interviews of teachers, a board member, parents, staff and administrators. Formal and informal observations of classrooms, school activities and events were also used as evidence to determine how character is implemented at Tawqa Academy.

\section{Setting}

Taqwa Academy, established in 1987, is a pre-k-12 comprehensive Muslim school that has graduated 13 classes to universities and colleges in the state of Florida. Located in a suburban city in the southeastern region of Florida, at the time of the study, this school had a population of 300 plus students including pre-school, elementary, middle and high school. The school is accredited by two accrediting agencies, Southern Association of Colleges and Schools (SACS) and the Florida Council of Independent Schools (FCIS).

The campus had two academic facilities providing classrooms for Pre-k to 12th grade, a library and school office. A third facility on the campus was the masjid, the focal point of many important school and community activities. The gold colored dome on top of the structure signaled the location of the masjid, which provided classroom space as well as a location for school assemblies. In addition to school activities the masjid was a place for religious activities daily; at 1:30 p.m. the students and faculty gathered in the masjid for dhur prayer. Once a week on Friday, at 1:30 p.m. the community converged 
upon the campus to join students and faculty in the masjid to fulfill the Muslims' obligation to attend Jum 'ah, the congregational prayer.

During the study, at any time during snack or lunch young students could be seen climbing on the wooden structure or swinging from the bars on the playground bordered by a white picket fence or hitting the volleyball across the net in the open space behind the library. During snack and lunch, older students were observed playing soccer or cricket, a game favored by the Caribbean segment of the diverse population of students. The population of the school was comprised of students who were of Caribbean, Pakistani, Arab, Bangladesh, Ethiopian, Samali, and African American parentage. The faculty and staff were diverse as well, including Arab, Caribbean, African American, Pakistani, and Caucasian individuals.

This school was chosen because the researcher wanted to include high school in the study and this school has a high school division, whereas, other Muslim schools in the area extend only to middle school.

\section{Participants}

The qualitative case study design of this study required a reliance on people who experienced the phenomenon of character education in the school. Participants in this study were purposefully chosen because they had the experience of working in the school and providing students with the experience of character education elements of the curricula; therefore, interviewing and observing them in the classroom facilitated answering the research questions. The participants in this study included administrators, teachers, and parents. 


\section{Administrators}

Formal interviews were held with four administrators: one dean of curriculum, and three department division leaders. The three division leaders were also teachers; therefore, division leaders were counted with the faculty and staff. The dean of curriculum had been with the school for 11 years beginning as a science teacher and later becoming the dean of curriculum. In the middle and high school there were three divisions: middle school, high school, and Islamic studies. Three division leaders represented those areas. The division leaders' tenure with the school ranged from 8 to 4 years. They were chosen for an interview because of their role as school leaders.

\section{Teachers and Staff}

Formal interviews were conducted with each of the teachers from the middle and high school. Excluding division leaders who were also teachers, there were seven teachers in the middle and high school, and six of those teachers were interviewed. To include the perspective of character education from teachers from the elementary department, the first- and third-grade teachers were also interviewed and the third-grade teacher's class was observed. Two teachers in the high school division were not interviewed due to scheduling conflicts, but were nevertheless observed. Teachers included in the interview were two math teachers, two teachers in the Islamic studies division, one English teacher, one science teacher, and one non-staff member. The nonteacher staff member was interviewed to get insight from a different perspective. Miles and Huberman (1984) suggest interviewing those on the "peripheries of the curriculum to collect contrasting and comparative information that could provide insight about the phenomenon" (p. 42). For this reason, the counselor was interviewed. The counselor 
interacted with students under different circumstances. For example, he or she saw students under non-academic circumstances, usually related to behavioral or social issues. Another peripheral interviewee was a former faculty member who had held a nonclassroom position. This former staff member was interviewed through e-mail. The interview offered data from a participant who was familiar with the school environment and who worked with all divisions, teachers and students. The staff's member departure occurred 6 months prior to the interview.

A total of 11 participants were interviewed in this category. Their years of experience with the school ranged from less than 1year to 10 years. Interviews were conducted for a period of 4 weeks. Each participant gave a 1-hour formal open-ended and focused interview. Table 1 below displays the participants, the grade level, and subject taught if applicable. The chemistry teacher and physical education teacher were not interviewed because of scheduling conflicts, but they were observed. To protect the identity of the participants, their names were changed. In addition, each person interviewed was given an information letter (Appendix A) describing the study, including the purpose and the participants' role in the study. Moreover, the letter provided an explanation of the participants' rights as well as how the interview information would be used.

\section{Parents}

Two parents were selected for an interview based on the following criteria: (a) ability to communicate easily in English, (b) availability, (c) willingness to participate (d), and not being a teacher in the school. One parent's child graduated the year the data were collected after being a student in the school since second grade. At the time of the 
study, the other parent's child was enrolled in the ninth grade and had been in the school since fourth grade.

Table 1

Participant Profiles

\begin{tabular}{|c|c|c|c|}
\hline Pseudonym (initials) & $\begin{array}{l}\text { Grade } \\
\text { Level } \\
\text { Taught }\end{array}$ & Subject Taught & Interview/Observed \\
\hline Faheema Qureshi (F.Q.) & 1st Grade & Academic Subjects & Interviewed \\
\hline Jamila Ahmed (J.A.) & 3rd Grade & $\begin{array}{l}\text { Language Arts/Social } \\
\text { Studies/Writing/ } \\
\text { Reading }\end{array}$ & $\begin{array}{l}\text { Interviewed/ } \\
\text { Observed }\end{array}$ \\
\hline Mustafa Salim (M.S.) & $\begin{array}{l}\text { 6th/8th } \\
\text { Grades }\end{array}$ & Math & $\begin{array}{l}\text { Interviewed/ } \\
\text { Observed }\end{array}$ \\
\hline Mona Richardson (M.R.) & $\begin{array}{l}\text { 6th/9th } \\
\text { Grades }\end{array}$ & English & $\begin{array}{l}\text { Interviewed/ } \\
\text { Observed }\end{array}$ \\
\hline Maryam Islam (M.I.) & $\begin{array}{l}\text { 6-12th } \\
\text { Grades }\end{array}$ & Qur'an & $\begin{array}{l}\text { Interviewed/ } \\
\text { Observed }\end{array}$ \\
\hline $\begin{array}{l}\text { Haleem Abdul Hakim } \\
\text { (H.H.) }\end{array}$ & $\begin{array}{l}6-12 \text { th } \\
\text { Grades }\end{array}$ & $\begin{array}{l}\text { Islamic } \\
\text { Studies/Division } \\
\text { Head-Middle School }\end{array}$ & $\begin{array}{l}\text { Interviewed/ } \\
\text { Observed }\end{array}$ \\
\hline Anthony Beliz (A.B.) & $\begin{array}{l}\text { 6-12th } \\
\text { Grades }\end{array}$ & Physical Education & Observed \\
\hline Mukhtar Mubarak (M.M.) & $\begin{array}{l}\text { 7th/8th } \\
\text { Grades }\end{array}$ & $\begin{array}{l}\text { Social } \\
\text { Studies/English/ } \\
\text { Division Head-High } \\
\text { School }\end{array}$ & $\begin{array}{l}\text { Interviewed/ } \\
\text { Observed }\end{array}$ \\
\hline Qasim Imam (Q.I.) & $\begin{array}{l}\text { 9-12th } \\
\text { Grades }\end{array}$ & Math & $\begin{array}{l}\text { Interviewed/ } \\
\text { Observed }\end{array}$ \\
\hline Carlos Sanchez (C.S.) & $\begin{array}{l}9-12 \text { th } \\
\text { Grades }\end{array}$ & $\begin{array}{l}\text { Social } \\
\text { Studies/Division } \\
\text { Head-Middle School }\end{array}$ & $\begin{array}{l}\text { Interview/ } \\
\text { Observed }\end{array}$ \\
\hline Sadeq Hasan(S.H.) & $\begin{array}{l}\text { 9-12th } \\
\text { Grades }\end{array}$ & $\begin{array}{l}\text { Islamic } \\
\text { Studies/Arabic }\end{array}$ & $\begin{array}{l}\text { Interviewed/ } \\
\text { Observed }\end{array}$ \\
\hline Nasir Kareem (N.K.) & $\begin{array}{l}\text { 9-12th } \\
\text { Grades }\end{array}$ & Chemistry & Observed \\
\hline Ghana Asad (G.A.) & Substitute & Qur'an & Observed \\
\hline Fawzia Khan(F.K.) & $\begin{array}{l}\text { Adminis- } \\
\text { trator }\end{array}$ & Dean of Curriculum & Interviewed \\
\hline
\end{tabular}

(table continues) 
Table 1 (continued)

\begin{tabular}{|c|c|c|c|}
\hline Pseudonym (initials) & $\begin{array}{l}\text { Grade } \\
\text { Level } \\
\text { Taught }\end{array}$ & Subject Taught & Interview/Observed \\
\hline Dr. Allen Ahmed (A.A.) & $\begin{array}{l}\text { Board } \\
\text { Member }\end{array}$ & Chairman & Interviewed \\
\hline Elain Thomas (E.T.) & $\mathrm{N} / \mathrm{A}$ & $\begin{array}{l}\text { Counselor/Grant } \\
\text { Writer }\end{array}$ & Interviewed \\
\hline Madga Walid (M.W.) & $\mathrm{N} / \mathrm{A}$ & $\begin{array}{l}\text { Former faculty } \\
\text { Member }\end{array}$ & Interviewed \\
\hline Parent \# 1 & Parent & Student graduating & Interviewed \\
\hline Parent \# 2 & Parent & Student in 9th Grade & Interviewed \\
\hline
\end{tabular}

Note. Participants' profiles confirmed by member check.

\section{Data Collection}

To increase reliability, three sources for collecting evidence were used in conjunction with each other to corroborate information found in each respectively: document analysis, interviews, and observations of: classroom, events, and daily activities.

\section{Document Analysis}

Document analysis included analysis of official, internal and external documents that were relevant to obtaining the official perspective of the organization (Bogdan \& Biklen, 2003; Yin, 1989). The data collected from official documents revealed the values of the organization; in this case, this researcher was looking for evidence of character education. The following sections include a description of the official, internal and external documents.

Official documents. These documents included the mission statement and goals of the school. The mission statement stated the focus and vision of the school and the goals further defined the school's mission by stating in specific terms what the school 
sought to achieve. Additionally, student and faculty manual and handbooks were examined because they provided the policies and procedures for students, faculty and parents. These documents were examined for evidence of character development. Other official documents reviewed for evidence of character education and its implementation in this school were the Islamic studies and academic curricula. The Islamic studies curricula for grades third, sixth, eighth, ninth and 11 were analyzed.

Internal documents. Documents transmitted within the school's channels of communication were reviewed for indications of character education: memos and minutes for meetings.

External documents. External documents were used to communicate to the outside world. These documents presented the image that the organization wanted the public to see (Bogdan \& Biklen, 2003). The list included letters home to parents, newsletters, school publications such as yearbooks, brochures and pamphlets, and the school's website.

\section{Interviews}

Another source for collecting evidence of character education for this case study was interviewing. The interview questions were open-ended and focused. Following Yin's (1989) definition of open-ended interviews, the respondents were asked to give facts about a specific topic and they were also allowed to give their opinion as well as offer insight regarding the topic. Yin described the focused interview as being conducted in a short period of time, an hour. He said that it may be open-ended with a conversational structure; however, the researcher may ask a specific set of questions from the protocol. In this case study, the participants were asked specific questions about 
character education (see Appendix B) as well as encouraged to give their insight about character education as they experienced it in the school, Taqwa Academy. Interviews were conducted in one 1-hour session. Initially, it was proposed to conducted two 30minute sessions but the first session yielded answers to all the questions on the protocol.

During an interview, if it was necessary, I asked additional questions to probe for more details or clarifications. With participants' permission, interviews were taped recorded. A professional transcriber was used to transcribe recorded interviews. The transcription of each participant's interview was sent to the respective person requesting feedback or corrections. No one responded with corrections or questions to this request. Three interviews were conducted through email correspondence, two parents and a former teacher. After requesting an interview, it was decided that for their convenience I would e-mail them the questions and they would answer the questions and return them via e-mail. Interview data were corroborated with data collected from documents and observation.

\section{Observations}

The classroom observations were selected based on middle and high school divisions' highest and lowest grades: the sixth and the eighth grades were the lowest and highest in the middle school and the ninth grade was the lowest in the high school division. The 11th grade was selected because in this school at the 11th and 12th grade level students shared the same teachers, and except for a few courses, students were mixed according to ability levels in the Islamic studies, math and science courses. The third grade was selected for classroom observation in the elementary division because the third grade was the middle grade before entering middle school. 
Observation of classroom, events and extra-curricular activities were conducted to corroborate the information found in official documents and participant interviews. As an employee of the school, I participated in most of the daily activities; therefore informal observations occurred frequently. For example, when participating in morning assembly, I would make mental notes of any activity that was evidence of character education and later write it down in my journal. For example, on one occasion, the morning assembly was used to admonish misbehavior and the middle school division leader spoke to the students about respect and how respect is an important virtue in Islam. The informal observations were valuable because they allowed observation of the participants in a noninstructional setting.

Formal observations. Formal classroom observations were conducted to gain insight into how teachers implemented the operational curriculum concerning character education. Academic and Islamic studies classes were observed based on grade levels: third grade, sixth grade, eighth and ninth grade. Because of the small class size and nature of the courses, Islamic studies courses at Taqwa Academy were mixed for 10th, 11th and 12th grade students. In the math and science courses 12 th graders were enrolled in Advanced Placement classes for math, science and world history. These classes met after school or on Saturday mornings. The younger group, 11th grade was selected because their traditional classes met during the regular school day. The third grade was selected because it represented the middle of the elementary grades in that the third grade falls between the lower elementary grades first and second and the higher elementary grades fourth and fifth. 
A total of 10 classroom observations were conducted from March 23 to April 28, 2009. Each observation was conducted in half day intervals morning or afternoon: for the first observation the researcher observed the grade level's morning class sessions and for the second observation the researcher observed the grade level's afternoon class sessions. Class periods were 45 minutes in length. The morning observations were from 8:15 a.m. to 12:15 p.m., and the afternoon observations were from 1:30p.m. to 3:15 p.m. These formal observations included academic and Islamic studies classes.

Arrangements were made with teachers in advance to get permission to observe their classes. I arrived with the students and sat in the back of the room. Because I was a teacher in the school, I was not a stranger to most of the students.

During these observations, I looked for evidence of character education in the room environment and in the teacher's interaction with students as well as the teacher's use of pedagogical techniques that promoted character education. The room environment included what teachers placed on the walls around the room that pertained to character education. A teacher' interactions with students included the way the teacher spoke to the students and the enforcement of rules that pertained to character education as stated in the handbook and manual of the school. Pedagogical techniques observed included but were not limited to modeling, storytelling, literature, intentionally teaching a character trait, and class discussions related to character education. During these formal observations, I took notes on what I observed happening in the classroom, the activity of the class and student- teacher interaction. I also described what I observed that was on the boards or walls such as posters or images as well as the seating arrangements in the class. My field notes included dialogue between teacher and students as well as actions of both teachers 
and students. Recording (handwritten) dialogue provided data concerning teacherstudent interactions and recording actions provided data concerning interactions and pedagogical techniques that promoted character education. Emerging patterns of character education was sought from these observations.

Informal observations. The informal situations included extracurricular activities and special events such as Cultural Day, graduation, club meetings and field trips. The informal observations also included observations of daily activities such as daily assembly for elementary and middle/high school, daily prayer (dhur), Juma'h prayer (Friday congregational prayer with community), snack and lunch. Meetings were also observed including student government meetings, and faculty and department meetings. Field notes for extracurricular activities, field trips and special events were taken after the event was over. For daily events including morning assembly, prayer, snack and lunch, field notes were made over a period of several months, mentally and written. Field notes were taken after meetings using minutes and agenda items. I also recorded my thoughts and feelings about the meetings.

\section{Data Analysis}

This case study data analysis sought to answer how character education is implemented in a selected Muslim school's curricula. "Data analysis is the process of bringing order, structure and meaning to the mass of collected data" (Marshall \& Rossman, 1989, p. 112). Analyzing qualitative data is a search for general statements about relationships among categories of data organization, theme development, testing and report writing (Marshall \& Rossman, 1989). Data analysis in this study continued throughout the process of data collection, interpreting simultaneously while collecting 
data from the field and sorting data into categories (Creswell, 1994). Organizing data to reduce the volumes of collected evidence and making it manageable is a challenging task that must be balanced between efficiency and design flexibility. If structure is too mechanical, the researcher may miss subtle themes and connections (Marshall \& Rossman, 1989). To explain the data analysis for this study, the following section was divided according to the primary research question and secondary research questions. The section starts with the secondary research questions: How is character education defined in this Muslim school? What is the role of the character education curriculum at this Muslim school? The section ends with the major research question: How is character education implemented in this Muslim school's curricula.

\section{Definition of Character Education in this Muslim School}

To explore the research question of how character education is defined in a selected Muslim school, this section describes the deductive analysis used to examine the data source for this question. The participants' transcripts were the data sources used for this analysis.

Theoretical framework. The definition of character education as defined by the CEP (2008) is expressed as an, "intentional proactive effort by schools, and states to instill in their students important core ethical and performance values such as caring, honesty, fairness, diligence, responsibility, fortitude, and respect for self and others"( $p$. 1). The values or desired behaviors were also referred to as traits or virtues. This definition was used to determine how character education was defined at Taqwa Academy. The traits selected for the definition were limited to the ethical and performance values identified by CEP as caring, honesty, responsibility and respect for 
self and others. This selection was made because these are commonly valued traits in the broader society. The following section describes the analysis of the participants' definitions of character education as compared to the definition by CEP.

Analysis of process used to define character education. My first step in determining how the participants at this Muslim school defined character education was to compare their definition to CEP's definition to determine whether the participants defined character education as an intrinsic or extrinsic process. To make it easier to compare the participants' definitions to CEP's definition, I separated the CEP's definition into two parts. The first part represented the action applied to produce the desired behavior (which I called the process). And the second part represented the results after applying the action or the process, which I called the expected behavior.

The following steps were taken:

1. In CEP's definition, process is represented by the infinitive phrase "to instill." The term "instill" means infusion little by little; so the students will be infused with character building little by little. Infusion connote inward. Instead of using the term "instill" to identify the categories, I used the term intrinsic and extrinsic as the categories because intrinsic means inward and relates to instill in that sense; moreover, I could used the opposite of intrinsic, extrinsic, to identify a process in the definition that did not include inward action.

2. The second part, expected behavior, is represented by core ethical values such as caring, honesty, responsibility and respect for self and others. In this step I examined the transcript of each participant's definition of character education for those traits. Each term representing a trait was coded with the letter T. On a 
spread sheet, I listed the participants and the traits they identified in the definition.

3. In the next step I separated each participant's definition into two parts and identified the language that each used to express the first and second part of the definition. I applied the following questions: Is this process intrinsic, similar to the process used in CEP's definition or is it extrinsic? Then, I analyzed the expected behavior. Does this expected behavior include the value traits similar to the value traits in CEP's definition? The expected behavior was also analyzed to determined the language used to describe the trait, secular or religious language.

4. The above procedure was repeated for each participant to determine the pattern for defining character education by the participants at Taqwa Academy.

Data for the participants' definitions of character education were collected from answers to three interview questions from each participant's transcript. The first question asked the participant to define character education. When necessary, for clarification purposes, probing or follow-up questions were asked. The second question asked the participant to give an opinion of good character. The third question asked the participant to identify core values taught at the school. From the responses to these questions, the participant's definition of character education was recorded and analyzed using the procedure described above. The following section describes the procedure for analyzing the method of delivery of the character education curriculum at Taqwa Academy.

\section{Method of Delivery for the Character Education Curriculum in This Muslim School}

The literature revealed that there were two methods for implementing a character education program or curriculum, integrated or add-on (Lickona, 2007; Milson, 2000). Integration requires that character education is experienced throughout the curriculum. In 
a school setting, an integrated character education curriculum is in every aspect of the school. However, with the add-on model character education is separated from the regular curriculum of the school. It is presented at a specific time of day or on a specific day. For example, the school may choose to have a specific course designated to teach character or designate a homeroom time to teach character.

The data source for this question was the participants' responses to two interview questions. One of the question posed to the participants was what percentage of the responsibility of character education was given to academic and what percent was given to Islamic studies classes. After describing to the participant the difference between addon and integration, they were asked to identify which delivery method used at Taqwa Academy, add-on or integrated. The responses were underlined and highlighted. The next section described the analysis used to respond to the research question concerning how character education is implemented in a selected Muslim school's curricula.

\section{Principles of Character Education in This Muslim School Curricula}

The overall principles of character education developed by Lickona et al. (2007) for the CEP was used to determine if Taqwa Academy's character education initiatives had the criteria that the literature identified as effective principles of character education. The principles developed by CEP encompass pedagogical strategies, school climate, professional development, community involvement, assessment and evaluation. This analysis was not to determine the effectiveness of character education at Taqwa Academy. However, it was to identify those principles in Taqwa Academy's curricula using the data sources to provide evidence. The procedure used for this analysis included the following: 
1. Two literature sources were examined to determine a list of criteria for character education-CEP's Eleven Principles of Effective character Education by Lickona et al. (2007) and Berkowitz and Bier's (2004) "What Works in Character Education." The two lists were examined for similar criteria. Only one item on Berkowitz and Bier's list varied from the CEP's list. However that item was omitted, because its evaluative focus was not consistent with the purpose of this study. The decision to use the CEP's list was based on the fact that CEP had additional resources to assist in understanding the principles, which made it easier to determine if evidence of the principles did or did not exist in Taqwa Academy's data sources, which included participant interviews, document analysis and observations, formal and informal.

2. Each of the 11 principles was addressed individually. The data source(s) that applied to the principle was (were) examined and coded with the corresponding number of the principle. As mentioned before, the data sources are participant interviews, document analysis and observations, formal and informal.

3. After finding and coding the data source(s) that applied to the principle, the information was recorded on a spreadsheet to use for the written report. This procedure was repeated for each principle.

\section{Summary}

This chapter presented the case-study design method used for this study of Taqwa Academy, a private Muslim school. The purpose of the study was to learn how character education is implemented in the school's curricula. Data were collected from the following sources: Participant interviews, document analysis, and classroom observation. 
A deductive analysis was used to analyze data. The findings are presented in the next chapter of this study. 


\section{CHAPTER IV \\ DESCRIPTION OF FINDINGS}

This case study examined how character education is implemented in a Muslim school's curricula. In this chapter the findings from the analysis of multiple data sources are presented, specifically, to explore the following research questions:

This chapter is divided into three sections. The first section gives the definition of character education based on Islamic philosophy, published in school documents and defined by the school's participants. The second section addresses how character education is delivered through the official and operational curricula. The official curriculum is defined as that which the school publishes and states as the curriculum and the operating curriculum is that which is actually taught. The third section describes how character education is implemented by comparing character education initiatives at Taqwa Academy to the principles of character education presented in the literature. Findings are reported from document analysis, observations, and interviews.

\section{Defining Character Education at Taqwa Academy}

The definition of character education is based on the focus and the intent of its use (Berkowitz \& Bier, 2005; Lickona, 1999; Wynne, 1997). To determine how character education is defined at Taqwa Academy, three areas were examined: the philosophy of Islam regarding character development, including Islamic values and virtues; the mission statement of the Academy; and the participants' perspectives. Each area is discussed at length in the following sections. 


\section{Character Education Defined in Islamic Philosophy}

Before discussing the definition of character education in a Muslim school, it must be noted that Islam is more than 1,400 years old and, as most religions, is designed to promote character development in individuals. Moreover, the term character education did not appear in the literature of American scholars until the 1990s (Leming, 2001). Thus, a term for character development had been established in the Islamic faith long before formalized character education was introduced. Instead of character education, those who adhere to the tenets of Islam will most often use Islamic personality or Muslim character to refer to the development of one's character.

Philosophically, developing "good character" is an essential aspect of the Islamic faith. Whether referred to as Muslim character (Al-Ghazali, 2004) or Islamic personality (Haneef, 2002), the goal of Islam is to "create an Islamic personality within the individual Muslim” (Haneef, 2002, p. 73). Among the traits that the Islamic personality exhibits are God-consciousness, which means to be aware of the Creator at all times, and to know that He is aware of the individual's actions. An Islamic personality has as its base Islamic values and attitudes on which the personality is built and where Islamic criteria govern all aspects of life (Haneef, 2002). Therefore, the focus of the faith is to help the individual to develop good character by instilling Islamic values and attitudes.

\section{Islamic Personality}

Islamic values and attitudes are supplemented and enhanced by teaching the principles and practices of Islam, through the pillars of Islam. The principles and practices delineated in the pillars of Islam include the shahadah (declaration of faith), salat (prayer), zakat (charity), sawn (fasting), and hajj (pilgrimage to Mecca). Every 
Muslim is expected to learn and practice these five pillars which are "exercises and training to enable people to acquire correct morals and habits..." (Al-Ghazali, 2004, p. 1). Each pillar encases Islamic moral values that are essential in the development of Muslim character and personality. When the shahadah is taken, the individual commits to being obedient to the Creator. In this commitment he or she is said to be exhibiting integrity, honesty, truthfulness and keeping commitments, which are "among the most emphasized qualities in Islam" (Haneef, 2002, p. 90). Haneef also added that these traits require absolute fidelity and honesty in all personal and business interactions and dealings. The second pillar, obligatory prayers, are said to prevent one from committing evil and encourages humility and kindness (Al-Ghazali, 2004). Humility and kindness in an Islamic personality are exhibited by kind treatment to parents, responsible relations with relatives, neighbors, all people, and animals (Haneef, 2002). The purpose of the third pillar, charity (zakat), is said to "sow the seeds of kindness, sympathy and benevolence [as well as] to establish the relationship of love and friendliness" (Haneef, 2002, p.2). Charity connotes generosity in an Islamic personality. Islam requires the individual to respond to the needs of those less fortunate by giving to charity (zakat; Haneef, 2002). Self-restraint and self-discipline are traits said to be developed through the fourth and fifth pillars, fasting (sawn) and pilgrimage to Mecca (hajj; Al-Ghazali, 2004). Fasting during the month of Ramadan and making the pilgrimage to Mecca at least once in a lifetime is said to strengthen will power and assist the individual in controlling various aspects of life such as anger, appetite, and desires (Haneef, 2002). According to Al-Ghazali (2004) and Haneef (2002), adhering to these five pillars constitutes developing a character or personality that is God-conscious, morally correct, 
and beneficial to society. Character education in the context of Islam and Muslim settings is referred to as Islamic personality or Muslim character and is developed by fostering Islamic values and attitudes in students. According to Haneef (2002), these values are taught by teaching the principles and practices of Islam through the five pillars. In the context of Taqwa Academy, a school founded on Islamic philosophy, the principles and practices of Islam are identified in the mission statement and in other official documents such as the manuals and handbooks. This is an indication that the school values those principles and practice.

Although Islamic personality or Muslim character are the terms used in Islamic literature to refer to developing one's character, in this study I will continue to use the term character education because that is the term found in the academic literature. On further examination of the description of Islamic personality/ Muslim character, one find that the focus and intent of fostering an Islamic personality are similar to the focus and intent of character education as used in this study. The traits of the five pillars of Islam are similar to the traits identified by CEP that are considered valuable to developing students' character. For this reason, character education will continue to be used in this study. The next section investigates Taqwa Academy's definition of character education.

\section{Character Education at Taqwa Academy}

How is character education defined in Taqwa Academy, a modern day, full-time Muslim school? To examine the definition of character education at Taqwa Academy, data from official documents such as the mission statement, faculty handbook and manual and the school's website were analyzed. In addition to the official documents, participants' perspectives were also analyzed and compared to the definition found in the 
literature. In the following section the mission statement and other official documents and participants' perspectives of character education provide insight on how the definition of character education is expressed at Taqwa Academy.

\section{Mission Statement}

According to Schubert (1986) the mission statement should state the values of the school. The mission statement at Taqwa Academy states: "To teach students the principles and practices of Islam and to prepare them for academic success and good citizenship." As can be seen, specific values or traits were not explicitly stated in Taqwa Academy's mission statement, and neither is the term character education mentioned in the mission statement. However the phrase, "To teach students principles and practices of Islam" represents the process for morally developing students' character. As established in the previous section "Islamic Personality" teaching the principles and practices of Islam is a way to foster Islamic values and attitudes. Thus, the mission statement at Taqwa Academy stated the values of the school, although, not explicitly. This is an indication that the Taqwa Academy identified the values of the school in the mission statement, consequently establishing a foundation for teaching character.

In addition to the mission statement, in Taqwa Academy's Teacher Handbook

and Manual, under "Policy and Purpose," the statement, "The Academy will make every effort to ensure that each student is well versed in the principles and practices of Islam and that each student upon graduation qualifies for entry into college" (p. 2). This declaration supported the mission statement's claim to develop students' character through the principles and practices of Islam. Also on the school's website under the 
section regarding building Muslim character, a more detailed explanation is provided to describe the school's character education efforts, which included the following:

1. To instill in the students the fundamentals of Islamic principles, disciplines and practices...and comprehensive secular knowledge that would enrich their lives and serve them well through life.

2. Students to leave the Academy well versed in the principles, disciplines, and practices of Islam, able to understand contents and meaning of the Qur'an, with good knowledge of Hadith and command over reading, writing and speak[ing] Arabic fluently.

3. To maintain focus on its [the Academy's] responsibility to guide and assist in building morally strong and healthy personal character of each student on belief that "knowledge without wisdom in application is incomplete and futile."

4. To impart education in a manner that ensures acceptance of the knowledge acquired and executing its compliance as the way of life; for each student making way into the complex and challenging world with the dedication to preserve continuance of knowledge Allah granted.

The expression of character education as described in the school's official documents, appeared to focus on instilling in the student an Islamic way of life resulting in students who were dedicated to continuously producing knowledge granted by Allah. The next section of this chapter reveals the definition of character education as expressed by participants in this study. 


\section{Participants' Definitions}

In an individual interview, participants of this study were asked to give their definition of character education (Appendix C). According to the literature the definition of character education is based on focus and intent (Berkowitz \& Bier, 2005; Lickona, 1999; Wynne, 1997); and the values of those who are implementers of the program (Otten, 2000). The CEP definition of character education is appropriate for a school environment because it addresses character education in schools. The participants' responses to the interview question regarding their definition of character were analyzed by comparing their responses to the definition offered by CEP. A detailed account of the procedures used analyzing the definition is provided in Chapter 3. The participants' defined character education along a continuum of intrinsic or extrinsic, and then the behaviors identified in the traits were categorized as secular or religious.

Intrinsic focus. Intrinsic is defined as belonging to something by its very nature; of or relating to the essential part of a thing; inherent, inward, internal (intrinsic, online dictionary). In defining character education, CEP (2008) used the term "instill," an indication of inward movement. When asked to give their definition of character education, a group of participants in this study used terms such as "formation", "inculcate" and "build." These terms relate to an inward movement similar to "instill." For example, a staff member and former teacher defined character education as "the formation of morals and the formation of responsible relationships with society, school society and community" (E. T. personal communication, April 2009). The term formation related to an inward action on the part of the student. An Islamic studies teacher defined character education as, "the means of developing the character of the students so that they 
can inculcate whatever values they are taught into their everyday life." (H. H., personal communication, April 2009). "Inculcate" indicates internalize; the teacher perceived character education as a means of teaching students to internalize the values taught to them.

Whereas the teachers used "inculcate" and "form," both parents in the study used the term "build." Parent \#1 stated, "an area of education which helps us to build outstanding habits" (personal communication, August, 2009) and Parent \#2 explained, "Character education gives one the tools to build the capacity on how a person interacts with others" (personal communication, June, 2009). In the parents' definition of character education, the phrases "gives one the tools to build" and "to help us to build" suggested the involvement of the student in the development of his or her character. The term "build" suggested that parents were referring to building internal tools with which to operate in both the physical day to day aspects of life and spiritual ways of being and development as human beings. In this definition, although assistance should be available, the actual act of building character should come from within the student. These two teachers and parents used terms that connoted "instilling" or" internalizing," which indicated working from within. The term intrinsic is opposite of extrinsic and it should be noted that several participants used extrinsic terms in their description in defining character education.

Extrinsic focus. Extrinsic means outside a thing outward or external. Some participants' process for character education connoted imparting or working from the outside of the student to develop students' character; they used words such as "make" and "mold." An example of extrinsic language was found in the definition of a math teacher's 
expression of character education. He stated, “...the objective of education is to make a person a better person in the sight of God"' (Q. I., personal communication, May, 2009). "Make" is also used in the definition of character education by an elementary teacher who stated, "We are trying to make a good citizen and good Muslims...a teacher [needs] to train them as a good Muslim and a good citizen (F. Q., personal communication, May 2009). "Make" and "train" are terms that suggest external action; something others do to or for an individual. A middle school teacher also used extrinsic terms to define character education: "Character education involves guidance of students, molding them into what they should be, etiquette, how to get along with other students, how to get along with peers, and teachers, anyone in society" (M. R. personal communication, May, 2009). "Guiding" and" molding" were terms that portrayed the student as the receiver of character education externally. In this case, the student may learn character traits, but may not necessarily commit to them. Moreover, the difference in using intrinsic and extrinsic terms may pose difficulties for character education implementation.

Because some participants used intrinsic terms and others used extrinsic terms to define character education, indicated that there is a difference in how the participants perceive character education. Six participants used extrinsic language to express the definition of character education and eight participants used intrinsic language. There is almost an even split in the process of the definition of character education. This difference in choice of language could also indicate a difference in the participants' perception of the implementation of character education. However, a greater difference is illustrated in the expected behavior segment of the definition. 
Religious and secular reference. After analyzing the expected behavior of the participants' definitions by examining the language used to express the expected behavior, the responses were placed in two categories: religious and secular traits. These categories were appropriate because of the religious context of the school environment, and the secular context of the society in which the school resided. The traits that the participants used to describe the expected behavior for a student involved in the process of developing character was expressed in secular or religious text. The findings showed that when discussing expected behavior for character education, most of the teachers used secular traits. They used traits such as responsible, respect and caring. However two participants, one teacher in the Islamic studies division and the other in the high school math division, expressed the expected behavior for character education in religious traits such as piety and awareness of God.

An example of the religious reference was given by the former participant when asked, "What is good character?" the response was: "I will say it in one word, "piety." I think this is the key for everything....and this goes with something else which is feeling guilty, sometimes blaming yourself. Good character for me is somebody aware of God all the time" (M. I., personal communication, May, 2009). This participant used two traits: piety and awareness of God. As observed in the literature, these explicitly religious traits were not normally applied to behavioral expectations for character education. As indicated above, a math teacher, also used religious traits in expressing the expected behavior of character education:

I think if someone go[es] to an Islamic school, at the end we expect him to first fulfill his personal obligation to Allah like praying, fasting and hajj, refrain from 
evil things like profanity, drugs, alcohol, stealing. Second, he should fulfill his obligation to society. He should see himself as part of the human race; that he is here, as the Qur'an said Allah sent man as the Khalifa, as God's representative to do God's work. Islamic education and character education should be reflected in his philosophy of life. (Q. I., personal communication, May, 2009)

This participant's language appeared to indicate that if an individual has attended an Islamic school, from that experience, the individual should gain a sense of duty to God. Moreover as God's worker, the individual should fulfill his obligation to society and by doing so he also fulfills his obligation to God. It could be argued that "obligation to society," is a secular trait, because society expects individuals to fulfill certain obligations to society. For example, to fulfill their obligation to society, students are required to complete community service hours before graduating from high school. The connotative difference is that the religious community, the Islamic community specifically, associated the behavior of fulfilling the obligation to society with worshiping, whereas, the secular society does not make that association. This is an indication that expected behavior can be expressed in religious or secular terms; it depends on the intent and focus of the user.

Other participants in the study used traits that were also used in the literature. For example, they used traits such as respect, responsibility citizenship and care for others to describe the expected behavior of students having experienced the process of character development. These participants' traits were similar to those used by Lickona et al. in the Character Education Partnership definition of character education (2007). In one example, regarding the expected behavior, a participant provided the following explanation, "A person who is responsible toward themselves and respectful of everyone 
around them" (M. S. personal communication, April, 2009). An Islamic studies teacher stated, “...Being polite, being respectful, to peers and teachers; being a good citizen, being lenient, being soft. And care for others and share whatever you have with others" (S.H., personal communication, April, 2009). The findings from this analysis revealed that most of the teachers expressed the expected behavior of character education in traits identified in the literature as character traits or virtues. Only two teachers used religious traits to describe the expected behavior for character education.

This finding indicated that defining character education at Taqwa Academy is a complex task. There are those whose focus may be secular and this could reflect in their expectation of student behavior. On the other hand there may be participants who are focused on the religious behavior and this too may reflect in their expectation of the students. These expectations do not necessarily have to be conflicting because as established in the beginning of this section, the pillars of Islam ascribe to traits identified by CEP such as responsibility, respect and caring. Nonetheless, the religious terms will carry connotations related to Islam that the secular terms will not have within the school environment.

\section{Summary of the Definition of Character Education at Taqwa Academy}

Character education as defined by Taqwa Academy was analyzed by dividing the definition into two parts, the process and the expected behavior and comparing it to the two parts of the definition offered by CEP. Official documents and participants' responses to three research questions provided data to analyze the school's definition of character education. Analysis of the official documents including the mission statement, teacher's manual and the school's website revealed that the process for teaching character 
was intrinsic, "to instill in the students..." to build from the inside so that the behaviors are normative or natural. The expected behavior expressed in the documents included good citizenship and becoming well versed in the principles and practices of Islam.

However the analysis of the participants' definitions revealed that the process of the definitions for character education at Taqwa Academy was intrinsic for some participants and extrinsic for others. This was an indication that defining character education for participants at Taqwa Academy is complex. The analysis also revealed that the participants expected students to exhibit character traits after experiencing the process of character education. Most participants stated traits that were commonly used by CEP, but other participants identified traits that were associated with religion such as piety and God-consciousness. The findings from the analysis revealed that the definition of character education at Taqwa Academy varies between participants as illustrated in Table 2.

Character education may be defined with different foci and different expected behaviors; therefore it is essential for those implementing a character education program or curriculum to develop a definition that is appropriate for the students that they serve.

Table 2

Participants' Language Used to Define Character Education

\begin{tabular}{lll}
\hline Participants & $\begin{array}{l}\text { Process: Intrinsic } \\
\text { Extrinsic }\end{array}$ & Exp. Behavior: Religious/Secular \\
\hline J.A. & Intrinsic & N/A \\
E.T. & Intrinsic & Secular \\
Parent 1 & Intrinsic & Secular \\
\hline
\end{tabular}

(table continues) 
Table 2 (continued)

\begin{tabular}{lll}
\hline Participants & $\begin{array}{l}\text { Process: Intrinsic } \\
\text { Extrinsic }\end{array}$ & Exp. Behavior: Religious/Secular \\
\hline Parent 2 & Intrinsic & Secular \\
F.K. & Intrinsic & Secular \\
H.H. & Intrinsic & Secular \\
M.M. & Intrinsic & Secular \\
M.S. & Intrinsic & Secular \\
Q.I. & Extrinsic & Religious \\
F.Q. & Extrinsic & N/A \\
S.H. & Extrinsic & Secular \\
M.I. & Extrinsic & Religious \\
M.R. & Extrinsic & Secular \\
M.W. & Extrinsic & Secular \\
\hline Total & 8 Intrinsic & 2 Religious \\
& 6 Extrinsic & 10 Secular \\
\hline
\end{tabular}

This section identified how character education was defined at Taqwa Academy. Another aspect of character education is the delivery method in the curriculum.

The delivery method indicates where the emphasis is placed on the implementation of character education. The next section discusses the method used to deliver the character education curriculum at Taqwa Academy.

\section{Method of Delivery for the Character Education Curriculum at Taqwa Academy}

Identifying the delivery method is significant because it describes how character education is experienced in the curriculum. Where character education is placed in the 
curriculum is indicative of its significance to the school. At Taqwa Academy, character education is referenced in the mission statement in the phrase "to teach the principles and practices of Islam" signifying that it is valued by the school. If this is the case, by further investigating the treatment of character education as a part of the curriculum offered insight in to the schools perception of character education as valued curriculum content. Traditionally, character education programs were treated as add-ons. This treatment is considered by CEP (2007) to be acceptable as a first step, but the most desired treatment for character education is integrated through the curriculum. An add-on character education curriculum is delivered separately from the academic curricula. Consequently, it may be offered at a special time of day, week or month. It may be offered through a specific class or through a specific program. On the other hand, if integrated, character education is implemented through the academic curricula. In this section participants' responses to interview questions and official documents were examined to determine the delivery method used to implement character education at Taqwa Academy.

\section{The Method of Delivery: Participants' Perceptions}

Developing an Islamic personality that reflects the moral values of Islam is equivalent to character education; it is accomplished by teaching the principles and practices of Islam (Al-Ghazali, 2004). According to some participants, the Islamic studies division is given the greater responsibility for teaching character than the academic division, which teaches the core subjects such as science, math English and social studies. When asked what percentage of the responsibility to teach character education is placed on the Islamic studies division and what percentage is placed on the academic division, most participants reported that Islamic studies had the greater responsibility. For 
example, an Islamic studies teacher did not give a percentage but expressed his response with the following description:

I think the Islamic studies department, because [if] anything bad happens is communicated to the Islamic studies department and something has to be done to try and rectify it from that aspect; whether it is cleanliness, whether it is using obscene language, whether it is boy-girl interaction. (H. H. personal communication, 2009)

This participant gave an example of what types of issues that were considered the responsibility of the Islamic studies department. What he described were undesirable behaviors that demonstrated poor character. It also indicated that this participant associated character education with discipline.

Another Islamic studies teacher shared H. H's view. He stated, "I feel kind of an additional responsibility is being given the Islamic studies department in that regard [teaching character], which we try our best" (S. H.). An academic teacher claimed, "I think definitely the religion teachers carry a heavier burden than we do; I would say a good 70\%” (M. R., personal communications, 2009). On the other hand, of the participants asked, the question regarding the percentage of the responsibility of teaching character, one teacher and a parent stated $40 \%$ of the responsibility was placed on the Islamic studies division and 60\% on the academic division (Parent 1 and F.Q., personal communication, 2009). Most of the participants responding to the question regarding the responsibility to teach character education believed that the Islamic studies division was responsible for teaching character at Taqwa Academy. This is an indication that some 
participants of the school perceived character education as mostly taught through the Islamic studies division (see Table 3).

Table 3

Participants' Perspective of the Burden of Responsibility for Character Education

\begin{tabular}{lll}
\hline Participants & Islamic studies & Academic \\
\hline F.Q & $40 \%$ & $60 \%$ \\
M.R. & $70 \%$ & $30 \%$ \\
M.W. & $70 \%$ & $30 \%$ \\
F.K. & $70 \%$ & $30 \%$ \\
J.A. & $90 \%$ & $10 \%$ \\
Parent \#1 & $40 \%$ & $60 \%$ \\
S.H. & $100 \%$ & $0 \%$ \\
H.H. & $90 \%$ & $10 \%$ \\
E.T. & $75 \%$ & $25 \%$ \\
\hline
\end{tabular}

The participants' response may indicate that they perceived character education as developing the students' morals. Since the school has a religious department, it is best that moral development is handled through it. It could also mean that those outside of the religious courses my not feel equipped to teach character because they may not be clear about the meaning of character.

When some participants were specifically asked if character education at Taqwa Academy was added-on or integrated into the curriculum, although some perceived character education as an added-on curriculum, most who responded believed that 
character education was integrated as illustrated in Table 4. For example, of those who perceived the program integrated, one participant explained, "I think it is spread throughout but there is a certain expectation that the Islamic studies teacher has a particular strong role with that and this school system" (E. T., personal communications, 2009). Although E. T. described character education as spread throughout the curriculum, she indicated that there were high expectations for the Islamic studies teacher regarding character education. Another teacher stated, "It is probably integrated. There is nothing separate besides the religious classes, Islamic studies and Qur'an. I think some teachers integrate because it is easier to do in social studies and English as opposed to math" (M. R., personal communications, 2009). The teacher believed that character education was integrated but limited to the social studies and English courses because it is easier for them to integrate. In contrast to integration, there were three participants who stated that character education was an add-on curriculum. "I think it is more added-on. It is not integrated. First of all, you may not have a teacher who is equipped to integrate Islamic studies" (Q. I. personal communication, 2009). This participant, a math teacher, identified Islamic studies as the means for developing students' character and asserted that everyone is not able to teach Islamic studies. This participant suggested that teachers of subjects other than Islamic subjects were not properly trained to teach character.

Table 4

Participants' Perception of Character Education: Added-on or Integrated

\begin{tabular}{ll}
\hline Participants & Perception of Method of Delivery \\
\hline Q.I. & Add-On \\
F.Q. & Add-On
\end{tabular}

(table continues) 
Table 4 (continued)

\begin{tabular}{ll}
\hline Participants & Perception of Method of Delivery \\
\hline J.A. & Add-On \\
M.S. & Integrated \\
M.R. & Integrated \\
M.W. & Integrated \\
E.T. & Integrated \\
S.H. & Integrated \\
H.H. & Integrated \\
Parent 1 & Integrated \\
Parent 2 & Integrated \\
\hline
\end{tabular}

Note: Participants' identified school's character education curriculum as add-on or integrated

This difference in perspective of how character education was delivered at Taqwa Academy was indicative of the complexity of character education even in a religious school. The participants' response suggested that although most of them expected the Islamic studies division to teach character, some of them also believed that teaching character was a shared responsibility.

\section{The Method of Delivery: Official Curriculum}

In the official or explicit curriculum the school presents an image that it aims to convey to the public or "what it admits to teaching" (Schubert, 1986, p. 104). The official curriculum revealed the purpose of the school in aspects of what, when, where and how that purpose was implemented. The mission statement was the document that revealed the mission of the school, which stated, "To teach students the principles and practices of Islam and to prepare them for academic success and good citizenship," but it did not provide an indication of how character education should be implemented. However, as 
stated earlier in this chapter (p.85) on the school's website under the section regarding building character, Taqwa Academy described the focus of character education and identified the religious program as the avenue through which it was implemented.

It appeared that the Islamic studies programs were assigned the responsibility of teaching character. The academic curriculum was not mentioned in this section regarding building-character; however a description of the role of the academic curriculum was located under another page of the website:

The academic curricula endow students' ability to think rationally, critically and to communicate effectively. The Academy pursues to instill through curricular and extra-curricular activities in its students a love of knowledge and scientific inquiry. Within this pursuit, it creates awareness of and respect for the rich historical, literary, and scientific heritage of Muslim and other civilizations. The academic curriculum statement appeared to focus explicitly on the intellectual with an implication for character education, whereas the Islamic studies curriculum statement appeared to focus explicitly on building moral character. This model of separation of the Islamic studies and the academic curricula could be attributed to the fact that most founders and implementers of this Muslim school were educated in a society where there were schools strictly for religious studies and schools designed for academic studies; there was a distinct separation. Their academic curriculum was developed from the Western model. In the United States, the Muslim school provided both Islamic studies and academic courses but as separate curricula. 


\section{Summary}

The above section examined participants' responses and the official documents for evidence of how the character education curriculum was delivered. According to CEP (2007), character education can be implemented through an integrated, "stand alone" or add-on method. At Taqwa Academy there appear to be a discrepancy in what was published in official documents and what was experienced by some of the participants regarding the character education delivery method. Most participants identified character education as integrated at Taqwa Academy, whereas, others perceived it as add-on. When the participants stated that the Islamic studies division was responsible for implementing character education, they implied that the curriculum was an add-on model. This view coincided with the official curriculum, which also assigned the Islamic studies division with the responsibility to teach character. Yet, when asked to choose between add-on and integrated delivery method for character education at this school, most of the participants selected integrated. This view differed from the official statement, where no evidence that the character education curriculum at this school was an explicit integrated model. The Islamic studies division was given the responsibility to teach the principles and practices of Islam through which character education was implemented, indicating an add-on delivery method at Taqwa Academy. In reference to the intellect, the statement on the school website does not explicitly address character education as the content of academic courses but implies character development in the statement, "instill...the love of knowledge and scientific inquiry." This analysis led to the conclusion that the method of delivery for the character education curriculum at Taqwa Academy was not absolutely add-on or integrated. It had features of add-on and partial integration. The next section 
analyzes the features of the character education initiatives at Taqwa Academy by comparing them to the principles of character education as identified by CEP.

\section{Principles of Character Education in Taqwa Academy Curricula}

The CEP's Eleven Principles of Effective Character Education (2007) provided

11 basic principles that were used to determine how character education was

implemented at Taqwa Academy. These principles encompassed pedagogical strategies, school climate, professional development, parent and community involvement as well as assessment and evaluation. This section analyzes Taqwa Academy's curricula for evidence of the principles of character education as identified by CEP (2007). Although the title of the documents use the term "effective" this study was not undertaken to determine the effectiveness of character education at Taqwa Academy. The data sources, participants' interviews, document analysis, and observations were analyzed for evidence that would support or not support the presence of the CEP principles of character education in the curricula at Taqwa Academy.

Lickona at el. (2007) and Berkowitz and Bier (2004) developed characteristics that should be present in effective character education programs. Lickona et al. (2007) published CEP's Eleven Principles of Effective Character Education, which "serves as criteria that schools can use to plan a character education effort and to evaluate available character education programs...” (front cover). Another research team, Berkowitz and Bier --in the article "Research-Based Character Education-"also identified characteristics of successful character education programs. These two documents were compared to determine commonality of characteristics. The components of the two lists were similar except for Quality Implementation which appeared on Berkowitz and Bier's (2004) list. 
This item was not added to the CEP's list because of its evaluative implications. The following is the list of CEP's Eleven Principles of Effective Character Education:

Effective character education:

1. Promotes core ethical values and support performance values

2. Defines "character" comprehensively to include thinking, feeling, and behavior

3. Uses a comprehensive, intentional, and proactive approach to character development

4. Creates a caring school community

5. Provides students with opportunities for moral action

6. Includes a meaningful academic curriculum that respects all learners, develops their character, and helps them to succeed

7. Strives to foster students' self-motivation

8. Engages the school staff as a learning and moral community that shares responsibility for character education and attempts to adhere to the same core values that guide the education students

9. Fosters shared moral leadership and long range support of the character education initiative

10. Engages families and community members as partners in the characterbuilding effort

11. Assesses the character of the school, the school staff's functioning as character educators, and the extent to which students manifest as good character. This list is from CEP (2007). 
Taqwa Academy's curricula were analyzed for evidence of each principle. The following sections compare each of the eleven principles identified by CEP to the character education initiatives of Taqwa Academy.

\section{Promotes Core Ethical Values and the Supportive Performance Values as the Basis of Good Character.}

According to Davidson and Lickona (2007) character education is comprised of two parts: morals and performance values. Morals values include caring, respect, fairness and responsibility and performance values include traits diligence, perseverance and strong work ethics. Character Education Partnership (CEP) identified ethical and performance values as essential for a character education curriculum (Lickona et al., 2007). At Taqwa Academy, ethical and performance values were present in the school curricula. For example, the official curriculum presented the explicit statement of the core values in documents such as the student and teacher handbooks, also in the Islamic studies and academic curricula. An investigation of the operational curriculum revealed how the core values occurred in the classroom. The hidden curriculum demonstrated how core values are not always visible or obvious, yet the influence of the core values was present. Evidence for these core values are presented in the following sections.

Official curriculum. From the official curriculum documents such as the student and faculty handbook and the Islamic studies and academic curricula were examined because they represent the The core values were found in the Student Handbook and Planner; from the beginning of the book, where the front cover of the planner was decorated with words representing ethical and performance values, to the last section of the handbook where 16 virtues or values were defined and explained. The values were 
also found within the handbook in the section describing expected student behavior. For example under the section for "Expected Behavior In the Class" the statement read, "Be respectful in behavior that allows the flow of the class activity whether it is a lecture, discussion or lab. In the section "Behavior Expected outside the Classroom" it was stated, "Behavior outside the classroom will be courteous, respectful, and considerate toward others" (pp.7-8). In an effort to provide an atmosphere for academic development, the importance of honesty is also stressed in the student handbook/planner:

[This Academy] endeavors to provide an atmosphere in which students develop intellectually. To accomplish these objectives, values are taught, learned and practiced daily. Our school encourages academic honesty...It is the responsibility of each student of the Academy to make sure his/her behavior is above reproach. (p.10)

Similarly, the core values were also presented in the, Teacher' Handbook and Manual. Whether identifying good practices for teachers, or defining the code of conduct, the core values were expressed in the text of the teacher handbook. For example, under "Principles of Good Practices for Teachers" the text read, “...the teacher shall model integrity, curiosity, responsibility, creativity and respect to all persons as well as an appreciation for racial, cultural, and gender diversity (p. 3). Under the section, "Discipline," the Academy explained to the teacher that the objective of the Academy is to develop a foundation of self-esteem and self-knowledge in each student. The teacher is advised to make rules that are reasonable, well communicated and fairly administered. Moreover, the rules should demonstrate a "respect for others, students and staff, foster a spirit of mutual respect in which orderly behavior flourishes" (p. 13). Teachers and 
students were expected to adhere to and demonstrate the values of the school. The school's guidelines and rules were constructed around the core values including but not limited to the core values identified by CEP (2007).

Core values were found in the academic and Islamic studies curricula. The academic curricula for Taqwa Academy were adopted from the state of Florida State Standards. The standards for social studies, language arts and science state curricula for the third, sixth, eighth, and ninth through tenth grades were analyzed for language referencing the core values or traits. Respecting others was found in the social studies third grade curriculum as well as respecting property, helping neighbors and participating in community actions (see Appendix D). In language arts students were encouraged to identify values of others and to understand ethics as it was used in research, the media and digital technology (see Appendix E). In the state science standards for the eighth through 12th grades, ethical implications and ethical issues in the field of medicine were noted (see Appendix F). There were limited examples of core values found in the academic curricula, an adoption of the Florida State Standards. Respect for others and ethics were the most prominent values found in the academic curricula.

On the other hand, there were many examples of core values present in the Islamic studies curriculum course overviews as illustrated in Table 5. In addition to the core values identified by CEP, the school also had values that were not identified in CEP's principle list of core values. 
Table 5

The Character Traits Found in the Islamic Studies Curriculum Course Overview

\begin{tabular}{llll}
\hline Course Overview & \multicolumn{2}{c}{ Grade Levels } \\
\hline 3rd Grade & 6th Grade & 8th Grade & $11^{\text {th }}$ Grade \\
God-Consciousness & Obedience & God-Consciousness & God-Consciousness \\
Truthfulness & & Islamic ethics & Truthfulness \\
Steadfastness & Forgiveness & & Steadfastness \\
Faith & Faith & & Justice \\
Trust & Kindness & & Kindness \\
Work ethics & Charity & Charity \\
Patience & & Honesty \\
Respect & & Caring \\
\hline
\end{tabular}

Note. Collected from Islamic studies curriculum

For example, the curricula course overviews for third and sixth grade students stated that the students were taught to respect the Qur'an and the Prophet, to do good deeds and to share with others and to exhibit patience and strength in the face of hard times. An explanation of pedagogical strategies for teaching these traits were not provided in the course overview. In the introductory statement of the eighth grade Islamic studies curriculum course overview, character traits were not specifically identified but in the course objective, there was a reference to building Islamic character, which stated "To identify and build an Islamic character in the student through the study of Islamic ethics which is an essential component of any Islamic education curriculum." Character traits found in the 11th grade Islamic studies curriculum course overview included caring, steadfast, kindness, truthfulness, God-consciousness, charity, justice, honesty, and 
responsibility. Moreover, character traits are encased in the verses from the Qur'an, and according to the Islamic studies curriculum (see Appendix G), at the third level students were expected to memorize, understand, translate and explain the Quranic verses. It is possible that through this exercise students could also learn the character traits valued by the school. Appendix F also provides an account of what was taught in the Islamic studies curriculum 9-12 by levels of proficiency (in the Islamic studies curriculum, high school students were placed according to skill levels not grade level). The evidence from the Islamic studies curriculum indicated that the core values or traits for character education were present in the academic and Islamic studies curricula. Traits are important elements for implementing a character education curriculum.

The official curricula documents at Taqwa Academy supported the claim that core values were taught at the school. Handbooks for students and teachers, outlining the procedures and policies and the academic and Islamic studies curricula course overviews identified core values that were important to the developing students' character. However, it is the operational curriculum that demonstrated that these values were implemented. The following section explores the operational curriculum for evidence of core values at Taqwa Academy as defined by CEP.

Operational curriculum. Class room observations and other activities were observed for evidence of core values taught in the operational curriculum. During formal classroom observations the core values most often observed were respect, caring and politeness as illustrated in Table 6. It should be noted that values or traits observed at Taqwa Academy were not limited to the values or traits identified by CEP. This is also reflected in Table 6. 
Table 6

Character Traits Observed in the Classroom

\begin{tabular}{lc}
\hline Character traits observed & $\begin{array}{c}\text { \#of times } \\
\text { observed }\end{array}$ \\
\hline Respect & 5 \\
Caring & 3 \\
Politeness & 3 \\
Responsibility & 2 \\
Honesty & 2 \\
Cooperation/teamwork & 1 \\
Diligence, courage \& perseverance & 1
\end{tabular}

Note. Politeness and cooperation are not traits identified by CEP

An example of respect for rules and patience were observed in a sixth grade

English class where students were discussing ancient Egyptian religion. In their eagerness to participate some students did not follow the rules and blurted out the answers or made animal noises to get the teacher's attention. However, the teacher reminded students of the expected behavior:

I am very happy that you are excited, but what happens when we get too excited? Chaos, if you don't raise your hands. We can't have 19 people talking at the same time. I won't acknowledge you if you make animal sounds. This is an example of what not to do. (classroom observation, 2009)

As a continuous reminder to students a poster on the wall outlined behavior 
important to this class:

1. Wait your turn

2. Use polite words

3. Listen carefully

4. Cooperate with others

5. Show your appreciation

6. Give compliments.

Based on observed actions and interaction with students, it appeared that this sixth grade English teacher valued and taught respect and patience to her students.

Responsibility was observed during a visit to the third grade class. In an interview with this elementary teacher, she identified empathy and responsibility as core values of the school. She discussed the importance of teaching her students the value of being responsible (personal communication, 2009). Consequently, her third graders are assigned various duties to manage and maintain the classroom. Those duties included distributing books and materials needed for class as well as cleaning the room (class observation, March 23, 2009).

Caring for others was another value observed at Taqwa Academy. Students often displayed caring attitude for each other as well as for their teachers (informal observation). One example of caring was observed during a formal classroom observation of a sixth grade math class. Fatimah, a student skilled in math, was called on frequently by her classmates for assistance with their math problems and she assisted them without hesitation. During the time of this observation, Noor was having issues with a math problem so she approached Fatimah for help, "Can you help me," she asked. Without 
hesitation, Fatimah helped Noor and when the problem was finished Noor thanked Fatimah and returned to her seat while two other girls also sought Fatimah's help (classroom observation, March 27, 2009). Fatimah and other students like her with talent in a specific skill were charitable to their classmates by providing academic assistance.

Honesty was the topic of discussion in the Qur'an class when the teacher discovered that students were deceiving their teachers by pretending to have their menses so they would not have to pray. While the class recited from the Qur'an, they encountered the word "chastity." A student asked the meaning of chastity. The teacher stopped to explain chastity and honesty, punishment and reward. Maryam took this opportunity to discuss a prevailing issue existing among the girls regarding Jumah prayer. Consequently, instead of attending the Jumah services, they sit in a classroom with classmates and a teacher socializing during the time of Jumah. The teacher started the discussion by asking students about deception:

Teacher: "It is reported that some students are deceiving their teachers to get out of going to Jumah prayer. What is this sin?"

Students: "Lying," the students responded in unison.

Teacher: "When I heard that, I was furious. From now on, if you are sitting in Ms. Hall's class, you will write an essay."

By the Qur'an teacher attaching a consequence to girls who lied about their eligibility to attend group prayer, it conveyed to them that lying which represented dishonesty was not acceptable. The teacher continued her discourse on honesty pointing out to the students that they are more honest in worldly affairs than in their prayers. "You would rather be honest in dunnyah (worldly affairs) than honest in your prayers?" 
(classroom observation, May, 2009). Being honest is an important trait at Taqwa Academy; therefore, when the dishonest act was revealed, the teacher knew it was a problem that needed attention.

Extra-curricular activity. The extra-curricular activity provided the opportunity for the students to excel in something other than school work. This is where the performance values suggested by CEP are exercised. Values such as diligence, strong work ethic and perseverance were listed by CEP as performance values. At Taqwa Academy, students were afforded extra- curricular activities such as Qur'an competition where students had to memorize an assigned section of the Qur'an and recite it before an audience. This annual competition challenged diligence, work ethics and their ability to persevere. Other activities are the literary, science and social studies fairs, and competitions sponsored by the county. For these events students must complete projects and present them in the county competition (informal observation). The schools' extracurricular activities were fun and challenging. They demonstrated that the school provided opportunities for student to exercise performance values such as diligence and perseverance.

Hidden curriculum. Lessons learned implicitly without direct instructions are learned from the hidden curriculum (Schubert, 1986), and are usually manifested through the culture of the school. Lickona et al. (1997) suggest that the moral culture of the school is defined by the core values, which influence the practices and behaviors of the school community. Islamic practices are inherent in the culture of this school.

At Taqwa Academy not only did students learn core values through direct instructions, but they also learned core values through the hidden curriculum. The moral 
culture of the school created an environment that encouraged respect, and concern for others. For example, gathering in the masjid to pray for victims of 9/11 was a behavior influenced by the value of caring for others. "When we had 9/11, on that day, the whole school got together in the masjid and we had a moment of silence," the first grade teacher explained (F.Q., personal communication, May 12, 2009). Not only was the value of caring for others displayed through the act of praying for the victims, but for the students it was also an implicit lesson in caring for others.

Another example of learning to care for others implicitly was expressed by an elementary teacher, J.A., who described the empathic behavior of her students:

Not deliberate but maybe on a subconscious level. It is not something that we have big posters and banners, [it is] implicit. I think it is empathy. I find that the kids are very, when some [one] gets hurt, empathic. Even if they are arguing and they do not like this person, they do the bickering as well, but the minute that person is hurt or seriously needs some help, they are there.

In addition, a school administrator expressed that expectations, guidelines and school rules from the official curriculum, indirectly teach the core values honesty and respect:

Honesty would be one of those values, good character in presentation, physical presentation, emotional presentation, and wholeness... and that you should constantly be working on all parts of your character whether it is patience, respect for elders, self-control of one's desires, and self-control of one's anger. I think all of that is encapsulated with what expectations we have for students [in] the rules and guidelines. (M.M. personal communication, April 9, 2009) 
At Taqwa Academy, students learn core values through the hidden curriculum, Through the practices and behaviors of the school community, which embodies the culture of the school, students learn core values such as caring for others, honesty and respect. These core values are aligned with the core values listed by CEP; however the culture at Taqwa Academy fostered values not listed by CEP. The next section addresses the non-CEP core values of the school.

Core values found at Taqwa Academy. Research of the school documents revealed that Taqwa Academy's values extend beyond those listed in the literature review. As a religious school established upon Islamic philosophy, Taqwa Academy’s values extend to include religious values which are identified in the principles and practices of Islam. Among those interviewed, the values mentioned most frequently were prayer and modesty, which is connected to the Islamic value God-consciousness. CEP document described core values as "behaviors that can be observed in the life of the school..." (Lickona et al., 2007) It was common to observe students and members of the school community at prayer. It is a part of the school's daily routine, and every day at 1:30 p.m. the entire school gathers in the masjid to pray (the lower division prays earlier, before 1:30 p.m.). Prayer is printed in the school schedule and on Friday the day of Jumah for the Muslim community, the school stops to observe the community prayer. During this time the parents and other members of the community join the school community for a spiritual lecture and prayer (informal observation, 2009). The act of prayer is connected to the value God-consciousness, awareness of God at all times. In the definition of character education, a participant identified awareness of God at all times as 
an expected outcome of character education ( M. I., personal communication, May, 16, 2009).

Modesty can also be identified as a core value of the school. From an Islamic perspective, modesty means refraining from committing unlawful acts, shamefulness, and abstinence (Kassis, 1983). To teach modesty and to maintain a modest environment, students are required to wear uniforms that adhere to the Islamic guidelines for modest dress that prevent drawing attention to the physical body. Male and female teachers are not required to wear uniforms but they must also adhere to a modest dress code as described in the Teacher Handbook and Manual, " In keeping with Islamic customs and professional duties, all employees are expected to dress modestly" (p. 23, \#7). In addition to uniforms, to maintain an environment of modesty, the school also encouraged gender separation. Male and female students did not eat, play or sit together. During snack and lunch boys and girls had designated areas for snack and lunch. They also played in separate play areas, girls on the play ground and boys usually played ball in the open lot. In the classroom boys and girls were separated with girls sitting in the back or front of the room or either to the side left or right (informal observation, 2009).

Taqwa Academy core values were universal as well as consistent with the Islamic environment it represented. The school shared the core values identified by CEP as pivotal to character education and it possessed values that were pivotal to developing the Islamic personality that constitute good character as defined by Islam.

\section{Defines "Character" Comprehensively to Include Thinking, Feeling, and Behavior}

According to the CEP, this principle requires a school to take deliberate and

effective steps to help students understand, appreciate and practice the core values in their 
every day behavior. This section demonstrates evidence of thinking, feeling, and behavior in the effort to teach core values at Taqwa Academy.

Thinking. To teach thinking or understanding of the core values, CEP suggested that students should study and discuss the core values as well as observe those who serve as behavioral models for the core values. Also students should have opportunities to resolve problems involving values.

Study. The presence of core values in the academic and Islamic studies curricula indicated that the core values were studied by students at Taqwa Academy. Values such as caring for others, and respect, appeared in both curricula (see Appendix C, D, E, and F). For example in the Islamic studies eighth grade course overview, the stated purpose of the course is, "To identify and build an Islamic character in the student through the study of Islamic ethics, which is an essential component of any Islamic education curriculum." This statement indicated that Islamic ethics were valued by the school and it was considered an integral part of the curriculum.

Discuss. Although the term discuss did not appear in the Islamic studies curriculum, it was found in the Islamic studies course overview in some grade levels. The Islamic studies curriculum gave a broad view of the curriculum content without specific pedagogical details. To determine if the pedagogical strategy "discussion" was used to teach the core values, the Islamic course curricula overviews for the third, sixth, eighth, ninth, and 11th grades were analyzed. It was revealed that the term discuss was present in the objectives of the course curriculum overview for the third grade, but was not related to core values. In the sixth and eighth grades, the terms "state" and "know" were often used related to the core values. For example, a statement in the sixth grade course 
curriculum overview related to "giving" stated, "Students will be able to state the importance of kindness to zakah and sadaqah recipients" (people receiving charity). In the 11th grade, other terms, which could possibly lead to a discussion, were used to relate to core values such as "explanation' and "describe your feelings." However, "discussion" was found in the introduction of the eighth grade course curriculum overview where it was stated that students will engage in an in-depth study and discussion of Prophetic traditions and ahadeeth (sayings of Prophet Muhammad) Many of the ahadeeth of Prophet Muhammad were lessons in virtues.

It is possible that students engaged in discussion related to core values, but discussion as an actual pedagogical strategy related to core values was not found in the Islamic studies curriculum and found only once in a course curriculum overview. Likewise, in the academic curriculum the term discuss related to core values was not found but other terms such as explain and describe, which could possibly lead to a discussion, were present.

A discussion of the core value respect was observed in one class during classroom visits. In a level one Arabic class, the teacher led a discussion on respect. The lesson on respecting parents originated from the verse in the Qur'an that instructed the individual to show kindness to parents as well as all mankind (2:83). During the course of the observation, a student and the teacher engaged in the discussion of the importance of respecting parents and the different ways it should be done. Other classes may have had discussions of core values but such discussions were not evident during the time of my observations at Taqwa Academy. 
Behavioral models. At Taqwa Academy students were provided with behavioral models of how to live the core values. For example, teaching the life and practices of Prophet Muhammad and his companions was one of the strategies used to teach the students about core values. The Islamic studies curriculum for level five stated that the curriculum "Provides the opportunity for students to analyze various Islamic role models and their effect upon societies in which they live." According to Muslims, Prophet Muhammad and his companions are some of those role models from whom students are expected to learn the core values. For example, a statement from the third grade course curriculum overview encouraged students to, "Learn from the Prophet's example of patience." In the sixth grade course curriculum overview, students studied the life of Ummu Salamah, an important figure in Islamic history who served as a role model of patience and wisdom. The eighth and ninth grade course curricula overviews did not provide evidence of studying role models. In the 11th grade students were assigned a unit to study the life of Prophet Muhammad and his companions.

Behavioral role models were present in the third, sixth, and eighth grades social studies academic curricula (see Appendix C, D, and E); however no evidence of role models were found in the language arts/reading and science curricula of the grade levels. Likewise, no evidence of students given opportunities to solve problems related to values was found in the Islamic studies or academic curricular. Feeling, the second part to the comprehensive definition of character, is discussed in the following section.

Feeling. Developing a caring attitude, empathy, creating community and reflecting on life experiences were ways specified by CEP to teach students the emotional aspect of character. At Taqwa Academy, students were exposed to building a caring 
attitude and empathy through their community service, a requirement for graduation (Student Handbook and Planner, p. 13). A teacher reported that during the month of Ramadan, students collect money and food for needy members of society (M. W. personal communication, June, 2009). Thus, a caring attitude was fostered by providing opportunities for students to perform community service. However, there were no evidence that students were given time to reflect on the experience of giving. As it was related to the "feeling" component of defining character, students were encouraged to develop a caring attitude through their community service requirement, however the opportunity to reflect on the experiences of performing community was not evident in the data sources examined.

Behavior. Learning to act upon the core values is the third part of the comprehensive definition character. Students at Taqwa Academy were given opportunities throughout the day to act upon the school values. Some students were helpers in and outside of the classroom. During lunch the older students helped serve lunch to the younger students who received their lunch in the classroom. Other students assisted the media specialist during story hour with the younger students. The school valued prayer; therefore students act upon this value by making the prescribed prayer with the school community each day. In addition, the school valued modesty, thus students were required to wear uniforms to school, which gave them practice in modest dress even if they did not practice it away from school. There was evidence that at Taqwa Academy students were given opportunities to act upon some of the core values of the school. The next principle discusses the approach to character development. 


\section{Uses a Comprehensive, Intentional, and Proactive Approach to Character \\ Development}

The elements of this principle as described by CEP state that character education is:

1. Strategically planned at all grade levels

2. regularly integrated into academic content

3. intentionally and proactive a priority in a all classes, and

4. infused throughout the school day to include sports and extra-curricular activity.

Strategic planning. During formal or informal observation there was no time where a strategic planning session for character education was observed. There were meetings to discuss discipline issues and how to address them and there were division meetings where the academic and Islamic studies teachers met separately. All divisions gathered for general staff meetings usually led by the president of the school. Although a strategic planning session for character education was not observed, through the handbooks for teachers and students, the school's expectations were explicitly communicated to the students and faculty. In these documents, character expectations were addressed. The expectations were issued at the beginning of the year in the form of the school's rules, policies and procedures. Providing the expectations in writing and issuing these documents at the beginning of the year, indicated that the school intentionally and proactively communicated the guidelines to the students and teachers.

Integrated into academic content. Did this school regularly integrate character education into curriculum content? To find evidence of regular integration, the academic 
curricula and class observations were examined. Character traits were present in the academic curricula as illustrated in Appendix C, D, and E. However, only two incidences were observed where character education was explicitly integrated into the lesson of an academic class. To determine if the school regularly integrated character education into the content of the academic core classes, academic classes would have to be observed more often than occurred in this study.

Classroom implementation. One of the CEP principles of character education is that it should be an intentional and proactive approach in all classes. To investigate this component of the principle, class observations were analyzed for the traits and how they were taught. In addition, the application of pedagogical strategies as they relate to the traits was also analyzed. The word intentional was changed to explicit to make it easier to identify the observed action. Intentional is abstract and difficult to observe. Therefore I used explicit and implicit the opposite of explicit. The term incidental was also applied to the observed actions that did not fit explicit or implicit. The terms were defined as follows:

Denotative definition: Explicit: "fully and clearly expressed or demonstrated" (explicit, dictionary.com)

As used in this study: Explicit: a character trait is deliberately taught through a lesson or planned activity; A pedagogical strategy is deliberately used to teach a character trait.

Denotative definition: Implicit: "potentially contained" (implicit dictionary .com) 
As used in this study: Implicit: The potential or possibility of learning a character trait is evident because of an activity, gesture or lesson. Denotative definition: Incidental: "happening or likely to happen in an unplanned or subordinate conjunction with something else" (incidental, dictionary.com)

As used in this study, Incidental: A character trait is discussed, modeled or explained as a result of an act, mishap, or misbehavior on the part of the student.

To analyze the character traits or pedagogical strategies that resembled those found in the literature, I applied the following questions: (a) was this trait taught explicitly in that it was a part of the lesson or discussion, (b) or was the potential for learning the trait possible as a result of a gesture, activity, but not necessarily discussed, (c) or was the trait discussed because of a mishap, behavior (desirable or undesirable) or gesture. These questions were applied to each observed trait and pedagogical strategy and were presented in the following section.

Traits. As illustrated in Table 7, the trait respect was taught explicitly and implicitly by the classroom teachers. 
Table 7

Character Traits Implementation

\begin{tabular}{ll}
\hline Character traits observed & Implementation \\
\hline Respect & Implicit/Explicit \\
Caring & Incidental \\
Politeness & Implicit \\
Responsibility & Explicit \\
Honesty & Incidental/implicit \\
Trustworthiness & Implicit \\
Diligence, courage \& perseverance & Explicit
\end{tabular}

Note. From field notes taken during classroom observations

An explicit lesson for respect was observed once during classroom visits, whereas the implementation of the trait respect most often occurred implicitly during observations. The trait respect was typically observed not as a planned activity or lesson, instead, it was usually implied in the way the teachers spoke or interacted with students. An example of implicitly teaching respect happened in the sixth grade Islamic studies class. C. S., the middle school division head, entered into H. H.'s class to instruct him on how to dismiss students due to the rain.

Several students interrupted the two teachers by making comments into the teachers' conversation. H. H responded:

H. H: To C. S., "Are you talking to me?"

C. S: "Yes, you." 
H. H.: To students, "Oh, okay. Sorry students, he is talking to me. Continue, Br. C. S.”

Although the teacher did not use the term respect, the expected behavior was implied not directly taught. This interaction with the students presented the potential to teach students to respect others by not interrupting when they are engaged in a conversation. Another example of implicitly teaching respect was the gesture made by the world history teacher M. M., also the head of the high school division. The incident occurred when he was late for his last period class. He arrived apologizing and explaining to the students the reason for his tardiness (classroom observations, M. M., May, 2009). This gesture of apologizing to the students conveyed the message that he respected their time. Although the gesture apologizing was not a planned lesson in respect, it had the potential to teach respect as it relates to another person's time.

There was one occasion during a classroom visit that an explicit lesson in respect was observed. In the Arabic level one class, G. A., who was substituting for an absent teacher, taught a planned lesson on respecting parents. As discussed previously, the teacher presented a lecture addressing the importance of treating parents with respect at all times (classroom observation, G. A., May 2009). He used as his focus the verse from the Qur'an (2:83):

And lo! We accepted this solemn pledge from [you,]the children of Israel: 'You shall worship none but God; and you shall do good unto your parents and kinsfolk, and orphans, and the poor; and you shall speak unto all people in a kindly way; and you shall be constant in prayer; and you shall spend in charity. 
This lesson was planned and explicitly implemented to teach respect. Although other concerns were included in the verse, during that observation, the teacher focused on respecting parents.

Responsibility is the next most frequently observed trait. J. A., the elementary third grade teacher deliberately wanted students to learn responsibility; during her interview she stated, "I am a firm believer in responsibility" (J. A. interview, April 22, 2009). When observing her class, I noted that the activities that her students were engaged in reflected her effort to teach responsibility. For example, the students in her third-grade class were made responsible for the plants in the class room, cleaning the cafeteria after lunch, and passing out and putting away class materials for their classmates (J. A. classroom observation, 2009). An example of an implicit lesson of responsibility was observed in N. K.'s chemistry class where two students were given the task of assisting with the lab experiment. They retrieved the lab equipment from the storage cabinet and placed each item on the designated tables. When the experiment was completed, they cleaned and returned each item to its respective place (N. K. classroom observation, March 24, 2009). This was an implicit lesson in responsibility for those two students. By assisting with the lab experiment, the students had the opportunity to learn responsibility; although the teacher did not discuss being responsible, the potential to learn responsible behavior was present. Caring was another trait observed during classroom observations.

As mentioned earlier, J. A., the third-grade teacher assigned students various duties in the classroom. In addition to teaching responsibility by assigning these tasks, she also taught her students to care. For example she taught them to care for classroom 
plants by giving the students the task of watering and feeding the plants. She also taught them to care for the eating environment by facilitating their cleaning the cafeteria after they and other classes finished eating lunch. According to J.A., teaching students to care about the environment whether it is a plant or the eating space was done explicitly. On the other hand, the Qur'an teacher implicitly taught the trait caring through the gesture of assigning an advanced student to mentor a new student in the sixth grade Qur'an class. During the class she stated, "Yusef, move down to Rahim because he is new to Arabic. Rahim you are doing wonderful, I want you to keep it up" (classroom observation, March 26, 2009). From this gesture students had the potential to learn to take care of others who may be disadvantaged due to circumstances such as a being in a new environment. Another example of caring was demonstrated in the Arabic senior level class. S.H., the Arabic teacher, implicitly taught caring when he inquired about a student's injured finger, "How's that finger? Can you write with it now?" He inquired with a smile (classroom observation, March 30, 2009). From the teacher's show of concern for the student's well being, the students also could possibly learn to show care and concern for others. In addition to caring, the trait politeness was observed during classroom visits.

Politeness involved thanking people and saying please when asking. Teachers often thanked students when they completed a task and they said please when they asked students to do something. In J. A.'s class, students learned to say thank you from a classmate. The incident occurred when the teacher was distributing assignment papers to the class, one student said, "Thank you." The teacher's facial expression was of surprise and she responded in a pleased tone, "You are welcome." After that interaction, other students began to say "thank you" after receiving their papers. In the same class, when 
the teacher passed out candy from the fun basket, one student said "thank you" to which the teacher responded, "Oh, only one thank you." After that comment, others who came up to receive their candy said, "Thank you" (classroom observation, J. A., March 23, 2009). The trait politeness was taught incidentally because it only occurred as a result of the behavior of a student who actually demonstrated politeness and other students responded based on the teacher's reaction. In other classes politeness was implicitly taught as well. For example, C. S., the social studies teacher and middle school division head, thanked a student for reading a passage from a book and M. R., the ninth-grade English teacher, thanked students for reading their narratives out loud. These were examples of implicitly teaching politeness because the teacher modeled the behavior and did not specifically teach it. Thus, the potential to learn politeness was possible.

This section provided examples as evidence that the core values respect, responsibility, caring and politeness were implemented explicitly, implicitly or incidentally as observed in the operational curriculum. Therefore, it appeared that at Taqwa Academy some teachers periodically intentionally and proactively taught character based on the explicit, implicit and incidental implementation of lessons that included character traits or core values. The next section discusses the infusion of character education in other aspects of the school.

School-wide implementation. Character education is infused throughout the school day to include sports and extra-curricular activity. Every Wednesday after prayer students (boys and girls) were given 1 hour to play soccer, volleyball or football. These games were informal sporting activities. During lunch time, students also played games and often time the male students played sports with the male teachers (informal 
observations). These games provided an opportunity for students to learn and follow rules.

Extra- curricular activities included field trips, clubs activities, and competition. Once a year students took a major field trip to a place selected by the Student Government Association (SGA). Clubs offerings were limited but the younger students had the 4-H club and the older students who met the requirements were invited to join the National Honor Society (NHS), which required students to have and maintain good character. Students were given the opportunities to compete in various competitions held at the school. There was the Qur'an competition, a school held competition and the county-wide spelling bee competition as well as the science, social studies and Literary fairs.

The comprehensive, intentional and proactive principle of character education was observed at Taqwa Academy in some areas but not in others. For example, there was no evidence of strategic planning for character education at all grade levels, and evidence did not verify that character education was regularly integrated throughout all classes; however, integration was observed in two classes. The classroom observations revealed that some character traits were taught explicitly, whereas others were taught implicitly or incidentally. Furthermore, there was evidence that character education was infused throughout the school day to include sports, extra-curricular activities and clubs for students.

\section{Creates a Caring School Community}

According to CEP, a school creates a caring community by helping all of its members form caring attachments to one another. Caring relationships exist among 
students, between students and staff, and among adults within the community. At Taqwa Academy through formal and informal observations and participants' responses, evidence of caring relationships was observed.

Among students. Caring relationships among students were observed during informal observations. Students were observed tutoring within and across grade levels. Students who were skilled in particular areas of math tutored those who needed extra help. For example, after regular school hours, one student in the senior class tutored younger students in math. Middle and high school students assisted teachers in the elementary and pre-school classes during the school day. There was also an incidence observed that exhibited a non-caring behavior as well. This incident was addressed by an adult to help students in forming a caring relationship. For example a middle school teacher described an incident where a sixth grade girl complained that two girls from the sixth grade read a private diary entry from her diary and shared it with other girls who in turn, made fun of her. The teacher addressed the problem immediately, "I had to stop class and just give a few minutes explaining that it is not proper to read someone's personal business and how that can affect that person"(M. R. personal communication, May 13, 2009). She said the girls later apologized for their behavior. Even though this was an incident of an uncaring act, the issue was addressed, which is evidence that the teachers made an effort to foster caring relationships among students. Another teacher expressed the importance of teaching students to care about students with special needs. She explained:

The teacher's job is to train the students too, when a handicapped child or a special needs child is coming in or is already there; how you deal with them. So, 
teachers need to prepare students, too. The students, no matter what age or what level, need to know also how to deal with those kinds of situations with students. (F. Q. personal communication, May 12, 2009) Creating caring relationships among students was an observed principle at Taqwa Academy as evident through informal observations and participants' interview responses.

Between adults and students. CEP outlined criteria for fostering caring attachments between adults and students to include: teachers attending school events, the school making provision for students and teachers to meet in social settings, and teachers providing time for extra help in academic work. Starting with school events, teachers at Taqwa Academy were usually in attendance at most school events, including graduation, award ceremonies, and competitions. Some teachers also attended the basketball games of the recently organized basketball team who traveled to play because the school did not have a gym. Teachers were required to attend the graduation. However, former staff members, who were not required often attended the school's graduation. This was an indication that a bond was established between the teachers and the students they taught. The school made provisions for students and teachers to meet at social settings. For example, at the end of the year, teachers, former graduates and the graduating class were invited to a local restaurant for dinner and recognition of the former and the present graduates.

Another event that brought students, staff and community together was the iftar, a dinner partaken during the month of Ramadan to break the fast; staff, students and the broader community attend this school sponsored event. The relationship was also created between student and teachers when teachers provide extra academic help for struggling 
students. At Taqwa Academy, teachers provided tutoring to students in the afterschool program and before school as well as on the weekends. In the case of Taqwa Academy, teachers also spent time providing extra help in Arabic and Islamic studies during those times as well (informal observation).

Among adults within the community. According to CEP, the staff should make an effort to develop respectful and caring relationships among themselves and well as form positive relationships with students' parents and guardians. There are traditions in the Islamic culture to help create caring communities. One of those traditions is saying a prayer for the person or a family member who may have suffered a loss or may have an illness. This prayer was offered after Dhur prayer on many occasions when it was known that someone was experiencing loss or illness (informal observations). It was the school community's gesture to make the person aware that the school cared and empathized with that person. Also prayers were sent by electronic mail by individual teachers to those suffering. The attention was also given during happy occasions such as weddings and the arrival of new babies. These activities fostered a positive relationship among the staff.

Parents were an important entity of the school; therefore the school made an effort to establish positive relationship with parents by encouraging teachers to become a part of the Parent Teachers Association (PTA) as stated in the Teacher Handbook and Manual:

Teachers are encouraged to be a part of the PTA and attend its meetings and functions. PTA provides the teachers with the opportunity to meet with the parents and talk with them in an informal environment. It also fosters the 
relationship between the teachers and parents and helps to coordinate the efforts of the teacher and the parents to achieve the best result for the students. (p. 8) Also in the handbook, teachers were instructed on how to handle students' illness and loss:

If there is ever a death in the family of student in your class, please notify the office as soon as possible. Also if there should be a real serious illness of a student in your class or anyone in the immediate family, please let us know. If the student is hospitalized you should visit, if allowed by the doctor. (p. 42)

Based on the events and traditions of the school, it appeared that the school had in place ways of developing and keeping a caring relationship with the student, staff and parents.

\section{Provides Students with Opportunities for Moral Actions}

The CEP lists the following as criteria for providing students with opportunities for moral actions: School sets clear expectations for students to engage in moral action, school provide students with repeated and varied opportunities to engage in moral action within the school, the school provides students with repeated and varied opportunities for engaging in moral action in the larger community.

School set clear expectations for students to engage in moral action. The expected behavior outlined in the student handbook is an indication that the school made an effort to engage students in moral action. Regarding civility and responsibility the following rules and guidelines were listed in the Student Handbook and Planner: 
Classroom: (a) Be respectful in behavior that allows the flow of the class activity

(b) Be in class on time with the necessary materials and be prepared to begin work [responsibility]. (p. 7)

Prayer: During prayer, disciplined behavior must prevail to allow sanctity and the purpose of salah (prayer) to remain prevalent [self-discipline]. (p. 8)

Cafeteria: (a) Be respectful and cooperative and (b) Clean places at the tables and discard trash [responsibility]. (p. 8)

Inside the classroom: Classroom behavior should always contribute to an atmosphere that supports learning, namely: (a) Be in class on time with all of the necessary materials, and be ready to begin work. (b) Pay attention to teacher and do not talk in class (c) Be respectful in behavior that allows the flow of the class activity, whether it is a lecture, discussion, or lab. (pp.7-8)

Outside the classroom: (a) Students are to greet fellow students and faculty members with as-salaamu-alaikum [a prayer given in the Arabic language that means "may the peace that only God can give be upon you"] and (b) Behavior outside the classroom will be courteous, respectful and considerate toward others. (p. 8)

Other guidelines addressing civility were the guideline emphasizing mutual respect for each other; students value personal belongings and respect the possessions of others and will show concern for proper use of school property. Furthermore, the Academy guidelines state that, "the Academy does not tolerate profanity, cursing, and abusive language. The use of such language demeans both the student and the school" (p. 8). The school's rules and guidelines explicitly detailed the expectation of moral 
behavior. The expectations for civility and responsibility as well as community service were delineated in the student handbook.

CEP stated that the school must provide opportunities for students to meet the expectation of moral behavior within the school community and the larger community. Within the school, Taqwa Academy provided opportunities for students to tutor other students by providing them with a place and time to tutor. The students also had an opportunity at self-government with the Student Government Association, an organization endorsed and sponsored by the school. Within this organization, students plan activities for the student body including initiating and planning field trips for students (former SGA president, personal communication, June, 2009). Similarly, Taqwa Academy provided opportunities for engaging in moral action in the larger community by encouraging students to perform community service. As discussed above, expectation regarding community service is stated in the Students Handbook and Planner that students were required to complete at least 75 hours of community service before graduation (p. 13). The school facilitated the students completing their hours by allowing the community organizations to recruit students to volunteer at community activities and programs.

Students were encouraged to collect money and food for needy families during the month of Ramadan and at other times (M.W. personal communication, June 2009). After performing a community service, CEP suggested giving students an opportunity to individually and collectively reflect on moral action. However at Taqwa Academy, evidence of student given opportunities to reflect through discussion or journal writing was not observed, informally or formally. In summary, Taqwa Academy explicitly stated 
expectations for student moral actions as well as provided opportunities for students to engage in moral action; however, providing students with the opportunity to reflect was not observed.

\section{Includes a Meaningful and Challenging Academic Curriculum}

Challenging and meaningful courses and the intersection of academic content and "character connections" were the components of this characteristic from CEP. The components of this principle included meaningful curriculum, challenging curriculum and finally identifying the intersection of the academic content and character education. This section examines Taqwa Academy's curriculum for those components.

Meaningful curriculum. Providing a meaningful curriculum according to CEP includes active teaching and learning methods such as cooperative learning and problemsolving approaches. Examples of these pedagogical strategies as well as others were observed at Taqwa Academy during classroom observations as illustrated in Table 8 .

Table 8

Pedagogical Strategies Observed During Class Observations

\begin{tabular}{lc}
\hline Character building strategies & \#of times observed \\
\hline Modeling & 7 \\
Integration & 2 \\
Storytelling & 2 \\
Lecture & 2 \\
Posters on wall & 1 \\
Social learning & 1 \\
\hline
\end{tabular}

(table continues) 
Table 8 (continued)

\begin{tabular}{lc}
\hline Character building strategies & \#of times observed \\
\hline Explanation & 1 \\
Cooperative learning & 1 \\
Questioning & 1 \\
Problem-solving & 1 \\
\hline
\end{tabular}

Cooperative learning was observed in the Qur'an class where students were divided into teams to answer questions. The teams competed to earn points for getting the correct answer. For some students being a team member proved to be quite challenging. The day of this observation, for the sixth grade class, the Qur'an teacher set up a game to review ayah or verses from the Qur'an, the scripture revealed to Prophet Muhammad. The teacher assigned teams, with boys and girls competing on opposite teams. The students were instructed to consult team members before answering questions. The emphasis was on cooperation, working together as a team. The first question was posed and the teacher reinforced the rule by asking the teams, "Did you agree before answering?"A question was given and a student spoke out the answer without consulting her teammates. The teacher quickly reminded them, "I said this is teamwork. Asma you have to go to your team before answering. I want you to give them a chance to think it over." A wrong answer was given from the boys' team. A member of the team protested. Student: “They made a mistake.” Referring to his teammates.

Teacher: "I said this is team work."

Student: [to teammate who gave the incorrect answer] "You should've discussed it with us." 
The teacher for this class gave her students an engaging lesson in team work. Problem solving and experience-based strategies were implemented when students prepared for the science fair. These approaches were not observed in all classes. It is possible that the teacher used these strategies but they were not in use on the day of observation. The next section describes how the school provides students with a rigorous curriculum.

Challenging curriculum. The Academy offered Advanced Placement (AP) courses in math, science, English and social studies. These courses were offered as an after school program and students who were committed remained after school to take them. In a letter to potential donors the president of the school lauded the success of the school's rigorous curriculum. He stated:

Alhamdulillah, the Academy is unique by virtue of its mission to produce students with Islamic character that excel academically in all disciplines. We have produced Ivy League students and district winners in science, social studies and literary fairs and AP scholars. (personal communication, letter 2007)

The fact that the school offered Advanced Placement courses and high level math and science courses indicated that the curriculum is rigorous and challenging.

Intersecting Curriculum. Regarding the intersection of academic content and character education the evidence from classroom observation revealed that character education was integrated explicitly into two academic classes during the time of observation. Most events of character education occurred implicitly in the classroom as illustrated in Table 7. Consequently, it is possible that there was some intersection of character education and academic content at this school. However there are dissenting voices that were of the opinion that character education takes a back seat to academic 
attention. There were some participants who believed the intersection of academic content and character connection was missing the mark at Taqwa Academy. They felt that there was too much emphasis on academic and not enough on character development as expressed by an Islamic studies teacher, "Unfortunately, I would say that more emphasis here is placed on academics than on the Islamic character education" (S.H., personal communication, April 28, 2009). A math teacher made a similar point, "I think there is more focus on students getting into college level than the stress on being a good person" (O. I. personal communication, April 30, 2009). These teachers were dissatisfied with the discrepancy in the value placed on character education and academic education.

Nonetheless as it is related to the components of this principle the evidence revealed that the teachers employed some meaningful pedagogical strategies and that the school offered a rigorous and challenging curriculum. Although evidence revealed that there was some intersection in academic content and character education, some participants felt the school did not place enough emphasizes on character education. The next principle addresses the school's efforts to provide opportunities for self-motivation for students.

\section{Strives to Foster Students' Self-Motivation}

Schools of character, according to CEP, provide meaningful opportunities for students to reflect, problem-solve and to do restitution. Schools of character also help students to understand desired behavior, and become aware of how their behavior affects others. These schools also help students build the character strengths needed for the future. 
Understanding why. An example of helping students to understand a desired behavior was observed in an Islamic studies class when a student sneezes. In the Islamic culture and also in some other cultures, a response is given when someone sneeze. In the Islamic culture, the response is a prayer. After a student sneezed in an Islamic studies class, the teacher explained the proper Muslim response to a sneeze, which is a prayer, and the purpose of the prayer. According to Ryan and Bohlin (1999), if educators want students to internalize values they must be given explanations along with the facts. Explaining the response to the sneeze was an opportunity to foster students' selfmotivation. If a student understands why and accepts the practice, perhaps he/she will be motivated to follow that practice. Another self-motivation activity was observed during a class observation with the same teacher's Islamic studies class. Near the ending of the class period, a group of students entered the room and walked to the storage shelves in the back of the room to put away their books. It was an obvious disturbance to the class. The teacher met the intruding students at the storage shelves and asked. "Is there something wrong here?" And one of the students responded, "We are not supposed to enter." And, they turned and left the room lugging their bags with them. The teacher did not scold or reprimand, he simply asked the question to give them an opportunity to reflect on their behavior and to realize that it was wrong.

Talking and explaining rules to students were noted in the minutes of a faculty meeting, the official of the meeting stated: "Teachers should talk to students, when they break the rules and if they don't comply, teachers need to write incident reports for the student breaking the rule (staff meeting minutes, September 18, 2007). Teachers were reminded to talk to students before executing punishment. Talking to students would 
help them to reflect on their misbehavior and to identify the appropriate behavior or the behavior that is reflective of Muslim character.

Behavior affects others. The incident mentioned earlier with the girls and the diary was an example of helping students to recognize the effect of their behavior on others. The sixth grader was upset at having her privacy violated and the English teacher emphasized that aspect of their behavior to the girls. She made them aware that their behavior hurt another person. Helping students become aware of character strength needed for the future was not observed. Students often recognized the academic skills needed for the future such as math reading and writing skills but a discussion or reminder of character skills needed for the future was not observed during informal or formal observations. Taqwa Academy's efforts to foster students' self-motivation were observed during class observation in some classes. Students were given explanations of desired behavior as well as made aware of the effect of their misbehavior on others. This principle was not observed in every class; however the fact that it was observed in some classes indicated that some teachers were aware of it. The next section addresses professional development for character education.

\section{Engages the Staff as a Learning and Moral Community That Shares Responsibility for Character Education}

CEP asserts that schools of character involve all school staff in learning about, discussing and taking responsibility for the character education. This section revealed findings from the analysis of participants' responses to interview questions regarding professional development for character education. Also included is evidence of modeling the core values of the school as well as staff reflection on character education. 
Learning about character. Staff at Taqwa Academy was not involved in learning about character education in a formal venue such as workshops or classes. One of the protocol questions specifically asked "how does professional development in this school enhance your ability to teach character?'Participants' responses were similar in that most explained that they did not receive training or professional development in character education. For example, an elementary teacher stated, "In this school so far, I do not think we got this kind of training" (F. Q. personal communication, May 12, 2009). A high school teacher's response was similar. The response was:

I do not think so. That was something I was discussing even last night with the head of the Islamic studies department- is that we have to create workshops...We have to create our own workshops where we can talk about building character and Islamic character for the students and to develop teaches also, to develop their character ( Q. I., personal communication, May 13, 2009).

From the perspective of the participants, the school did not provide professional development in character education and according to one participant, there was limited opportunity to discuss the needs of character development for students. Although teachers did not receive professional development in character education, they were able to model the core values as evident in the following section.

Modeling core values. Teachers at Taqwa Academy assumed responsibility for modeling the core values. During classroom observations, modeling was the pedagogical strategy observed most often, as illustrated in Table 8. Moreover, in their interaction with students and faculty, most teachers modeled cooperation, mutual respect, responsibility compassion and modesty (Informal observation). For example in modeling modesty, 
most teachers modeled modesty by adhering to the school's dress code of loose fitting and non-revealing garments. And most women wore a head covering to cover their hair. During prayer time, teachers and students prayed together, except for non-Muslim teachers who were neither expected nor required to perform prayer

Shared values and norms. At the time of this study, only four members of the teaching staff were non- Muslim. Other members of the teaching staff shared the same belief system as the students. Therefore the traditions and practices were adhered to by most of the staff as well as the students. Consequently, faculty and students pray together as mentioned in the previous section, attend jumah together and observe the Ramadan fast as well as the Eid celebrations together. Non-Muslims were not required to pray, attend Jumah, or observe Ramadan.

Reflection on character education. There was no evidence that supported faculty's reflection on character education, collectively or in small groups. In fact, one participant, E.T., expressed that there was a lack of discussion among faculty about character education during faculty meetings. When asked if there was a time of the year that faculty discussed areas of focus for character education, she asserted:

Not specifically, I think there is a lack of faculty dialog. Most of the staff meetings and professional development-type meetings we have are very information-directed sessions that leave little opening for discussion or dialog for teachers to set priorities and to discuss teamwork and how to get to these issues. (personal communication, April 19, 2009).

The evidence revealed that Taqwa Academy did not provide opportunities for 
faculty to reflect on character education as prescribed by CEP. Moving the focus from the faculty to the leadership, this next section examines the data sources for evidence of how the leadership supported character education initiatives in the school.

\section{Fosters Shared Moral Leadership and Long-Range Support of Character Education Initiative}

For this principle CEP suggests that the school should establish a character education committee comprised of staff, parents, students and members of the community. In addition, CEP suggests that students take a leadership role in the character education effort. At Taqwa Academy, based on the function of the Islamic studies division and how they were perceived by the participants of the school, the teachers in the Islamic studies division were considered the leadership group for character development. The president of the school and the board developed a mission statement that directed the school to teach "the principle and practices of Islam," meaning that the principles and practices of Islam will produce students with Islamic personalities. Having an Islamic personality is exhibiting Islamic values and attitudes, which include honesty, fairness, respect, caring for others and self-discipline. Therefore, the Islamic studies division teachers were considered the character education committee. However, neither parents nor other staff members were a part of the Islamic studies division meeting. Moreover, there was not a committee at Taqwa Academy explicitly designated to plan and monitor character education.

According to CEP, students should also contribute to the character education efforts in a leadership capacity through classroom monitoring, safety patrol, student government, peer mediators and peer helpers. As observed informally and formally, at 
Taqwa Academy, students participated in the safety patrol, student government and they served as peer helpers. Long-range support according to CEP, include the school leadership providing adequate staff development and planning time for character education. At Taqwa Academy adequate staff development or planning explicitly designated for character education or planning was not provided.

Taqwa Academy partially met the criteria for this principle. By default, the Islamic studies division could be considered the character education committee because it was through the Islamic studies division that character education was taught. There was no evidence that the teachers from the academic division and parents were a part of the character education committee. However, students were involved in a leadership capacity at the school. Consequently, the evidence revealed that the leadership of character education at Taqwa Academy for this principle was partially met. The next section provides evidence of the school forming partnerships in character education with parents and community.

Engages Families and Community Members as Partners in the Character-Building Effort

Engaging families. Involving parents in character development is paramount according to the literature (Berkowitz \& Grych, 1998; Smetana, 1999). At Taqwa Academy, parents' involvement in character education is limited to discipline and academic achievement. When students misbehaved or their academic performance fell below expectations, parents were called and sometimes face-to-face meetings were held to discuss the child's discipline issue. However there was no evidence that Taqwa Academy engaged parents at the level suggested by CEP. For example, there was no 
evidence that the school provided workshops for parents on parenting skills. However, parents were an integral part of the classroom activities especially during the holiday celebrations and the Cultural Day activities. Parents prepared the food and ensured that the child was prepared to participate in the Cultural Day activities (informal observation). However, unless parents were members of the school board, they were not engaged in strategically planning character education initiatives.

Communicating with families. CEP suggested that the school communicate with parents providing suggestions and activities to help parents reinforce the core values. Communication with parents was stressed to the teachers and printed in the handbook, "Duties and responsibilities of a teacher is to confer with parents when requested by the principal to do so or when he/she feels a need" (p. 5). In a staff meeting, teachers were encouraged to increase parent conferences and document them (minutes, Sept. 2007). Since the document did not specify what information to share with parents during the conference, one can only assume that the teacher offered suggestions to the parent regarding helping the child to improve his/her behavior, which in turn could reinforce the core values of the school. However, it is not explicitly stated that teachers were to reinforce the core values of the school with parents. The school's letters of communication with parents were done to inform or remind parents of school events. Periodically, the school published and distributed brochures and newsletters to parents and the broader community announcing the school's programs. These communications were not directly related to character education.

In one brochure there was evidence that the school provided suggestions to parents that could reinforce the school's core values of diligence, responsibility and 
caring for others. The brochure, The High School Game Plan, was a guide for parents and students to complete a successful program of studies at the school. Although in this publication academic success was the main focus, character education was implied. This publication provided parents and their student with 9 to 12 steps that could ensure the success for their child at Taqwa Academy. In the freshman year, students were encouraged to "carry the maximum workload allowed." All steps of The High School Game Plan publication encouraged students to take responsibility for their progress during any given year of their study. The implications were that students must be diligent and responsible to master the high school years. The only step that was relatively explicit to character building is the step referring to community service hours, a requirement for all public high school students in the state of Florida. At the freshman level, students were encouraged to begin community service, to continue in the sophomore and junior years, and in the senior year students were advised to review their community service hours, making sure that the hours were complete.

To facilitate academic success, the school publication of a step by step guide to success implied that the performance core values of diligence and responsibility were needed to meet these requirements. Although community service was not an academic activity, it was a requirement for graduation and to qualify for a state scholarship.

Communicating with the broader community. The school communicated with the broader community, recruiting the community's support. Taqwa Academy reached out to the community for fundraising and also to provide students with an avenue to perform service projects. The president of the school solicited funds from prominent members of the community. He also allowed organizations to recruit student volunteers 
to work special events for community service hours. The school also applied for grants related to character development from the Department of Education. For example, the school applied for the Abstinence Education grant, the Martin Luther King Day Diversity Project in collaboration with One Planet United and Florida Institute for Peace Education (FIPE) to establish a day of learning principles of peaceful non violent resistance. Other grant applications included The Sun Sentinel Diversity Grant and the Broward Beautiful: Environmental Enhancement of Public Area grant. These grant applications were evidence that the school sought assistance from the broader community in support of the school's character education program. Although parents were not members of a character education committee at the school, Taqwa Academy made an effort to engage parents and the community as partners to support activities that directly and indirectly developed student character. The next section investigates Taqwa Academy's system for assessing the character education initiatives in the school.

\section{Assesses the Character of the School, the School's Staff Functioning as Character Educators, and the Extent to Which Students Manifest Good Character}

Assessing the progress of character education using both qualitative and quantitative methods is an important part of a character education program according to CEP. The outcome should be measured in three areas: character of the school, the school staff's growth as educators and student character. They suggest that schools use surveys to measure school and staff progress and questionnaires to measure student character progress. At the time of this study, there was no evidence that Taqwa Academy had used these formal methods or instruments to measure the progress of their character education initiatives. Unlike the academic programs, where there was an end of the year test and a 
standardized test, there was no end of the year test or performance indicator that measured a student's or the school's progress in character development.

An administrator of the Academy acknowledged, when asked if there were any measurement for character education the response was, "No, besides personal observation and seeing success stories of graduates who have left the school and seeing students who are continuing in jobs after school" (M. M., personal communication, April 9, 2009). This participant was aware of students who had improved in their behavior since enrolling in the school, but because there were no formal assessments for character education, the participant could not say what progress had been made school-wide among all students. Another participant also observed improved behavior among certain students who had entered the school with negative behaviors, "We did see some dramatic behavioral changes in some students who entered the school from some rather rough public schools and two years later they were a lot more refined in their manner and in their conduct" (E. T. personal communication, April 19, 2009). The participant continued by stating, "We do not have anything very systemic in place for that" [measuring character education]. Similarly, another participant's response was, "Formally, no. There is no specific metrics to measure that, but informally we look at a student, whether the student prays or not; whether the student is involved in the community; whether the student stopped using profanity, whether the student does not use drugs, alcohol or smoking, whether a student is very respectful in the community, how the community looks at him" (Q. I., May 2009). This participant agreed that there was no formal measurement but he noted that there was an informal measurement and he gave the criteria by which progress in character development is measured informally. According to 
CEP, assessment reveals how the character education initiatives are developing; it is used to monitor, promote and plan character education efforts. Evidence of the assessment of character education was not present at Taqwa Academy.

In summary of the 11 principles, the following table (Table 9) displays evidence of CEP's Eleven Principles of Effective Character Education found in the Data analyzed from Taqwa Academy.

Table 9

How Character Education is Implemented at Taqwa Academy

Data Sources

CEP's Effective Principles of Character Education

\begin{tabular}{lll}
\hline Particip & Docum & \\
ant & ent & Observation \\
Intervie & Analys & $\mathrm{s}$ \\
ws & is & \\
\hline
\end{tabular}

YES YES YES

1.Promotes core ethical values and supportive performance values as the foundation of good character

2.Defines character comprehensively to include thinking, YES YES YES/NO feeling and behavior

3.Uses a comprehensive, intentional, and proactive approach to character development

4. Creates a caring school community

5. Provides students with opportunities for moral action

6. Includes a meaningful and challenging academic curriculum that respects all learners, develops their character, and helps them to succeed; academic and character intersect

7. Strives to foster students' self- motivation
N/A YES YES/NO

YES YES YES

YES YES N/A

YES YES/ YES

NO

YES YES YES 


\section{Data Sources}

\begin{tabular}{|c|c|c|c|}
\hline $\begin{array}{l}\text { CEP's Effective Principles of } \\
\text { Character Education }\end{array}$ & $\begin{array}{l}\text { Particip } \\
\text { ant } \\
\text { Intervie } \\
\text { ws }\end{array}$ & $\begin{array}{l}\text { Docum } \\
\text { ent } \\
\text { Analys } \\
\text { is }\end{array}$ & $\begin{array}{l}\text { Observation } \\
\mathrm{s}\end{array}$ \\
\hline $\begin{array}{l}\text { 8. Engages the school staff as a learning and moral } \\
\text { community that shares responsibility for character } \\
\text { education and attempts to adhere to the same core values } \\
\text { that guide the education of students }\end{array}$ & NO & YES/ & YES/NO \\
\hline \multirow{2}{*}{$\begin{array}{l}\text { 9. Fosters shared moral leadership and long-range support } \\
\text { of the character education initiative }\end{array}$} & NO & YES/ & YES/NO \\
\hline & & NO & \\
\hline $\begin{array}{l}\text { 10. Engages families and community members as partners } \\
\text { in the character-building effort }\end{array}$ & N/A & YES & $\mathrm{NO}$ \\
\hline $\begin{array}{l}\text { 11. Assesses the character of the school, the school } \\
\text { staff's Functioning as character educators, and } \\
\text { the extent to which students manifest good character }\end{array}$ & NO & NO & NO \\
\hline
\end{tabular}

Note. CEP's Eleven Principles of Effective Character Education, 2007

Yes $=$ found evidence of the principle

$\mathrm{No}=$ No evidence of the principle

$\mathrm{N} / \mathrm{A}=$ did not apply to that data source

$\mathrm{Yes} / \mathrm{No}=$ Evidence was present for some components of the principle but not for others

\section{Summary}

This chapter was divided into three parts. The first section was the description of the definition of character education as expressed by the participants and stated in school documents. The next section was a description of findings presented from the analysis of data sources to determine the method of delivery for the character education curriculum at Taqwa Academy. Based on the principles identified by CEP, the last part of this chapter contained a description of how character education is implemented in the school. The results of this analysis were displayed in Table 9. The last chapter discusses the 
findings and the implications of those findings for Muslim schools. It also discusses recommendations for further research in character education. 


\section{CHAPTER V}

\section{DISCUSSION}

This chapter first discusses the findings concerning how character education was defined at Taqwa Academy. Next it discusses the method of delivery of the character education curriculum in this Muslim school. Then, based on the principles of character education as described by CEP (2007), it discusses how character education is implemented at Taqwa Academy. After discussing the implementation of character education, there is a discussion of the findings and the implications of those findings for Muslim schools. The final section discusses recommendations for further research in character education.

\section{Summary of Findings}

Although the participants of the school defined character education by incorporating similar core values or traits, the definition of character education among the participants varied in process and expected outcome. Findings also revealed that Taqwa Academy had a customized character education initiative that was not a commercially packaged character education program. Instead it was a specific curriculum primarily implemented through the Islamic studies division. This structure represented an add-on delivery method. Despite the separate structure of the character education curriculum, based on participants' expressed experience with the curriculum and informal and formal observations, it was revealed that Taqwa Academy had a partially integrated character education approach. It was partial integration in that some of the core academic classes integrated character education into the curriculum; however integration was not observed in every class. 
The findings also revealed that Taqwa Academy's efforts to teach character education in the operational curriculum was compatible with some of the characteristics identified in the literature by CEP's Eleven Principles of Effective Character Education. The initiatives that are compatible with CEP include promoting core values, creating a caring community, providing students with opportunities for moral action and fostering student self-motivation. However the study also revealed that Taqwa Academy was lacking in the areas of providing professional development for character education to staff and administration. Additionally, the school did not provide a system to assess the progress of the character education initiative in the students, faculty and school, as suggested in the literature by CEP (2007). The findings are discussed according to the research questions in the following section.

\section{Findings}

This section discusses the findings for each research question: How is character education defined at this Muslim school? What method of delivery for the character education curriculum at this Muslim school? How is character education implemented in this Muslim school's curricula? The following discussion begins with the secondary research questions and ends with the major research question: How is character education implemented in this Muslim school?

\section{Defining Character Education}

Character education is complicated, thus making it difficult to define. The definitions of those who attempt to define character education are often a reflection of the implementers values (Otten, 2000). Proponents of character education promote the teaching of character through values or virtues (Hansen, 1995; Lickona, T., 1991; 
Wynne,1997), and usually define character education using virtues or traits such as caring, honesty, respect, and responsibility. Participants at Taqwa Academy, likewise, express their definition of character education using virtues or traits. They use traits such as respect, caring, honesty and politeness. Because the participants' definitions focused on virtues, it appears that their definitions coincided with the psychological theoretical framework for defining character education.

However the definition of character education differed among the participants in the process to instill those traits. This difference in understanding was revealed in the participants' use of intrinsic or extrinsic terms to express their definition of character education. In a qualitative study of character education, Nielsen (2003) found that having a common language enables teachers and students to communicate the definition of good citizenship and the behaviors that demonstrate it. In other words, common language creates the ability to communicate a common understanding. At Taqwa Academy the definitions of character education described by the participants and expressed in the documents are lacking in common language. The differences are noted (a) among participants, and (b) between the participants and the official documents such as the mission statement and the school website. To define character education some participants used intrinsic language, for example, "to inculcate" and "to build," whereas others used extrinsic language such as, "make" or "mold" (see Table 2). The difference in the expression of definition indicates that the implementers of character education at Taqwa Academy are incongruent in their definition of character education. This inconsistency could have an effect on how character education is taught and implemented. For instance, CEP suggests the definition of character should include 
thinking, feeling, and behavior. Teachers who perceive the process of teaching character to be intrinsic may use strategies that include thinking, feeling and behavior because the focus is on the inward development. According to CEP this approach leads to students understanding, appreciating and becoming committed to the core values of the school. On the other hand, teachers who perceive character education as extrinsic may implement strategies that impart information, instead of applying strategies that would achieve understanding and commitment. The common language among participants that defines character will enable faculty to teach character comprehensively.

The description the participants use for accomplishing the desired behavior for character education is also different. Although the participants use traits to describe the expected behavior, the traits that they identify vary among participants. Some participants place emphases on respect, whereas, others emphasize responsibility. In addition, some participants identify specific religious traits such as piety, and God-consciousness as the expected behavior resulting from character education. This difference of expectations could produce confusion for students receiving character education and for participants who are charged with implementing it. As stated by Nielsen (2003), having common language allows the implementers to communicate a definition that demonstrates character education and how it should be implemented. A variety of expected behaviors from a variety of participants could muddle the meaning of character education, thus, derailing the effects of the character education initiatives. The difference in the process and expected behavior expressed in the participants' definitions creates a possible barrier for explicitly communicating the definition of character education among the students and the teachers. 
There is a difference between the participants' expressions of character education and the expression used in the mission statement. The mission statement states the values of the school (Schubert, 1986). Taqwa Academy according to the mission statement values the principles and practices of Islam. However, in their definition for character education, none of the participants at Taqwa Academy used the phrase, "to teach the principles and practices of Islam," although it may have been implied, it was not explicitly stated as it is in the mission statement. Teaching the principles and practices of Islam is comprehensive because it encompasses most of the traits identified by the schools as well as those identified by CEP. By emphasizing individual traits in their description of character education, the participants' definitions are only presenting some of the traits valued by the school. Moreover, to use the phrase "to teach the principles and practices of Islam" in the definition, identifies the religious context in which character education is taught, thus, emphasizing the Muslim identity of the school. The lack of uniformity in participants' definition of character education implies that the participants of Taqwa Academy may not have strategically developed a definition for character education in accordance with the mission statement. This definition could include language that is representative of focus and intent of the school, support the values expressed in the mission statement, and promote the school's identity.

\section{Method of Delivery for Character Education Curriculum at This Muslim School?}

Based on the data collected from the participants' interview responses, and the official documents, as well as from formal and informal observation, it was revealed that the character education curriculum held at Taqwa Academy was add-on and partially 
integrated. The following sections discuss the role of character education in the official and operational curricula.

Official curriculum. The quantity and quality of time dedicated to a task, in this case character education, frame student learning (Schubert, 1986). When a subject is taught and how much time it is given is important for the implementation of a program. If a subject is add-on, it is possible that there are limitations on the time dedicated to its implementation. However, if the subject is integrated into the core subject, there is an indication that the subject is valued by the participants and administrators of the program because it is afforded a place with every core subject. The official curriculum indicated that character education curriculum at Taqwa Academy is primarily an add-on to the curriculum. Evidence from the school's website identified Islamic studies as the avenue through which character education is implemented. The school's website stated:

The Academy maintains focus on its responsibility to guide and assist in building morally strong and healthy personal character of each student...Therefore; the religious programs address best methods to impart educating in[a] manner that ensures acceptance of the knowledge acquired and executing its compliance as the way of life.

The Islamic studies curriculum is separate from the academic curriculum in that both are designated as a separate division with separate leaders and staff members. This suggests that Taqwa Academy's character education program which is delivered through the Islamic studies curriculum is an add-on. Character Education Partnership (2007) referring to an add-on character education curriculum, asserts, "Stand alone' character education programs can be useful first steps or helpful elements of an ongoing effort, but 
are not an adequate substitute for a holistic approach that integrates character development into every aspect of school life'"(p. 1). From a study of successful character education programs, researchers Berkowitz and Bier (2004) identify integrating character education into an academic curriculum as one of the characteristics of a successful character education program. Ryan and Bohlin (1999) also emphasized the importance of integration. They argue:

If we want students to understand virtue, we must teach it. And this does not mean instituting a separate course. Although at the middle and high school level an ethics course can be quite useful, what we are advocating here, for all grades, is the deliberated integration of the concept of virtue into every subject taught. In math, social studies, and even gym, we must tell the human story, our shining moments and our dark ones. (p. 98)

According to these researchers, integrating character education throughout the curriculum is the preferred model for delivering character education (Berkowitz \& Bier, 2004; Ryan \& Bohlin, 1999). At Taqwa Academy, the official curriculum indicates that the role of the character education curriculum is primarily an add-on. Nevertheless, the operational curriculum provides evidence that character education is at least partially integrated in the operating curricula as the following section reveals.

Operational curriculum. Evidence from classroom field notes at Taqwa Academy reveals limited integration of character education. Based on the six principles of integrated character education identified by Rusnak (1998), listed in Chapter 2 of this dissertation, Taqwa Academy has limited evidence of integrated character education. For example, Rusnak (1998) states that integrated character education make it action 
education. At Taqwa Academy there is evidence of teachers applying the pedagogical strategies where students are actively engaged in learning ethical and performance traits through active teaching. An example of the action education was noted during class room observations, where a teacher incorporated cooperative learning and problem-solving in her lesson. CEP (2007) also describes these strategies as active teaching and considers it important to have it in an effective character education program. Another of Rusnak's six principles met by Taqwa Academy includes developing a partnership between school and community. Through grant applications, the Academy reaches out to the community for support in the school's character education efforts. The school also partners with the community in providing community service opportunities for students. Also community members are present for the weekly Jumah prayer and various other activities. Of Rusnak's six principles that Taqwa Academy does not meet, one is empowering teachers. Because teachers at Taqwa Academy do not receive training for character education, they are not empowered to implement the character education initiatives. Consequently, Taqwa Academy does not implement all six of Rusnak's principles that delineate integrated character education. Therefore the method of delivering character education at Taqwa Academy is partially integrated.

\section{Implementation of Character Education at This Muslim School According to Character Education Partnership}

The literature review revealed that a curriculum that teaches character should have formal principles that are indicative of an effective character education curriculum (Berkowitz \& Bier, 2004; Character Education Partnership, 2007). As indicated previously, The Eleven Principles of Effective Character Education (2007) devised by 
Character Education Partnership (CEP) created a framework in which to discuss how the character education was implemented. This framework was used in this study of character education at Taqwa Academy. Data were collected from participants' interview responses, document analysis and formal and informal observations to answer the question of how character education was implemented at this Muslim school. Comparing Taqwa Academy's character education efforts to the principles identified by CEP reveals that Taqwa Academy did not meet all of the criteria of the identified principles. Nonetheless, Taqwa Academy's character education efforts provide evidence that a significant number of the principles of character education are present in the curriculum. The following sections discuss the principles that are present, partially present and those that are absent.

Principles present. Evidence in the three data sources provided show that Taqwa Academy promotes core values, creates a caring school community, provides students with opportunities for moral action and fosters students' self-motivation. The following section discusses the principles within the context of the related literature and Taqwa Academy.

\section{Promotes core ethical values and supportive performance values as the}

foundation of good character. CEP (2007) suggested that schools effectively teach character when ethical and performance based core values are promoted. CEP lists caring, honesty, responsibility, and respect for self-and others as core values (2007). They also list diligence, strong work ethics and perseverance as performance values. Benninga (1997), another promoter of character education, also stresses teaching character through performance values, which include persistence, temperance, and civic mindedness. 
Brogan and Brogan (1999) assert that teaching virtues and excellence is essential for success in education. Taqwa Academy promotes both ethical and performance values as evident in the official curriculum including the Islamic studies and academic curricula as well as the extra-curricular and hidden curriculum. There is evidence to support the promotion of core values found in the official document such as the student and faculty handbooks. Furthermore, the core values are observed in the operational curriculum. For instance, traits such as respect, work ethics, and caring were observed during classroom observations. These findings indicate that Taqwa Academy promotes ethical and performance values in its character education initiatives.

Creates a caring school community. According to CEP (2007), a "school committed to character education becomes a microcosm of a civil, caring and just society" (p.2). Taqwa Academy taught students how to care for others through community service and other gestures of kindness. The literature suggested that serving the community through service projects and activities are effective ways to teach students to care about the community in which they live (Otten, 2000). Taqwa Academy fosters a caring school community by engaging students in community service.

Provides students with opportunities for moral action. A study of character education programs reveals that successful character education programs provide students with opportunities to make meaningful contributions to the school and community (Schwartz, 2005). In addition to providing contributions to the school and community, CEP also asserts that effective character education programs set clear expectations for moral behavior. Not only did Taqwa Academy set clear expectations of moral behavior, they also provide students with opportunities to exercise those behaviors. 
For example, the school supports students who wish to tutor other students by providing a place and time for tutoring. Students are encouraged to self-govern by allowing a place for meetings and providing a sponsor for students. Moral action in the broader community is encouraged by the school providing students with the opportunities to conduct service projects within the community. Students benefit by engaging in activities that allow them to exercise compassion, responsibility and fairness. By providing students with opportunities to make meaningful contributions to the school and community, Taqwa Academy enables students to exercise moral actions.

Strives to foster students' self-motivation. CEP (2007) describes this principle as "doing the right thing when no one is looking" (p.3). Making an effort to foster selfmotivation also requires inspiring students to become better (Ryan \& Bohlin, 1999) Inspiring students could mean stimulating or nurturing the inner spirit to do that which is correct (Tauhidi, 2002). According to CEP (2007) to motivate students, a character education program must include helping students to understand desired behavior and to be aware of the effect of their behavior on others. Knowing why and how behavior affects others assist in teaching self-motivation. Including self-motivation in a character education program, helps students to grow morally (Ryan \& Bohlin, 1999) and assists them in making a transformation as opposed to receiving information (Lickona, 1991). At Taqwa Academy, teachers were observed explaining desired practices and behavior. Students were made aware of how their behavior affected others and they were made to reflect on it. Thus, Taqwa Academic strives to teach self-motivation.

The results of studying six schools that were designated National School of Character Education by CEP, revealed that effective character education programs work. 
Each school in the study included the comprehensive elements central to character education, the core values, and opportunities for moral actions. When compared to nonparticipants, the students participating in these school programs had better attendance, classroom behavior, and grade point average. In addition, they scored 10 point higher on achievement tests (Dovre, 2007). Similarly, as evident in the official and operational curricula, Taqwa Academy, also had those key elements such as promoting ethical and performance values, creating a caring community, providing opportunities for moral action, and fostering self-motivation. The next section presents principles that were partially implemented at Taqwa Academy.

Principles partially present. The following principles were partially implemented. Some principles as described by CEP were comprised of several elements. At times when comparing the school's character education initiatives to CEP's principles the evidence from the school did not support all of the elements of the principle. Thus, the principle was determined to be partially implemented at Taqwa Academy.

\section{Defining "character" comprehensively to include thinking, feeling and}

behavior. In the literature, character is understood as moral personality or the tendency to act in moral ways" (Berkowitz, 1998). At Taqwa Academy students were expected to learn and practice the five pillars of Islam which enabled them to acquire the moral habits, which in turn produced the moral personality that the school sought to produce. According to Berkowitz (1998), without a clear understanding of character, educators will have difficulty designing character education initiatives and teachers will have significant difficulties training students in character education. Taqwa Academy had evidence of all the criteria of this principle except discussion. Although a discussion was 
observed in one class, discussion was not explicitly implemented at all levels in the curriculum. It was not stated in the curriculum nor was it observed at all levels in the classroom. Discussion is an element of thinking, the first part of the definition of character as defined by CEP (2007). According to the literature, class discussion is an essential pedagogical strategy that would allow students to understand the core values taught (Lickona et al, 2007; Romanowski, 2005). Understanding the core values is an important step toward internalizing the core values. Consequently, all of the elements of this principle are not explicitly implemented at all levels in the curriculum; therefore this element was partially implemented.

Uses a comprehensive, intentional, and proactive approach to character. In a review of three studies Swartz (2005) reported that character education programs that work include explicit and ambitious goals for character education, explicit expectations and explicit agenda for character education. The literature suggests that a successful character education initiative engages the thoughts and ideas of the teachers that are used in planning the character education program (Romanowski, 2005). According to CEP (2007), individual teachers, grade-level teams, and staff as a whole should participate in strategic planning for character education. At Taqwa Academy there was no evidence identified in the data collected that strategic planning for character education occurred with individual teachers, grade-level teams or whole staff.

Another element of the comprehensive approach to character education is integration. CEP (2007) suggests that character education should be regularly integrated into the academic content. Integration is considered by researchers as an effective strategy for teaching character (Bulach, 2002; Ryan \& Bohlin, 1999; Sanchez, 2005). 
Timothy Rusnak (1998) identified six principles of an integrated character education program: (a) treating character as a part of every subject (b) making character education action education (c) creating a positive school environment (d) establishing supportive administrative policy and practice, (e) empowering teachers and (f) develop a partnership between school and community. Integrating character education throughout the curriculum was not observed at Taqwa Academy. Thus the principle representing an intentional and proactive approach is partially present in the school's character education initiative at Taqwa Academy.

Includes a meaningful and challenging academic curriculum that respects all learners and develops their character and helps them to succeed. According to CEP (2007), a meaningful and challenging curriculum involves implementing active learning and active teaching methods such as cooperative learning, problem-solving and experience-based projects. Service learning is an example of experience-based projects, which involve students addressing real a community need that is tied to an academic focus (Otten, 2000). Taqwa Academy had evidence that teachers employed cooperative learning, but there were no evidence of service-learning projects implemented at Taqwa Academy. Meaningful and challenging curriculum also involves "fostering a sense of voice and choice give students a say in the decisions and plans that affect them" (CEP, 2007, p.2). The literature reveals that "involving students in decision making affirms intrinsic self-worth and underscores their responsibility as a member of the community" (Power, F.C. (1999). Another element of this principle includes the intersection between academic content and character education. This would mean integrating character education into the every subject as suggested by Rusnak (1998) in his number one 
principle of integration. The evidence that character education is integrated into all of the academic core courses is not evident. The lack of integration could be resulting from the construct of the character education initiative at Taqwa Academy. As indicated in the official curriculum and identified by the participants, it is expected that the Islamic studies department provides the major instructions for character education. This principle was partially implemented at Taqwa Academy.

\section{Engaging families and the community as partners in the character-building}

effort. Berkowitz and Beir (2005) in the study of 33 programs found that effective programs involved family and community in the education of the students' character. In an article, Goodlad (2004) argued that to avoid a caste system in character education, schools should consider the best way to involve parents and others in the character development process. At Taqwa Academy, parents were involved in their child's academic and behavior affairs, but they were not involved in making decisions regarding character education initiatives. Parents' and students' input in the ongoing planning and implementation of character education were the missing element for this principle. Hence, the principle was partially implemented in that parents were involved in the disciplinary aspect of the child, but not in planning and developing a character education initiative.

Engages the school staff as a learning and moral community that shares responsibility for character education and attempts to adhere to the same core values that guide the education of students According to the literature, character education initiatives should have trained staff to implement the program. However, typically, the professional development for character education received the least attention in the 
process of providing character education (Milson \& Mehlig, 2002; Ryan \&Bohlin, 1999).

Taqwa Academy is not the exception. When asked, most teachers at the school stated that they do not receive professional development for character education. The literature reveals that the institutions that are in effect supposed to provide training for teachers to enter the class and teach are not training teachers to implement character education in the classroom (Howard, 2005; O'Sullivan, 2005). Character education training for teachers for pre-service and in-service teachers in most colleges and universities do not exist (Prestwich, 2004). As a result, teachers graduating from education programs are not trained to teach character. Similarly, teachers presently in the classroom were not provided the professional development necessary to teach character.

Despite the lack of evidence to support teacher training at Taqwa Academy in character education, the school implements other elements of this principle. For instance, the staff attempts to adhere to the same core values that guide the education of the students. The evidence reveals that the majority of the faculty at this school are Muslims and they adhere to the same core values that are expected of the students (informal observations). This principle was partially implemented at Taqwa Academy. The next section describes the principles that were not implemented.

Principles not present. Some principles identified by CEP were not implemented at Taqwa Academy. These principles were placed in this category because the elements of the principles were not evident in any of the data sources.

Fosters shared moral leadership and long-range support of the character education initiative. According to CEP (2007), the role of the leader includes sharing the responsibilities of the leadership of character education as well as stressing character 
education as an integral part of the school's mission. In addition, the leader's ability to build consensus among stakeholders in the school is important in developing and maintaining a character education program (DeRoche, 2000; Harned, 1999; Holloway, 2006; Normore \& Quick, 2004). For example, collaborating with participants of the school including teachers, parents, students and community to agree on the values and traditions that the school will implement for character education is to build consensus (DeRoche, 2000; Harned, 1999; Wong, 1998). At Taqwa Academy there is no evidence in the data sources of leader collaboration with other participants to establish or maintain the character education program. When a leader gives voice to the participants of the school, he/she builds a sense of community and trust (Holloway, 2006). There is no evidence of the existence of a character education committee at Taqwa Academy. Based on the evidence, this principle was not implemented at Taqwa Academy

Assesses the character of the school, the school staff's functioning as character educators, and the extent to which students manifest good character. CEP (2007) suggests that there must be an effort to assess student progress in a character education program including qualitative and quantitative methods, considering three areas: (a) the character of the school (b) the school staff's growth as character educators and (c) student character. There is no evidence that Taqwa Academy made assessments in any of the three areas. Although students take tests in the Islamic studies classes, the tests are an evaluation of the student's knowledge of Islamic studies but are not a measurement of character growth. Ryan and Bohlin (1999) posit that assessment should be a priority item at faculty meetings. They also state that there should be discussions and assessments on the school's moral ethos as well as students' internalization of its core virtues. CEP 
(2007) suggests conducting surveys and questionnaires for students and teachers to assess the school's character education program. Taqwa Academy does not have a system in place to measure character education initiatives.

\section{Conclusion}

Taqwa Academy, a private Muslim school in the southeastern region of the United States, strives to educate students to the principles and practices of Islam and to ensure the students' academic success and to make them good citizens, as stated in the mission statement. This study was an attempt to examine how character education was implemented in this Muslim school's curricula. The study reveals that compared to the literature review of the principles of effective character education, Taqwa Academy character education initiatives met most of the requirements for an effective character education curriculum. However, the principles in which the Academy was deficient include: professional development, program assessment, and parental involvement. The literature posits that these missing principles are essential in order to provide an effective character education program (Lickona, et al.,2007; Berkowitz \& Bier, 2004). The fact that Taqwa Academy's character education initiatives met some of the principles and did not met others has implications for the school. The implications are discussed in the following section.

\section{Implications for Muslim Schools}

\section{Defining Character Education}

Berkowitz and Bier (2005) in their research for what works in character education, declared that defining character education is a complicated task. Character education is defined based on the focus and intent of the implementers. The participants 
at Taqwa Academy differed in their descriptions of character education among themselves and from the official documents such as the mission statement and statements on the school's website. This indicates a lack of common process and expected behavioral. These discrepancies have implications for the implementation of the initiative for character education at this school. Lack of common process and expected behavioral may affect how educators teach character, what strategies are used and how they are used, explicitly or implicitly. There are implications for the religious focus of the school. The lack of uniformity in participants' definition of character education also implies that the participants of Taqwa Academy may not have strategically developed a definition in accordance with the school's mission. Additionally, an inconsistency in the perception of defining character education may serve as an obstacle to fully communicating the meaning of character education to the students. According to Nielsen (2003) using a common language to define good citizenship and its behaviors, allows teachers and students to communicate its meaning. Thus, Taqwa Academy's participants defining character education with terms that are consistent with the mission of the school could enhance communications of character education and the expected behaviors that demonstrate it. Perhaps Muslim schools (or religious schools in general) could develop common language to express the definition of character education so participants will have the same terms to communicate the meaning of character education that is accepted and used by the school's community.

\section{Add-on or Integrated}

In religious schools such as the one in this study, the character education curriculum may serve in both roles, add-on or integrated. This implies that schools in this 
situation have an opportunity to create a collaborative working relationship between the religious studies department and the academic department to facilitate the integration of character education and academics. Although in the literature, an add-on character education program is recommended as the first step (CEP, 2007), in this Muslim school the add-on and integrated character education curriculum coexists.

\section{Professional Development}

Professional development for character education is the weakest component in most character education programs, from pre-service teachers to in- service teachers. The few studies that exist regarding teacher preparation for character development suggest that training received or provided for teaching character is minimum (Milson \& Mehlig, 2002). In analyzing the data at this school for characteristics of character education as described by CEP, no evidence was found for professional development. This lack of professional development may well mean that the teachers are not receiving the necessary expertise to implement the character education initiatives of the school. Consequently, this and other schools that lack professional development for character education, could research options for providing professional development for character education for teachers and administrators.

\section{Evaluation}

There was no evidence of formal evaluation for character education in this school. Students were given tests in the Islamic studies classes to test mastery of skills required by the Islamic studies curriculum, such as skills level in the Arabic classes or the knowledge of Islam in the Islamic studies classes or recitation skills and meaning of the Qur'an in the Qur'an classes. However, there was no evidence of an assessment or 
evaluation of character education at this Muslim school. This implies that this school and other religious schools in this situation may not receive the data needed to determine if the curriculum is actually developing students' character; these schools cannot determine the level of any growth in their students. This also suggests that this school and other schools like it are unable to make decisions regarding what does or does not work in their character development initiatives. It also means that they cannot use results for improvement. . The following section discusses the recommendations for further research in character education

\section{Recommendation for Further Research}

Additional research in examining the results of character education is necessary to determine the effectiveness of implementation of character education programs. The following are suggestions for further research:

Develop an instrument to measure character education in religious schools. The instrument used for this study was designed for secular schools and may have missed elements that religious schools may deem valuable, in the case of Taqwa Academy, such elements as God-consciousness and modesty.

Conduct a survey of former students of Muslim schools to gain insight into their character education experience. This study could offer insight into the effectiveness of the character education programs provided by those Muslim School. Research questions to consider are: Are students from Muslim schools internalizing the principles and practices of Islam? Are Muslims who graduate from Muslim schools making contributions to the broader community? How do students who graduate from Muslim schools perceive the experience of attending a Muslim school? Depending on the time 
and resources the researcher could conduct the research using the quantitative method. If time permits, both quantitative and qualitative methods could be applied. The data for this study could be collected through surveys or questionnaires. The questions could focus on their character development and/or Islamic knowledge and practice as it pertains to the schools teaching it.

Conduct a research study on an environment that employs the explicit pedagogical techniques of character education to teach the principles and practices of Islam. This could be a long term study where students receiving this treatment will be followed for 5 years (grades 6-12 th). Again this could vary based on the time and resources. This research would add to the field of character education in determining what pedagogical strategies work for teaching the principles and practices of Islam.

Further research is needed on intrinsic and extrinsic rewards as it relates to developing character. Possible questions to explore are: Which reward system, intrinsic or extrinsic, is better for developing the students' character? Since character development is internal and personal, unlike learning to solve a math problem or reading an article, this research could reveal more about motivating students to internalize desired values.

Additional research could examine assessing character education programs as well as methods of assessing student progress in character education initiatives. In this study, there was no evidence that the school applied an assessment tool to measure character development. CEP suggests that assessment should take place on three levels: student, faculty and school wide. Assessing character education program is an area that could benefit the character education field in that it could expand on the present knowledge for assessing character education. Moreover, assessment could assist 
character education decision making for planning character education initiatives. In addition, an effective assessment instrument is an indication that character education is valued (Lickona, 2004). Assessing character may appear difficult and subjective but with developments made by the Cortland and Character Education Partnership, assessing character education has become less ambiguous and daunting.

Most Muslim Schools strive to develop students' character as well as provide academic excellence, studying character education in Muslim schools could augment Muslim Schools' effort to teach character and lead to beneficial findings for the field of character development. 


\section{REFERENCES}

Ahwee, S., Chiappone, L., \& Cuevas, P. (2004). The hidden and null curriculums: An experiment in collective educational biography. Educational Studies (American Educational Studies Association), 35(1), 25-43.

Algera H. F., \& Sink, C. A. (2002). Another look at character education in Christian schools. Journal of Research on Christian Education, 11(2), 161-81.

Al-Ghazali, M. (2004). Muslim's character. New Delhi, India: Islamic Book Service.

Al-Hamra Academy. (n.d.). About Al-Hamra. Retrieved from http://alhamraacademy.org

Althop, W. \& Berkowitz, M. (2006). Moral education and character education: Their relationship and roles in citizenship education. Journal of Moral Education, 35(4) 495-518.

Anderson, D. (2000). Character education: Who is responsible? Journal of Instructional Psychology, 27(3), 139.

Ankeney, K. (1997).Weaving threads of virtue throughout curriculum. Educational Leadership, 26, 6-7.

Applebee, A. (1974). Tradition and reform in the teaching of English: A history. Urbana, IL: National Council of Teachers of English.

At-Tahan, M. (1999). Perfect Muslim character in the modern world. Cairo, Egypt: ElFalah Foundation.

Badawi, H. (2006). Why Islamic schools? Islamic Horizons, 35(2) 18-27.

Baumrind, D. (2008). Authoritative parenting for character and competence. In D. Streight (Ed.), Parenting for character: Five experts, five practices (pp.17-30). Portland, OR: CSEE Publications.

Benninga, J. S. (1997). Schools, character development, and citizenship. In A. Molnar (Ed.), The construction of children's character: Ninety-sixth yearbook of the national society for the study of education (pp. 77-96). Chicago, IL: University of Chicago Press.

Benninga, J. S., Berkowitz, M.W., Kuehn, P., \& Smith, K. (2006). Character and academics: What good schools do. Phi Delta Kappa International, 87(6), 448452. 
Berkowitz, M. W. (1998). Obstacles to teacher training in character education. Action in Teacher Education, 20(4), 1-10.

Berkowitz, M. W., \& Bier, M. C. (2004). Research-based character education. Annals of the American Academy of Political and social Science, 591, 72-85.

Berkowitz, M. W., \& Bier, M.C. (2006). What works in character education: A researchdriven guide for education. Washington, DC: Character Education Partnership. www.character.org

Berkowtiz, M. (1998). Obstacles to teacher training in character education. Action in Teacher Education, 20(4), 1-10.

Berkowitz, M. W., \& Grych, J. H. (1998). Fostering goodness: Teaching parents to facilitate children's moral development. Journal of Moral Education, 27(3), 371391.

Bogdan, R., \& Biklen, S. K. (2003). Qualitative research in education: An introduction to theory and methods. New York, NY: Allyn and Bacon.

Brogan, B. R., \& Brogan, W. (1999). The formation of character: A necessary goal for success in education. Educational Forum, 63(4), 348-355. Retrieved from http://vnweb.hwwilsonweb.com/hww/rsults/results_single_ftPES,jhtml

Bulach, C. (2002). Implementing a character education curriculum and assessing its impact on student behavior. The Clearing House, 76(2), 79-83.

Center for Advancement of Ethics and Character (CAEC). (n.d). About the CAEC. Retrieved from www.bu.edu./education/caec

Character. (2010). Online dictionary. Retrieved from http://dictionary.reference.com/character

Character Education Partnership (CEP). (2006). Principle 1. Retrieved from www.character.org/principle 1 ? $\mathrm{s}=$ virtues

Character Education Partnership (CEP). (2008). Defining and understanding character education. Retrieved from www.character.org/definingandunderstandingce

Charles E. Smith Jewish Day School. (n.d.). About us. Retrieved from www.cesds.org

Cox, W. F., \& Haney, N. (2002). Analysis of Christian character curricula: Development of holy nation citizens. Journal of Research on Christian Education, 11(2), 12159 .

Cremin, L. (1957). The republic and the school: Horace Mann on the education of free man. New York, NY: Teachers College Press. 
Crescent Academy. (n.d.). About us. Retrieved from www.crescentacademy.org/mission

Creswell, J. W. (1994). Research design: Qualitative and quantitative approaches. Thousand Oaks, CA: Sage.

Culture. (2010). Online dictionary. Retrieved from http://dictionary.reference.com/culture

Davidson, M. \& Lickona, T. (2007). Smart and good: Integrating performance character and moral character in schools. Independent School, 66(2), 24-28.

Deroche, E. (2000). Creating a framework for character education. Principal, 79(3), 3234.

Douglass, S., El-Moslimany, A., \& Uddin, S. (2005, April). Modeling methods for integrated curriculum: Three teaching units. Paper presented at the Islamic Society of North America Education Forum, Chicago, IL.

Dovre, J. (2007). From Aristotle to Angelou: Best practices in character education. Education Next, 7(2), 38-45.

Efron, S. G. (1996). Jewish moral education and character education: A comparison. Journal of Jewish Education, 62, 4-13.

Explicit. (2009). Online dictionary. Retrieved from http://dictionary.reference.com/browse/explicit

Extrinsic. (2009). Online dictionary. Retrieved from http://dictionary.reference.com/browse/extrinsic

Field, S. (1996). Historical perspective on character education. The Educational Forum, $60,118-123$.

Freeman, N. (1998). Morals and character: The foundations of ethics and professional. The Educational Forum, 63(1), 30-36.

Friedman, J. (1996). A Jewish school model for moral education. Journal of Jewish Education, 62, 37-39.

Gibbs, J. (2006). Should Kohlberg's cognitive developmental approach to morality be replaced with a more pragmatic approach? Comments on Krebs and Denton (2005). Psychological Review, 22(3), 666-671.

Goodlad, J. I. (2004). Fulfilling the public purpose of schooling. School Administrator, 61(5), 14-17. 
Greater Boston's Jewish day School. (n.d.). About us. Retrieved from www.cjp.org/dayschools

Grusec, J. E., \& Goodnow, J. F. (1994). Summing up and looking to the future. Developmental Psychology, 30(1), 29-31.

Haneef, S. (2002). What everyone should know about Islam and Muslims.New Delhi India: Islamic Book Service.

Hansen, D. T. (1995).Teaching and the morals of the classrooms. Journal for a Just and Caring Education, 2, 59-74.

Harned, P. (1999). Leading the effort to teach character in schools. NASSP Bulletin, 83, $25-32$.

Hamid, A. (1989). Islam the natural way. London, England: MELS

Hinde, E. R. (2008). Civic education in the NCLB era: The contested mission of elementary and middle schools. Journal of Curriculum and Instruction, 2(1), 7486.

Hoffman, M. L. (1994). Discipline and internalization. Developmental Psychology, 30(1), $26-28$.

Holloway, J. (2006). Model behavior. Principal Leadership, 6(5), 44-48.

Howard, R. W. (2005). Preparing moral educators in an era of standards-based reform. Education Quarterly, 32(4), 43-58.

Iman Academy. (n.d.). About us. Retrieved from www.imanacademy.org/vision statement.html

Implicit. (2009). Online dictionary. Retrieved from http://dictionary.reference.com/browse/implicit

Incidental. (2009). Online dictionary. Retrieved from http://dictionary.reference.com/browse/incidental

Ingalls, C. K. (1999). Jewish teachers and the v-word. Journal of Jewish Education, 62, $29-31$.

Ingalls, C. K. (2002). Pendulum politics: The changing contexts of Jewish moral education. Journal of Jewish Education 68(1), 13-20.

Ingalls, C. K., \& Malkus, M. (2002). Negotiating the borderlands: Implementing an integrated curricular unit in a Jewish day high school. Journal of Jewish Education, 67(1-2), 36-45. 
Intrinsic. (2011). Online dictionary. Retrieved from http://freedictionary.org/?Query=intrinsic

Iqra Academy. (n.d.). About us. Retrieved from http://iqra-academy.org/About.html

Jones, E., Ryan, K., \& Bohlin, K. (1998). Character education and teacher education: How are perspective teachers being prepared to foster good character in students? Action in Teacher Education, 20(4), 11-28.

Josephson, M. (2006). The ethics of American youth: 2006. Retrieved from http://charactercounts.org/programs/reportcard2004/index.html

Kassis, E. T. (1983). A concordance of the Qur'an. Berkeley, CA: University of California Press.

Keyworth, K., \& Ahmed, K. (2009). Islamic schools coming of age. Islamic Horizons, March/April, 32-43.

Kochanska, G. (1994). Beyond cognition expanding the search for the early roots of internalization and conscience. Developmental Psychology, 30(1) 20-22.

Kohlberg, L. (1980). Stages of moral development. In Brenda Munsey (Ed.), Moral development, moral education, and Kohlberg: Basic issues in philosophy, psychology, religion and education (pp.17-98). Birmingham AL: Religious Education Press.

Kohn, A. (1997).The trouble with character education. In A. Molnar (Ed.), The construction of children's character: Ninety-sixth yearbook of the National Society of the Study of Education (pp.154-162). Chicago, IL: University of Chicago Press.

Leming, J. (2000). Tell me a story: An evaluation of a literature-based character education programme. Journal of Moral Education, 29(4), 413-427.

Leming, J. (2001). Historical and ideological perspectives on teaching moral and civic virtue. International Journal of Social Education, 16(1), 62-76.

Lickona, T. (1991). Educating for character: How our schools can teach respect and responsibility. New York, NY: Bantam Books.

Lickona, T. (1993). The return of character education. Educational Leadership, 51(3), 611 .

Lickona, T. (1997). Traditionalist views of character and character education. In A. Molnar (Ed.), The construction of children's character: Ninety-sixth yearbook of 
the National Society of the Study of Education (pp.42-62). Chicago, IL: University of Chicago Press.

Lickona, T. (1999). Character education: The cultivation of virtue. In C. M. Reigeluth (Ed.), Instructional-design theories and models: A new paradigm of instructional theory (pp. 594-612). Mahwah, NJ: Lawrence Erlbaum Associates.

Lickona, T., Schaps, E., \& Lewis, C. (2007). CEP's eleven principles of effective character education. Retrieved from www.character.org

Marshall, C., \& Rossman, G. (1989). Designing qualitative research. Thousand Oaks, CA: Sage Publications, Inc.

Mathison, C. (1998). How teachers feel about character education: A descriptive study. Action in Teacher Education, 20(4), 29-38.

McClellan, B. E. (1999). Moral education in America: School and the shaping of character from colonial times to the present. New York, NY: Teachers College Press.

McKenzie, M. (2004). Seeing the spectrum: North America approaches to emotional, social, and moral education. The Educational Forum 69(1), 79-90.

Metrowest Jewish Day School. (n.d.). History and mission. Retrieved from mwjds.org

Mehra, B. (2001). Research or personal quest? Dilemmas in studying my own kind. In Betty M. Merchant \& Arlette Willis (Eds.), Multiple and intersecting identities in qualitative research (pp.69-82). Mahwah, NJ: Lawrence Erlbaum Associates.

Miles, M., \& Huberman, (1984). Qualitative data analysis: A sourcebook of new methods. Beverly Hills, CA: Sage.

Milson, A. J. (2000). Creating a curriculum for character development: A case study. Clearinghouse, 74(2), 89-93.

Milson, A. J., \& Mehlig, L. (2002). Elementary school teachers' sense of efficacy for character education. Journal of Educational Research, 96(1), 47-53.

Minneapolis Jewish Day School. (n.d.). Mission and vision. Retrieved from www.mjds.net/about_missionVision.asp

Mischel, W., \& Mischel, N. (1976). A cognitive social-learning approach to morality and self-regulation. In T. Lickona (Ed.), Moral development and behavior (pp.84107). New York, NY: Holt, Rinehart and Winston. 
Moore, J. (1991). Adolescent spiritual development. In C. M. Reigeluth (Ed.), Instructional design theories and models: A new paradigm of instructional theory (pp. 613-629). Mahwah, NJ: Lawrence Erlbaum Associates.

Morals. (2010). Online dictionary. Retrieved from http://dictionary.reference.com/morals

Muhammad, Z. (2007). Contributions of the Clara Muhammad Schools to Islamic education and the American society. Muslim Journal, 32(50), 22, 30.

Nadwi, S. (1995). Muhammad the last prophet: A model for all times. United Kingdom: Islamic Academy.

Narvaez, D. (2001). Moral text comprehension: Implications for education and research. Journal of Moral Education, 30(1), 43-54.

Nicgorski, W. (1992). The college experience and character development. Retrieved from http:/www.crvp.org/book/series06/VI-3/chapter_xiii.htm

Nielsen, L. E. (2003). Price laboratory school citizenship program: Qualitative assessment. Journal of Social Studies Research, 27(1), 3-22.

Noddings, N. (1997). Character education and community. In A. Molnar (Ed.), The construction of children's character: Ninety-sixth yearbook of the national society for the study of education (pp. 1-16). Chicago, IL: University of Chicago Press.

Noor Ul-Iman. (n.d.). About NUI:Mission. Retrieved from nuischool.org/index.php

Normore, A., \& Quick, P. (2004). Moral leadership in the 21st century: Everyone is watching - especially the students. Educational Forum, 6(4), 336-347.

O'Sullivan, S. (2005). The soul of teaching: Educating teachers of character. Action in Teacher Education, 26(4), 2-9.

Otten, E.H. (2000). Character education. Eric Clearinghouse for social studies/social science education. Eric Identifier: ED444932. www.eric.ed.gov

Patton, M. Q. (1987). How to use qualitative methods in evaluation. Newbury Park, CA: Sage.

Perry D. G. (1994). Comments on the Grusec and Goodnow model of the role of discipline in moral internalization. Developmental Psychology, 30(1), 23-35.

Power, F., Higgins, A., \& Kohlberg, L. (1989). Lawrence Kohlberg's approach to moral education. New York, NY: Columbia University Press. 
Prestwich, D. L. (2004). Character education in America's schools. The School Community Journal, 14(1),139-150. Retrieved from http://www.adi.org/journal/ss04/Prestiwich.pdf

Purpel, D. (1997). The politics of character education. In A. Molnar (Ed.), The construction of children's character: Ninety-sixth yearbook of the national society for the study of education (pp. 140-153). Chicago, IL: University of Chicago Press.

Qur'an (1980). (Muhammad Asad, Trans.).Al Imran 3:110, Dar Al-Andalus: Gibraltar.

Reagan, T. (2000). Non-western educational traditions: Alternative Approaches to educational Thought and practice. Mahwah, NJ: Lawrence Erlbaum Associates.

Rest, J. R., Narvaez, D., Thomas, S., \& Bebeau, M. (2000). A neo-Kohlbergian approach to morality research. Journal of Moral Education 29(4), 381-395.

Romanowski, M.H., (2005). Through the eyes of teachers: High school teachers' experiences with character education. American Secondary Education 34(1) 6-23.

Roso, C. G. (2004). Character education at a Jewish day school: A case study analysis of a school's curriculum. ProQuest (UMI No. 3122574)

Rusnak, T. (1998). An integrated approach to character education. Thousand Oaks, CA: Sage.

Ryan, K., \& Bohlin, K., (1999). Building character in schools: Practical ways to bring moral instruction to life. Thousand Oaks, CA: Jossey-Bass.

Sanchez, T. (2005). Facing the challenge of character education. International Journal of Social Education, 19(2), 106-111.

Schubert, W. H. (1986). Curriculum: Perspective, paradigm, and possibility. New York, NY: Collier Macmillan Publishers.

Schubert, W. H. (1997). Character education from four perspectives on curriculum. In A. Molnar (Ed.), The construction of children's character: Ninety-sixth yearbook of the national society for the study of education (pp.17-30). Chicago, IL: University of Chicago Press.

Schugurensky, D. (2002). The eight curricula of multicultural citizenship education. Multicultural Education, 10(1), 2-6.

Schwartz, M. J., Beatty, A., \& Dachnowicz, E. (2005). Character education: What is it how does it work, and how effective is it? Retrieved www.character.org/featuredreports 
Shaw, M. (2005, March). Service learning in an Islamic environment. Paper presented at the Islamic Society of North Education Forum, Chicago, IL.

Siddiqi, M. (1993). Hadith literature: Its origin, development and special features. Cambridge, U.K.: The Islamic Text Society.

Silva, D., \& Gimbert, B. (2001). Character education and teacher inquiry: A promising partnership for enhancing children's classrooms. International Journal of Social Education, 16(1), 18-33.

Simon, K. (1998). Bringing it up with the Rabbi: The specialization of moral and spiritual education in a Jewish high school. Journal of Jewish Education, 64(1-2), 33-43.

Simons, L., \& Cleary, B. (2006). The influence of service learning on students' personal and social development. College Teaching, 54(4), 307-319.

Smetana, J. (1999). The role of parents in moral development: A social domain analysis. Journal of Moral Education, 28(3), 311-321.

Stengel, B. S., \& Tom, A. R. (2006). Moral matters: Five ways to develop the moral life of schools. New York, NY: Teachers College Press.

Sternes, B. A. (2006). Don't dumb down character education. The Education Digest, $72(1), 39-43$.

Tauhidi, D. (2002). The Tarbiyah Project. Retrieved from www.tarbiyah.org

Teacher and Mind Resources. (2001-2002). Explicit, implicit and null curricula. Retrieved from http://www.teachermind.com/eisner

Traub, T. (2005). The moral imperative. Education Next, 5(1), 22-33.

Values. (2011). Online dictionary. Retrieved from http://dictionary.reference.com/values

Walker, D. F., \& Soltis, J. F. (1986). Curriculum aims. New York, NY: Teachers College Press.

Weber, C. (1998). Pre-service preparation for teaching character and citizenship: An integrated approach. Action in Teacher Education, 20(4), 85-95.

Wilson, L.O. (2005). What is curriculum? And what are the types of curriculum? Retrieved from www.uwsp.edu/Education/wilson/curric/curtyp.htm

Wong, K. (1998). Culture and moral leadership in education. Peabody Journal of Education, 73(2), 106-25. 
Wren, D. (1999). School culture: Exploring the hidden curriculum. Adolescence, 34, 593-596.

Wynne, E. (1997). For character education. In A. Molnar (Ed.), The construction of children's character The construction of children's character: Ninety-sixth yearbook of the national society for the study of education (pp. 63-76). Chicago, IL: University of Chicago Press.

Yin, R. (1989). Case study research: Design and methods. Thousand Oaks, CA: Sage. 
APPENDICES

Appendix A: Information Letter 


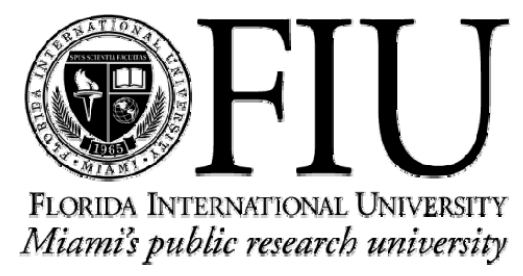

\section{INFORMATION LETTER}

Title: Character Education in a Muslim School: A Case Study of a Comprehensive Muslim School's Curriculum

I, Patricia Salahuddin, a doctoral candidate of the College of Education at Florida International University (FIU), Miami, Florida would like to invite you to participate in a study of character education as it is implemented in a Muslim school. The purpose of this study, which will be used for my dissertation, is to examine how a Muslim school approaches character education in the curriculum. You were selected as a possible participant in this study because of the number of years you have worked in the school. Your years of experience will give insight as to how character education is approached in the school.

Should you decide to participate; an interview will be scheduled at your earliest convenience to gather information regarding your perspectives on character education and how the school approaches it. This project will require one hour of your time, which will be conducted in two 30minute sessions and will be audio taped.

This study presents no risk and requires no cost to you or the school. However, it is the intent that this research will provide participants insight into the development of character education programs in Muslim schools. In a broader sense, the findings in this study will benefit educators in general by adding valuable information to this field of study.

If you decide to participate, participants' confidentiality is important; therefore, precaution will be taken to protect the information given in interviews. Any information that is obtained and connected with this study will be used solely for research purposes. All information will remain confidential. No identifying information will be recorded on the tapes. They will be labeled in coded language and filed in a locked file away from the school. Also, the manuscript will be equally protected in that it will not bare any personal identifying information. The tapes will be erased after the research is completed. The final research will keep the name and location of the school anonymous. A final copy of the research will be available for your review.

You are free to discontinue participation at any time.

For more information and questions, please contact my major professor, Dr. Mohammed Farouk or me. Dr. Farouk can be reached at 305-348-3199 and I can be reached at 305-895-8555 or email at zahirah1@hotmail.com. If you feel that you were mistreated or would like to talk with someone about your rights as a volunteer in this research study you may contact Dr. Patricia Price, the Chairperson of the FIU Institutional Review Board at 305-348-2618 or 305-348-2494.

Sincerely,

Patricia Salahuddin, 
Appendix B: Interview Questions 


\section{INTERVIEW QUESTIONS}

The following semi-structured questions were used to gather data to answer the research questions.

The research question is printed above the set of questions that provided data from the participants of Taqwa Academy.

Research Question: How was character education defined in this Muslim school?

1. In your opinion what is good character?

2. How do you define character education?

3. What core ethical values are taught at this school and how are those values chosen?

Research question: What is the method of delivery for character education?

4. How does the school's mission statement promote character development?

5. In what ways does this school implement the development of students' character?

6. Character education can be delivered as an add-on to the curriculum or integrated throughout the curriculum, which method is employed in this school?

7. This school has religious and academic divisions. What percentage of the responsibility of teaching character is placed on the Islamic studies division and what percentage is placed on the academic division?

Research question: How was character education implemented in this Muslim school? Compared to the Character Education Partnership (2007) characteristics of effective character education

8. How is character development evaluated in this school? (Characteristic \#11-Evaluation)

9. How does professional development training at this school enhance the teachers' ability to teach character? (Characteristic \# 8-professional development)

10. What opportunities are students given to develop character through practical application? (Characteristic \# 5 Opportunity for moral action)

11. How do extra-curricular activities promote character development in this school? (Characteristic \# 3)

12. How is character development promoted through the academic subjects? (integration into academic curriculum (Characteristic \#3)

Probing questions provided participants the opportunity to discuss character education beyond questions asked by researcher

13. Are there any other ways in which the school develops character that we have not already discussed?

14. Complete this sentence: Character development is the responsibility of

Modified from Character Education At A Jewish Day School: A Case Study Analysis of a School's Curriculum by Calvin Gordon Roso. 2004. Dissertation 
Appendix C:

Participants' Definition of Character Education 


\section{Participants' Definition of Character Education}

\begin{tabular}{|c|c|c|c|c|}
\hline \multirow{2}{*}{$\begin{array}{l}\text { Religious } \\
\text { Studies } \\
\text { dept }\end{array}$} & \multirow[t]{2}{*}{ H.H. } & $\begin{array}{l}\text { The means of developing } \\
\text { the character of the }\end{array}$ & & $\begin{array}{l}\text { They are sensitive to the feelings and } \\
\text { needs of others; he is caring, sharing, }\end{array}$ \\
\hline & & $\begin{array}{l}\text { Prencess Shatever values } \\
\text { they are taught into their }\end{array}$ & & $\begin{array}{l}\text { he values and respects others } \\
\text { (expected Behavior) }\end{array}$ \\
\hline \multirow{5}{*}{$\begin{array}{l}3 \text { or less } \\
\text { Yrs } \\
\text { At } \\
\text { The } \\
\text { school }\end{array}$} & J.A. & Treingdo lifach children & & \\
\hline & S.H. & $\begin{array}{l}\text { thlialiaghtething tandes ithe } \\
\text { differeatget tuatiquads a } \\
\text { person in a different angle }\end{array}$ & 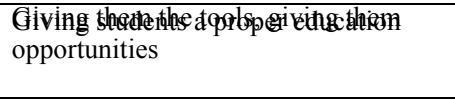 & $\begin{array}{l}\text { Being polite; being respectful, to } \\
\text { peers and teachers; being a good } \\
\text { citizen, being lenient, being soft, and }\end{array}$ \\
\hline & M.S & $\begin{array}{l}\text { blowdif } \oplus \text { fedurateay student } \\
\text { to be a mature and a }\end{array}$ & $\begin{array}{l}\text { Properly supervised and well taken } \\
\text { care of }\end{array}$ & 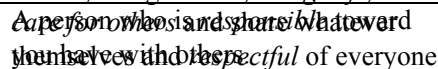 \\
\hline & MW & $\begin{array}{l}\text { resansilhecpessoulues that } \\
\text { the school wants }\end{array}$ & Committed to teach children & $\begin{array}{c}\text { arourfestikgl attitudes beliefs and } \\
\text { behaviors }\end{array}$ \\
\hline & $\begin{array}{l}\text { Parent } \\
\# 1\end{array}$ & $\begin{array}{l}\text { Giving and equation } \\
\text { which helps us to build } \\
\text { outstanding habits that } \\
\text { would be useful for the } \\
\text { rest of our life }\end{array}$ & $\begin{array}{l}\text { [Effectipg togatingingstratepies] } \\
\text { [modeling good character as an } \\
\text { educator] }\end{array}$ & $\begin{array}{l}\text { Piety, selforiscipinime andatef of God } \\
\text { at all times. Sense of guilt when } \\
\text { awareness of God is broken }\end{array}$ \\
\hline \multirow{6}{*}{$\begin{array}{l}\text { More } \\
\text { thram3 } \\
\text { yrs. At } \\
\text { The } \\
\text { school }\end{array}$} & & It is the formation of & & \\
\hline & $\begin{array}{l}\text { Färènt } \\
\# 2\end{array}$ & 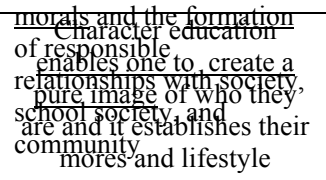 & 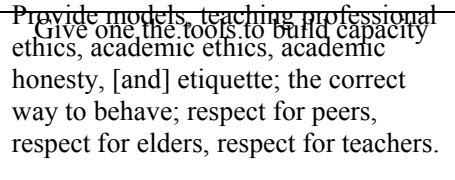 & $\begin{array}{l}\text { A strompseme of seth in addition to } \\
\text { A sernse of empathy in } \\
\text { policies of good conduct }\end{array}$ \\
\hline & & $\begin{array}{l}\text { Intrinsic terms: input } \\
\text { into, formation, build in, } \\
\text { inculcate, help us to build, }\end{array}$ & $\begin{array}{l}\text { Extrinsic terms: teach (2), making(2), } \\
\text { guidance, molding, integrate in } \\
\text { subject, leads, }\end{array}$ & $\begin{array}{l}\text { Religious terms: Boldfaced } \\
\text { Secular terms: Italicized }\end{array}$ \\
\hline & F.Q. & 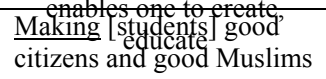 & & \\
\hline & M.R. & $\begin{array}{l}\text { Guidance of the students, } \\
\text { molding them into what } \\
\text { they should be }\end{array}$ & $\begin{array}{l}\text { Etiquette, getting along with peers, } \\
\text { teachers, and anyone in society }\end{array}$ & \\
\hline & Q.I & $\begin{array}{l}\text { To make a person a better } \\
\text { person in the sight of God. }\end{array}$ & The objective of education & $\begin{array}{l}\text { Obligation to Allah } \\
\text { Fulfill personal obligations to } \\
\text { Allah...like praying, fasting, and hajj; } \\
\text { refrain from the evil things like } \\
\text { profanity, drugs, alcohol, and stealing. } \\
\text { Obligations to society } \\
\text { See himself as part of the human race; } \\
\text { sent as the Khalifa (caregiver, leader) } \\
\text { as God's representative to do God's } \\
\text { work }\end{array}$ \\
\hline \multirow[t]{3}{*}{ Admin } & F.K. & $\begin{array}{l}\text { It is a long process to build } \\
\text { certain skills in the } \\
\text { children...bring deen (way } \\
\text { of life) into the students' } \\
\text { life and build ethical } \\
\text { character in the life of the } \\
\text { children. }\end{array}$ & $\begin{array}{l}\text { Build trust in the student.. You have to } \\
\text { bring the love of the deen in students. } \\
\text { [provide the right environment] }\end{array}$ & [See a change in student behavior] \\
\hline & M.M. & $\begin{array}{l}\text { Something that is } \\
\text { integrated in all aspects of } \\
\text { subject area and it is } \\
\text { modeled by instructor, } \\
\text { administrator, and the } \\
\text { campus and committee } \\
\text { members. }\end{array}$ & $\begin{array}{l}\text { Taught in the classroom and outside of } \\
\text { the classroom...modeled by the adult } \\
\text { role models and is corrected in the } \\
\text { students' daily activities... draw } \\
\text { students back to expectations- } \\
\text { [religious or social] }\end{array}$ & $\begin{array}{l}\text { Considerate of fellow brother; looking } \\
\text { at the communal aspect with the } \\
\text { social order of things and not } \\
\text { forgetting the individual rights }\end{array}$ \\
\hline & C.S. & & & \\
\hline
\end{tabular}


This chart displayed the definition of character education as it is expressed by the participants of the school.

After analyzing the parts of definition for focus or intent, terms indicating instilling or internalizing was labeled intrinsic and the opposite was labeled extrinsic. From the expression of the desired outcome (Intent) religious or secular reference were the two categories to label these term. 
Appendix D:

Curriculum Benchmarks Related to

Character Education: Social Studies 


\begin{tabular}{|c|c|c|c|c|}
\hline \multirow{2}{*}{$\begin{array}{l}\text { Social } \\
\text { Studies }\end{array}$} & 3rd Grade & 6th Grade & 8th Grade & 9-12th Grades \\
\hline & $\begin{array}{l}\text { Recognize rules } \\
\text { in school such as } \\
\text { respecting others. } \\
\text { SS.3.c.1.Pa.a } \\
\text { Recognize the } \\
\text { rules and laws in } \\
\text { school and } \\
\text { community such } \\
\text { as to promote } \\
\text { safety, order, } \\
\text { good citizenship. } \\
\text { SS.3.C.1. Su.a } \\
\text { Identify actions } \\
\text { of citizens that } \\
\text { contribute to the } \\
\text { community, such } \\
\text { as respecting } \\
\text { property, helping } \\
\text { neighbors, and } \\
\text { participating in } \\
\text { community } \\
\text { actions. } \\
\text { SS.3C.2.In.a }\end{array}$ & $\begin{array}{l}\text { Describe how } \\
\text { history } \\
\text { transmits } \\
\text { culture and } \\
\text { heritage and } \\
\text { provides models } \\
\text { of human } \\
\text { character. } \\
\text { SS.6.w.1.6 }\end{array}$ & $\begin{array}{l}\text { Examine the } \\
\text { aspects of slave } \\
\text { culture including } \\
\text { plantation life } \\
\text { resistance efforts, } \\
\text { and the role of the } \\
\text { slaves' spiritual } \\
\text { system. } \\
\text { SS.A.4.1.1 } \\
\text { Recognize the } \\
\text { role of civic } \\
\text { virtue in the lives } \\
\text { of citizens and } \\
\text { leaders from the } \\
\text { colonial period } \\
\text { through } \\
\text { reconstruction. } \\
\text { SS.8.C.1.3 }\end{array}$ & $\begin{array}{l}\text { 13th 14th, 15th } \\
\text { Amendments to the } \\
\text { constitution and } \\
\text { guaranteed freedom } \\
\text { SS.912.A.2.4 } \\
\text { Jim Crow laws } \\
\text { SS.912.A.2.5 } \\
\text { Black codes and the } \\
\text { Nadir SS.912.A.2.6 } \\
\text { Native American } \\
\text { experience. } \\
\text { SS.912.A.2.7 } \\
\text { Analyze the use of } \\
\text { atomic weapons } \\
\text { SS.912.A.6.6 } \\
\text { SS.912.A.7.2. } \\
\text { Analyze ideas and } \\
\text { principles of the } \\
\text { founding document that } \\
\text { shaped American } \\
\text { Demoracy.SS.912.C.1.3 } \\
\text { The public good } \\
\text { SS.912.C.2.4 } \\
\text { Conduct a service } \\
\text { project to further the } \\
\text { public } \\
\text { good.SS.912.C.2.5 }\end{array}$ \\
\hline
\end{tabular}


Appendix E:

Curriculum Benchmarks Related to

Character Education: Reading/Language Arts 
State Standards Related to Character Education: Language Arts Curriculum

\begin{tabular}{|c|c|c|c|c|}
\hline \multirow{4}{*}{$\begin{array}{l}\text { Reading/Language } \\
\text { Arts }\end{array}$} & 3rd Grade & 6th Grade & 8th Grade & 9-10th Grades \\
\hline & None found & $\begin{array}{l}\text { Recurring themes } \\
\text { (bravery, friendship, } \\
\text { loyalty, good vs. } \\
\text { evil) LA.6.2.1.4 } \\
\text { Explain how ideas, } \\
\text { values and themes of } \\
\text { a literary work often } \\
\text { reflect the historical } \\
\text { period in which it } \\
\text { was written } \\
\text { LA.6.2.1.9 } \\
\text { Understand the } \\
\text { importance of ethical } \\
\text { research LA.6.6.2.4 } \\
\text { Ethical use of media }\end{array}$ & $\begin{array}{l}\text { Explain how } \\
\text { ideas, values and } \\
\text { themes of a } \\
\text { literary work } \\
\text { reflect historical } \\
\text { period in which } \\
\text { it was written. } \\
\text { LA.6.2.1.8 } \\
\text { Expanding core } \\
\text { knowledge as a } \\
\text { literate member } \\
\text { of a shared } \\
\text { society culture } \\
\text { LA.8.1.1.0 } \\
\text { Legal and ethical } \\
\text { practices } \\
\text { LA.8.6.2.4 }\end{array}$ & $\begin{array}{l}\text { Explain how ideas, } \\
\text { values and themes } \\
\text { of a literary work } \\
\text { often reflect } \\
\text { historical period in } \\
\text { which it was } \\
\text { written. } \\
\text { LA.910.2.1.8 } \\
\text { Expanding core } \\
\text { knowledge as a } \\
\text { literate member of } \\
\text { a shared society } \\
\text { culture } \\
\text { LA.910.2.1.0 } \\
\text { Understand the } \\
\text { importance of } \\
\text { legal and ethical } \\
\text { practice } \\
\text { LA.910.6.2.4 } \\
\text { Propaganda and } \\
\text { ethical reasoning } \\
\text { strategies in print } \\
\text { and non-print } \\
\text { media. LA } \\
\text { 910.6.3.1 } \\
\text { Ethical use mass } \\
\text { media LA } \\
\text { 910.6.3.2 }\end{array}$ \\
\hline & & & & 11-12 Grades \\
\hline & & & & $\begin{array}{l}\text { Understand the } \\
\text { importance of } \\
\text { legal and ethical } \\
\text { practice } \\
\text { LA.1112.6.2.4 } \\
\text { Distinguish } \\
\text { between } \\
\text { Propaganda and } \\
\text { ethical reasoning } \\
\text { strategies in print } \\
\text { and non-print } \\
\text { media. LA } \\
1112.6 .3 .1 \\
\text { Ethical use mass } \\
\text { media and digital } \\
\text { technology in } \\
\text { assignments and } \\
\text { presentations LA } \\
1112.6 .3 .2\end{array}$ \\
\hline
\end{tabular}


Appendix F:

Curriculum Benchmarks Related to

Character Education: Science 
State Standards Related to Character Education: Science Curriculum

\begin{tabular}{|c|c|c|c|c|}
\hline \multirow[t]{2}{*}{ Science } & $3^{\text {rd }}$ Grade & $6^{\text {th }}$ Grade & $8^{\text {th }}$ Grade & 9-12th Grades \\
\hline & $\begin{array}{l}\text { None } \\
\text { found }\end{array}$ & $\begin{array}{l}\text { None } \\
\text { Found }\end{array}$ & $\begin{array}{l}\text { Explain how } \\
\text { political, social and } \\
\text { economic concerns } \\
\text { can affect science, } \\
\text { and vice versa } \\
\text { (discuss the ethical } \\
\text { implication of this } \\
\text { influence) SCN.4.2 }\end{array}$ & $\begin{array}{l}\text { Evaluate the } \\
\text { impact of bio } \\
\text { technology on } \\
\text { the individual } \\
\text { society and the } \\
\text { environment } \\
\text { including } \\
\text { medical and } \\
\text { ethical issues. } \\
\text { SC.912.L.1.61.0 }\end{array}$ \\
\hline
\end{tabular}


Appendix G:

Islamic Studies Curriculum 
RELIGIOUS STUDIES

$\underline{\text { Islamic Studies Curriculum }}$

\begin{tabular}{||l|l||}
\hline Course Title & Islamics I \\
\hline \hline Grade & $9-12$ \\
\hline \hline Pre-Requisite & None \\
\hline \hline Credit & 1 \\
\hline \hline Class Size & - \\
\hline \hline Availability & Every Year \\
\hline \hline \multicolumn{1}{|c|}{ Islamics I } & Introduces the student to the \\
& basic beliefs of a Muslim. The \\
& fundamental pillars of Islam \\
& (i.e.: shahada: declaration of \\
faith; salaah: the five prayers; & zakaah: the paying of alms; \\
& siyam: fasting; and hajj: \\
& pilgrimage) are explored. \\
\hline
\end{tabular}

\begin{tabular}{|c|c|}
\hline Course Title & Islamics II \\
\hline Grade & $9-12$ \\
\hline Pre-Requisite & Islamics 1 \\
\hline Credit & 1 \\
\hline Class Size & - \\
\hline Availability & Every Year \\
\hline Islamics II & $\begin{array}{l}\text { Involves an in-depth study of the } \\
\text { various characters mentioned in } \\
\text { the Quran and how they were } \\
\text { able to affect people's lives both } \\
\text { positively and negatively. } \\
\text { Attention is paid to its } \\
\text { application in the lives of } \\
\text { students. The student will } \\
\text { develop a clear understanding of } \\
\text { the life, ministry, and teachings } \\
\text { of Prophet Muhammad (peace }\end{array}$ \\
\hline
\end{tabular}




\begin{tabular}{||c||c||}
\hline & $\begin{array}{c}\text { be upon him). Students will also } \\
\text { memorize and study the } \\
\text { implication of selected passages } \\
\text { from the Quran with the } \\
\text { objective of internalizing that } \\
\text { knowledge. }\end{array}$ \\
\hline
\end{tabular}

\begin{tabular}{|c|c|}
\hline Course Title & Islamics III \\
\hline Grade & $9-12$ \\
\hline Pre-Requisite & Islamics II \\
\hline Credit & 1 \\
\hline Class Size & - \\
\hline Availability & Every Year \\
\hline Islamics III & $\begin{array}{l}\text { Allows the students to explore } \\
\text { the primary and secondary } \\
\text { sources of Islamic Law, viz.: } \\
\text { Quran, Sunnah/Hadith, Qiyas, } \\
\text { Ijmaa', etc. Emphasis is placed } \\
\text { on the origin, transmittance, } \\
\text { compilation, and application of } \\
\text { the two primary sources. } \\
\text { Students will also memorize and } \\
\text { study the implication of selected } \\
\text { passages from the Quran with } \\
\text { the objective of internalizing that } \\
\text { knowledge. } \\
\text { The different sects and schools } \\
\text { are investigated and their impact } \\
\text { on Islam from within and } \\
\text { beyond the Muslim community. }\end{array}$ \\
\hline
\end{tabular}

\begin{tabular}{||l|l||}
\hline Course Title & Islamics IV \\
\hline \hline Grade & $9-12$ \\
\hline \hline Pre-Requisite & Islamics III \\
\hline \hline Credit & 1 \\
\hline \hline Class Size & - \\
\hline \hline Availability & Every Year \\
\hline \hline
\end{tabular}




\begin{tabular}{||l||c||}
\hline Islamics IV & Focuses on different sociological \\
& views on origins of the universe; \\
& various worldviews and schools of \\
& thought affecting current attitudes \\
& toward Islam and the Muslims are \\
& discussed. Its purpose is to prepare \\
& Muslim students for interaction \\
& with a secular environment. \\
\hline
\end{tabular}

\begin{tabular}{|l|l||}
\hline Course Title & Islamics V \\
\hline \hline Grade & 9-12 \\
\hline \hline Pre-Requisite & Islamics IV \\
\hline \hline Credit & 1 \\
\hline \hline Class Size & - \\
\hline \hline Availability & Every Year \\
\hline \hline \multicolumn{1}{||c|}{ Islamics V } & Provides the opportunity for \\
& students to analyze various Islamic \\
& role models and their effect upon \\
& societies in which they lived. \\
& Students will also view current \\
& world awareness topics from an \\
& Islamic perspective; compare \\
& religions from the basis of origin \\
& and understand how they have \\
& impacted the lives of the great \\
& multitude of believing men and \\
& women throughout history; and \\
& recognize that in spite of religious \\
& differences, they should be \\
& respectful to all and work in pursuit \\
of the development of their \\
community and society as a whole. \\
\hline
\end{tabular}


VITA

\section{PATRICIA ZAHIRAH SALAHUDDIN}

1971

1980-1986

1986-Present

1988

2003-2011
Bachelor of Science Mississippi State University Starkville, Mississippi

Girl Scouts of America

English Teacher

Dade County Public Schools

Miami, Florida

Masters in Public Administration

Florida International University

Miami, Florida

Doctorate in Education

Florida International University

Miami, Florida

\section{PUBLICATIONS and PRESENTATIONS}

Salahuddin, P. (2005). Islam in the American classroom. In S. Nielsen, M. Plakhotnik \& T. Rocco (Eds.), Proceedings of the Fourth Annual College of Education Conference [Compact Disk]. Miami, FL: Florida International University.

Salahuddin, P. (2009). Principles and characteristics of character education: An approach to internalizing Islamic values. Paper presented at the $10^{\text {th }}$ Annual ISNA Education Forum on Celebrating a Decade of Leadership Preserving the Legacy, Shaping the Future. Online at http://www.isna.net/Documents/Programs/PaperssubmittedforEF09final.pdf

Salahuddin, P. (2005). Literary arts and social conflict. Presented at the $95^{\text {th }}$ National Council Teachers of English Conference on On Common Ground, Pittsburgh, Pennsylvania.

Salahuddin, P. (2007). Internalizing Islamic principles: Character education in Islamic schools. Paper presented at Islamic Schools League of America Leadership Conference in collaboration with the Graduate School of Islamic \& Social Sciences, Georgetown University, Dulles, Virginia.

Salahuddin, P. (2008). Empowering tomorrow's leaders. Paper presented at the Ninth Annual ISNA Education Forum on Sustaining Progress: Cultivating Stewardship, Rosemont, IL. 